\title{
ARTICLE
}

\section{Cancer cell CCR2 orchestrates suppression of the adaptive immune response}

\author{
Miriam R. Fein ${ }^{1,2 *}$ (D), Xue-Yan He ${ }^{1 *}$, Ana S. Almeida ${ }^{1}$ (D), Emilis Bružas ${ }^{1,3}$ (D), Arnaud Pommier ${ }^{1}$, Ran Yan ${ }^{1,3}$ (D), Anaïs Eberhardt ${ }^{1,4}$, Douglas T. Fearon ${ }^{1,5,6}$ (D), \\ Linda Van Aelst ${ }^{1}$ D, John Erby Wilkinson ${ }^{7}$ (D) Camila O. dos Santos ${ }^{1}$ (D), and Mikala Egeblad ${ }^{1}$ (D)
}

\begin{abstract}
C-C chemokine receptor type 2 (CCR2) is expressed on monocytes and facilitates their recruitment to tumors. Though breast cancer cells also express CCR2, its functions in these cells are unclear. We found that Ccr2 deletion in cancer cells led to reduced tumor growth and approximately twofold longer survival in an orthotopic, isograft breast cancer mouse model. Deletion of Ccr2 in cancer cells resulted in multiple alterations associated with better immune control: increased infiltration and

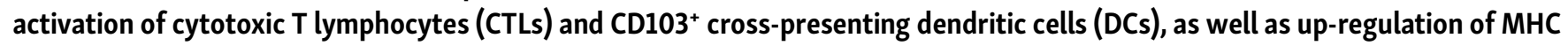
class I and down-regulation of checkpoint regulator PD-L1 on the cancer cells. Pharmacological or genetic targeting of CCR2 increased cancer cell sensitivity to CTLs and enabled the cancer cells to induce DC maturation toward the CD103+ subtype. Consistently, $\mathrm{Ccr}^{-/-}$cancer cells did not induce immune suppression in Batf3 $3^{-/-}$mice lacking $\mathrm{CD}_{103^{+}} \mathrm{DCs}$. Our results establish that CCR2 signaling in cancer cells can orchestrate suppression of the immune response.
\end{abstract}

\section{Introduction}

Tumors escape immune control via multiple mechanisms (Dunn et al., 2002, 2004). These mechanisms include cancer cellintrinsic changes that alter how the cancer cell is recognized by the immune system and extrinsic changes that suppress immune cell activities. For example, cancer cells can intrinsically decrease the surface expression of MHC class I, making them effectively invisible to cytotoxic T lymphocytes (CTLs; Garrido et al., 2016). Moreover, cancer cells can up-regulate programmed cell death ligand 1 (PD-L1/B7-H1), which binds the PD-1 receptor on activated $\mathrm{T}$ cells, resulting in $\mathrm{T}$ cell anergy, ultimately protecting cancer cells against $\mathrm{T}$ cell-mediated killing (Chen et al., 2016a). Extrinsic mechanisms include the down-regulation of costimulatory molecules (e.g., CD86) on antigen-presenting cells; the secretion of cytokines that directly inhibit CTLs; and the recruitment of regulatory $\mathrm{T}$ cells and myeloid-derived suppressor cells (MDSCs; Igney and Krammer, 2002). In contrast, infiltration of $\mathrm{CD}_{103}{ }^{+}$dendritic cells (DCs) in mice, phenotypically similar to $\mathrm{CD}_{141^{+}} \mathrm{DCs}$ in humans (Hildner et al., 2008), has emerged as a mechanism by which tumors may be kept under immune control. $\mathrm{CD}_{103^{+}} \mathrm{DCs}$ are highly efficient at acquiring and processing exogenous antigens, which they directly present on MHC class I molecules to CD8 ${ }^{+}$CTLs. Even a modest accumulation of $\mathrm{CD}_{103}{ }^{+} \mathrm{DCs}$ in tumors has been associated with improved immune-mediated tumor control (Broz et al., 2014; Roberts et al., 2016).

Chemokine receptors mediate the recruitment of immune cells to sites of inflammation and to tumors. C-C chemokine receptor type 2 (CCR2) is expressed by several bone marrowderived cell types (including inflammatory monocytes, myeloid precursor cells, and immature DCs), as well as B and T lymphocytes (Lim et al., 2016). CCR2-expressing cells are recruited to sites of inflammation primarily by C-C chemokine ligand 2 (CCL2; Deshmane et al., 2009), although other CCL family members also can activate CCR2. Chemotherapy treatment promotes CCR2-dependent infiltration of tumor-promoting myeloid cells to murine mammary tumors (Nakasone et al., 2012), and CCL2/CCR2-mediated recruitment of CCR2' inflammatory monocytes to the lung has been shown to promote breast cancer extravasation and metastasis in mouse models (Qian et al., 2011). Furthermore, elevated levels of CCL2 in tumors and in serum are associated with advanced disease and poor prognosis in breast carcinoma patients (Lebrecht et al., 2004, 2001; Soria and BenBaruch, 2008). These findings have sparked interest in targeting the CCR2 pathway to modulate the innate immune response for

${ }^{1}$ Cold Spring Harbor Laboratory, Cold Spring Harbor, NY; ${ }^{2}$ Graduate Program in Genetics, Stony Brook University, Stony Brook, NY; ${ }^{3}$ Watson School of Biological Sciences, Cold Spring Harbor, NY; ${ }^{4}$ Département de Biologie, École Normale Supérieure de Lyon, Lyon, France; ${ }^{5}$ Cancer Research UK Cambridge Institute, University of Cambridge, Li Ka Shing Centre, Cambridge, UK; ${ }^{6}$ Weill Cornell Medical College, New York, NY; ${ }^{7}$ Departments of Molecular and Integrative Physiology and Internal Medicine, University of Michigan, Ann Arbor, MI.

${ }^{*}$ M.R. Fein and X.-Y. He contributed equally to this paper; Correspondence to Mikala Egeblad: egeblad@cshl.edu; A.S. Almeida's present address is APC Microbiome and School of Microbiology, University College Cork, Cork, Ireland.

(C) 2020 Fein et al. This article is distributed under the terms of an Attribution-Noncommercial-Share Alike-No Mirror Sites license for the first six months after the publication date (see http://www.rupress.org/terms/). After six months it is available under a Creative Commons License (Attribution-Noncommercial-Share Alike 4.0 International license, as described at https://creativecommons.org/licenses/by-nc-sa/4.0/). 
therapeutic benefit in cancer. However, CCR2 is also expressed by breast cancer cells, and activation of CCR2 by CCL2 can induce cancer cell migration and survival through Smad3-, p42/ 44MAPK-, and Rho guanosine triphosphatase-mediated signaling (Fang et al., 2012). In vivo, the potential roles of CCR2 signaling in cancer cells have not been well investigated, largely because they were thought to be minor compared with the roles of CCR2 in myeloid cells.

In this study, we report that CCR2 signaling in cancer cells plays a surprisingly major role in regulating the immune response to murine breast tumors. We show that CCR2 in cancer cells supports immune escape by inhibiting $\mathrm{CD}_{103^{+}} \mathrm{DC}$ infiltration and maturation and by suppressing CTL activity. CCR2 expression on cancer cells represents a previously uncharacterized mechanism for immune suppression. Thus, our data support the notion that the CCL2/CCR2 axis is an important immune modulatory pathway in cancer, used by both immune cells and cancer cells to orchestrate immune suppression.

\section{Results}

CCR2 in cancer cells promotes primary tumor growth in an orthotopic, isograft breast cancer mouse model

To investigate the potential effects of CCR2 on breast tumor growth and metastasis, we crossed $\mathrm{Ccr}^{-/-}$mice (Boring et al., 1997) with mouse mammary tumor virus-polyoma middle $T$ (MMTV-PyMT) mice, a model of luminal B breast cancer (Guy et al., 1992; Lin et al., 2003). The Ccr2 genotype did not influence normal mammary gland development (Fig. S1 A) or tumor onset (Fig. 1 A); however, loss of even one allele of Ccr2 significantly reduced tumor growth rates (Fig. 1 B). Consistently, survival time was significantly longer for the MMTV-PyMT;Ccr2 ${ }^{-/-}$and MMTV-PyMT;C Cr2 ${ }^{+/-}$mice compared with that of the MMTVPyMT;CCr2 ${ }^{+/+}$mice (Fig. $1 \mathrm{C}$ ). In addition, we noted that the tumors of MMTV-PyMT;CCr2 ${ }^{-/-}$and MMTV-PyMT;CCr2 ${ }^{+/-}$mice were more cystic, with reduced solid areas, than those of MMTV-PyMT;Crr2 ${ }^{+/+}$mice (Fig. S1, B and C).

The importance of CCR2 signaling for monocyte recruitment is well understood, but CCR2 is also expressed by human breast cancer cells (Fang et al., 2012). In accordance with this report, we detected Ccr2 mRNA and CCR2 protein in the cancer cells of the tumors developing in MMTV-PyMT;CCr2 ${ }^{+/+}$mice (Fig. 1, D and $\mathrm{E}$ ), and using RNA fluorescence in situ hybridization (FISH), we demonstrated that Ccr2 mRNA is expressed by Krt18-positive breast cancer cells (Fig. S1 D). To determine the relative contributions of cancer cell versus host CCR2 to tumor growth, we isolated primary cancer cells (purity $>90 \%$; Fig. S1 E) from MMTV-PyMT;CCr2 ${ }^{+/+}$and MMTV-PyMT;C Cr2 ${ }^{-/-}$mice and transplanted them orthotopically to mammary glands of either $\mathrm{CCr}^{+/+}$ or $\mathrm{Crr}^{-/-}$syngeneic host mice (Fig. $1 \mathrm{~F}$ ). Loss of C cr2 in the host did not alter tumor growth, consistent with our previous report (Nakasone et al., 2012). However, loss of Ccr2 in cancer cells significantly reduced tumor growth rates, leading to approximately twofold longer survival (Fig. 1, G and H). Ccr2 mRNA levels of $\mathrm{Ccr2}^{+/-}$cancer cells were lower than those of $\mathrm{Ccr}^{+/+}$cancer cells (Fig. S1 F), and tumors derived from $\mathrm{Ccr}^{+/-}$cancer cells exhibited the same slow growth as tumors derived from $\mathrm{Crr}^{-/-}$ cancer cells (Fig. S1 G). This result suggests that a threshold level of CCR2 expression in MMTV-PyMT cancer cells regulates tumor growth.

$\mathrm{CCR}^{+}$inflammatory monocytes can promote breast cancer metastasis (Müller et al., 2001; Qian et al., 2011). The overall metastatic burden in the lung - the primary site of metastasis in the MMTV-PyMT model-was, however, very variable in MMTV-PyMT;CCr2 ${ }^{+/+}$mice and was not significantly different from that of MMTV-PyMT;C Cr2 ${ }^{-/-}$mice (Fig. S1 H). There were also no significant differences in the number of metastatic foci (representing seeding density) related to the Ccr2 genotype (Fig. S1 I). However, we found that the metastatic foci were larger in the lungs of MMTV-PyMT;C Cr2 ${ }^{+/+}$mice than in the lungs of MMTV-PyMT;Ccr2 ${ }^{-/-}$mice (Fig. S1 J), suggesting that CCR2 promotes the growth of secondary lesions.

\section{Ccr2 expression in cancer cells is associated with poor differentiation and reduced apoptosis sensitivity}

The tumors from transplanted $\mathrm{Ccr}^{+/+}$or $\mathrm{Ccr}^{-/-}$cancer cells were markedly different at the histological level (Fig. $2 \mathrm{~A}$ ), similar to the autochthonous tumors in the MMTV-PyMT;CCr2 ${ }^{-/-}$animals (Fig. S1, $\mathrm{B}$ and $\mathrm{C}$ ). The tumors originating from $\mathrm{Ccr}^{+/+}$cancer cells consisted entirely of microlobules composed of sheets of large, neoplastic epithelial cells. The microlobules were surrounded by small amounts of fibrovascular stroma containing dense collagen, which is characteristic of poorly differentiated MMTV-PyMT tumors. The neoplastic cells had round-to-oval nuclei, prominent nucleoli, scant cytoplasm, and indistinct cell borders, typical of undifferentiated cells. In contrast, the tumors originating from $\mathrm{Cr} 2^{-/-}$cancer cells were more differentiated. In many areas, the cancer cells contained lipid vacuoles of various sizes. These tumors also had large cystic areas lined by a single or double layer of small, polarized epithelial cells, and the lumina were filled with proteinaceous secretions (Fig. $2 \mathrm{~A}$ ). Conversely, the tumors originating from $\mathrm{Ccr}^{-/-}$cancer cells had a reduced percentage of solid areas compared with those originating from $\mathrm{Ccr}^{+/+}$cancer cells (Fig. $2 \mathrm{~B}$ ).

To understand why tumors from $\mathrm{Ccr}^{-/-}$cancer cells grew more slowly than tumors from $\mathrm{Ccr}^{+/+}$cancer cells, we next examined the rates of proliferation and apoptosis in the tumors collected during the phase when $\mathrm{Ccr} 2^{-1-}$ tumors were growth restricted, 5-6 wk after transplantation. There was no difference in proliferation as determined by nuclear Ki67 staining (Fig. 2 $\mathrm{C}$ ), and primary $\mathrm{Ccr2}^{+/+}$and $\mathrm{Cr} 2^{-/-}$cancer cells also grew similarly in vitro (Fig. 2 D). However, we found a higher percentage of cancer cells undergoing apoptosis in tumors from $\mathrm{Ccr}^{-/-}$ cancer cells than from $\mathrm{Ccr}^{+/+}$cancer cells (Fig. $2 \mathrm{E}$ ). Furthermore, $\mathrm{Crr} 2^{-/-}$cancer cells were more sensitive to serum-free conditions (Fig. 2 F), consistent with a previous study showing that CCR2 signaling can protect cancer cells from apoptosis induced by serum starvation (Fang et al., 2012).

\section{$\mathrm{Ccr2}^{-1-}$ cancer cells have increased expression of interferon (IFN) response genes and of genes involved in MHC class I antigen presentation}

To determine which pathways in the $\mathrm{Cr} 2^{-/-}$cancer cells led to reduced tumor growth and increased cell death, we isolated cancer cells from $\mathrm{Crr}^{+/+}$and $\mathrm{Cr} 2^{-/-}$transplanted tumors formed 
A

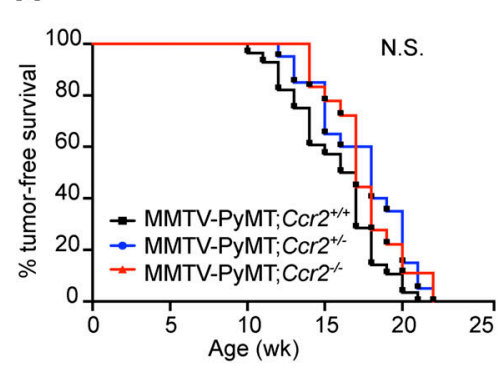

D MMTV-PyMT;CCr2 ${ }^{+/+}$

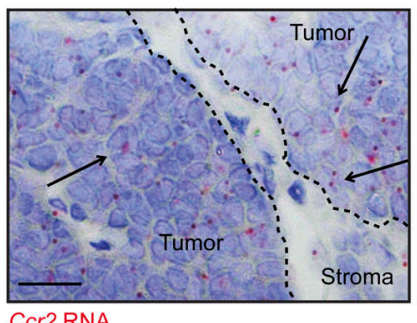

Ccr2 RNA
B

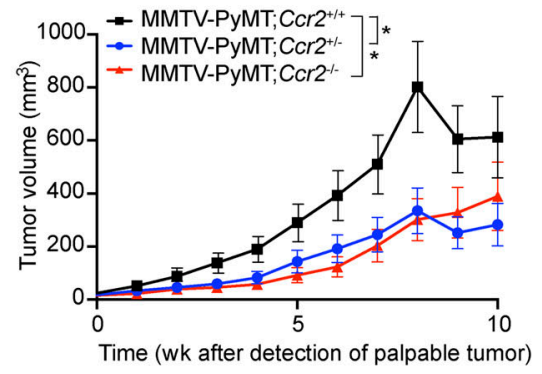

E

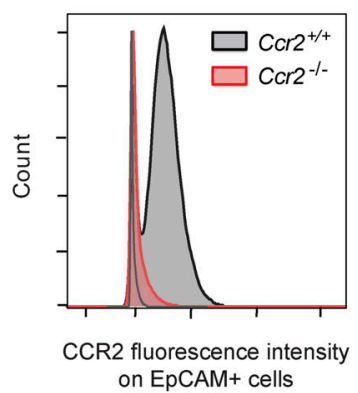

C
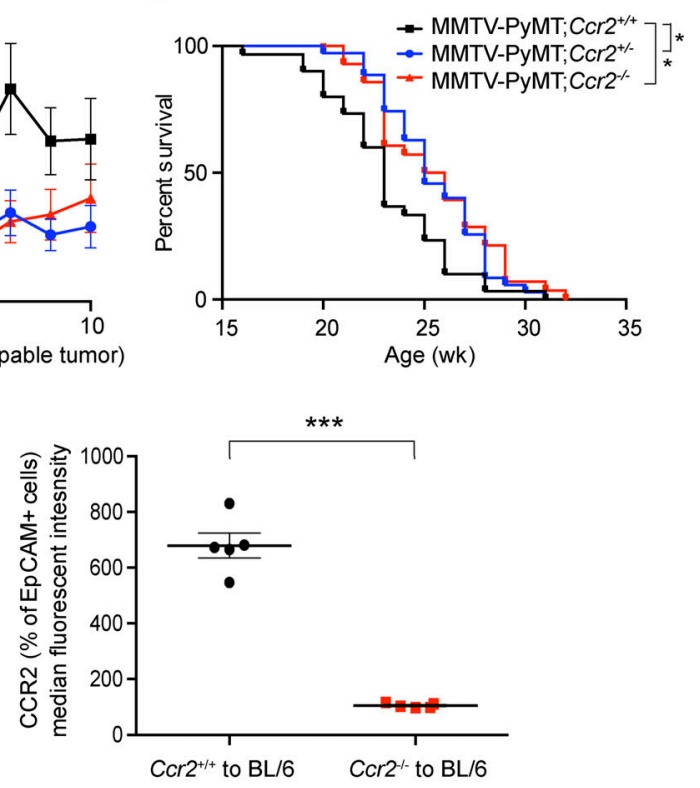

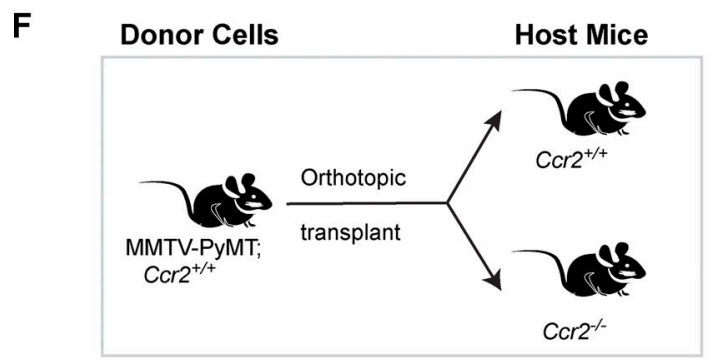

G

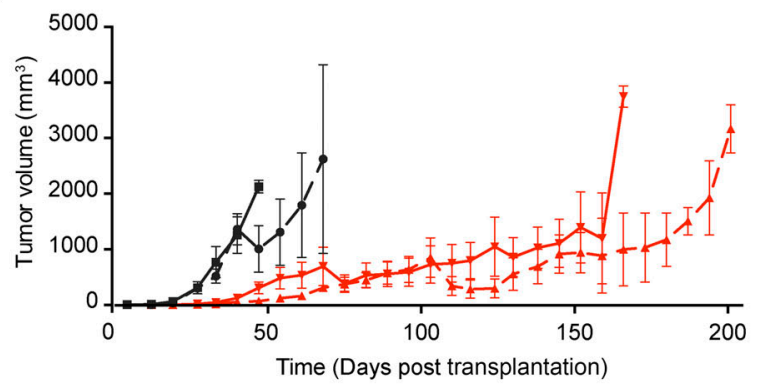

Host Mice

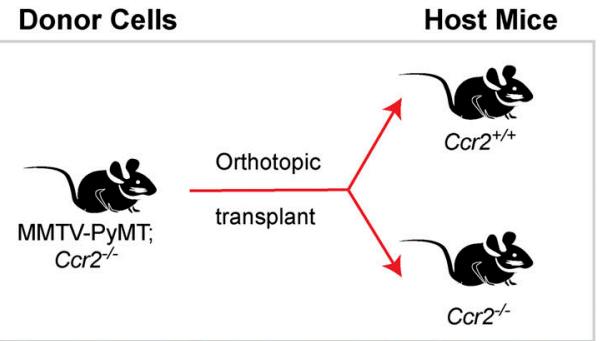

H

Figure 1. Cancer cell Ccr2 promotes primary tumor growth, reducing overall survival. (A) Tumor onset (tumor-free survival) is similar for MMTV-PyMT; $\mathrm{Ccr}^{+/+}, \mathrm{MMTV}-\mathrm{PyMT} ; \mathrm{Ccr2}^{+/-}$, and MMTV-PyMT; $\mathrm{Crr}^{-/-}$mice, as determined by weekly palpation and caliper measurement (log-rank [Mantel-Cox] test; $n=$ 28 MMTV-PyMT;CCr2+/+, 20 MMTV-PyMT;C Cr2 ${ }^{+/-}$, and 18 MMTV-PyMT;Ccr2 $2^{-/-}$mice). (B) Primary tumor growth is reduced in MMTV-PyMT;Ccr2 $2^{+/-}$and MMTV-PyMT; $\mathrm{CCr}^{-/-}$mice compared with MMTV-PyMT; $\mathrm{Cr}^{2+/+}$ mice, as determined by weekly caliper measurements (Welch's ANOVA followed by Dunnett's T3 multiple comparisons test was performed to compare tumor volume at the 8-wk time point [last time point before many MMTV-PyMT; $C \mathrm{Cr} 2^{+/+}$mice were euthanized due to large tumor burden]; $n=21$ MMTV-PyMT; $C \mathrm{Cr}^{+/+}, 25$ MMTV-PyMT;CCr2 ${ }^{+/-}$, and 18 MMTV-PyMT;C Cr2 $2^{-/-}$mice). (C) Time until IACUCapproved endpoint was increased for MMTV-PyMT;C Cr2 ${ }^{+/-}$and MMTV-PyMT;Ccr2-/- mice compared with MMTV-PyMT;Ccr2 ${ }^{+/+}$mice (log-rank [Mantel-Cox] test, Bonferroni corrected; $n=30$ MMTV-PyMT;CCr2 ${ }^{+/+}, 35$ MMTV-PyMT;C Cr2 ${ }^{+/-}$, and 29 MMTV-PyMT; Ccr2 $2^{-1-}$ mice). (D) Cancer cells express CCR2 (arrows) as determined by RNA ISH for Ccr2 performed on paraffin-embedded tumor sections from MMTV-PyMT; $C \mathrm{Cr} 2^{+/+}$mice. Image is representative of $>10$ mice. Scale bar $=20 \mu \mathrm{m}$. (E) CCR2 is expressed on epithelial cells, as determined by flow cytometry performed on Ccr2 $2^{+/+}$or Ccr2 ${ }^{-/-}$tumors transplanted to C57BL/6 hosts. Anti-CCR2 primary antibody was gated on EpCAM ${ }^{+}$cells and compared with background levels. Left panel shows one representative experiment, and right panel depicts median fluorescence intensity for all experiments (Student's $t$ test; $n=5$ ). (F) Schematic of transplantation experiments. (G) Primary tumor growth of $\mathrm{Ccr2}^{-/-}$cancer cells is reduced compared with that of $\mathrm{Ccr}^{+/+}$cancer cells regardless of the Ccr2 genotype of the host, as determined by weekly caliper measurements (one-way ANOVA was performed for the tumor volume analysis at day 33 [last time point with all $\mathrm{Ccr2}^{+/+}$hosts transplanted with $\mathrm{Ccr} 2^{+/+}$ cancer cells alive] and at day 40 [last time point with all $\mathrm{Ccr}^{-/-}$hosts transplanted with $\mathrm{Ccr}^{+/+}$cancer cells alive], followed by Sidak's multiple comparisons 
test; Student's $t$ test was performed for the tumor volume analysis at day 68 [last time point with all $\mathrm{Crr}^{-/-}$hosts transplanted with $\mathrm{Ccr} 2^{-/-}$cancer cells alive]; $n=8$ for all conditions). (H) Survival until IACUC-defined endpoint is increased in mice bearing $\mathrm{Ccr}^{-/-}$cancer cells regardless of the genotype of the host (log$\operatorname{rank}\left[\right.$ Mantel-Cox] test; $n=4$ for all conditions). Means $\pm S E M$ are indicated $(B, E$, and $G)$. $P$ values were determined by the tests indicated. ${ }^{*}, P<0.05 ;{ }^{* *}, P<$ $0.01 ;{ }^{* *}, \mathrm{P}<0.001$. N.S., nonsignificant.

in wild-type hosts for equal amounts of time and performed transcriptome profiling by RNA sequencing (RNA-seq). Overall, 520 genes were differentially expressed (adjusted $\mathrm{P}$ value $<0.05), \sim 40 \%$ of which were up-regulated in $\mathrm{Ccr2}^{-/-}$ cancer cells compared with $\mathrm{Crr} 2^{+/+}$cancer cells. Among the differentially expressed genes, we detected up-regulation of MHC class I (H2-K1) and Tap1, two genes required for antigen presentation, and IFI27, an IFN response gene, in the $\mathrm{Ccr2}^{-/-}$ cancer cells (Fig. 3 A). Vimentin, which is found in poorly differentiated epithelial cells and in mesenchymal cells, was down-regulated in $\mathrm{Ccr2}^{-/-}$cancer cells. This is consistent with a previous study describing a mesenchymal and invasive phenotype in CCR2-expressing cancer cells (Hu et al., 2019). Additionally, gene set enrichment analysis showed robust expression enrichment of the IFN- $\gamma$ response hallmark gene set, which included genes involved in antigen processing and presentation, in $\mathrm{Ccr}^{-/-}$cancer cells compared with $\mathrm{Ccr}^{+/+}$ cancer cells (Fig. 3 B). We also observed a pronounced luminal gene expression signature in the $\mathrm{Ccr}^{-/-}$cancer cells (Fig. $3 \mathrm{~B}$ ), in agreement with the noted histological differences (Fig. 2, A and $\mathrm{B}$ ). Consistently, gene ontology (GO) term analysis revealed altered expression of pathways involved in (1) regulation
A

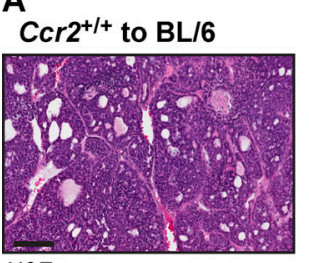

H\&E

C

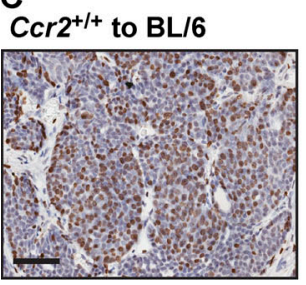

Ki67

$\mathrm{E}$

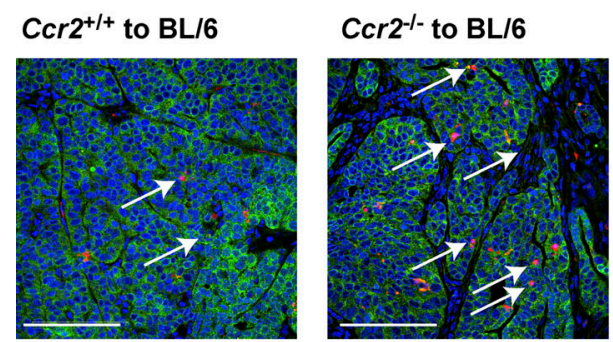

DAPI PYMT Cleaved caspase-3

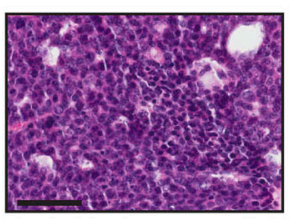

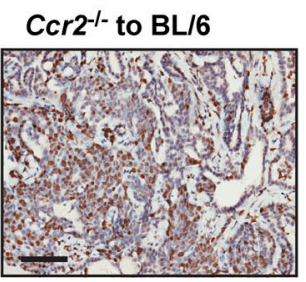
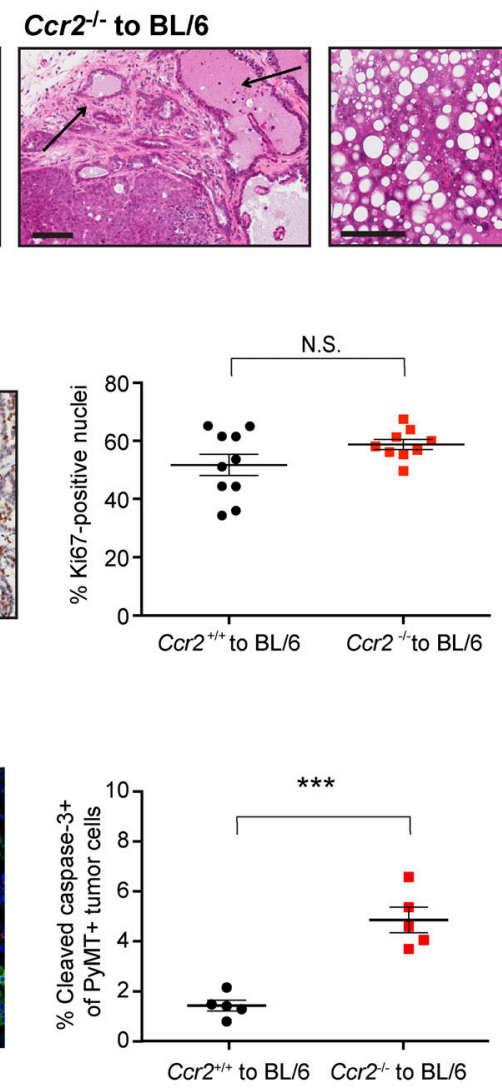

B
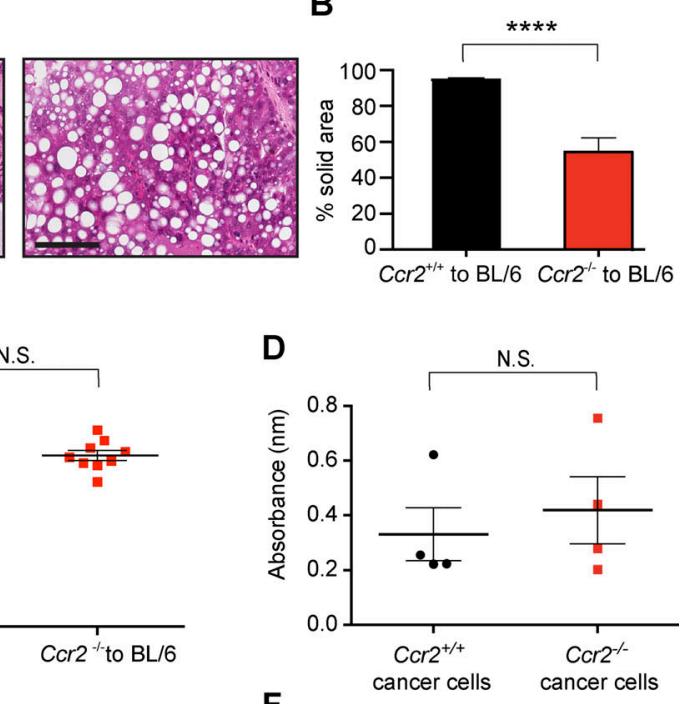

$\mathbf{F}$

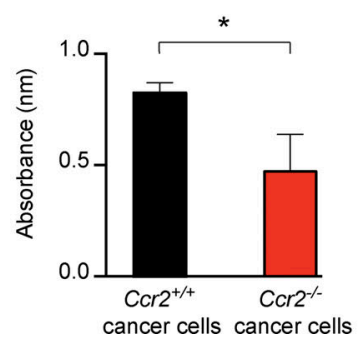

Figure 2. Loss of Ccr2 increases apoptosis in vivo with no effect on proliferation. (A) Four representative photomicrographs of H\&E-stained tumors derived from $\mathrm{Ccr}^{+/+}$and $\mathrm{Ccr}^{-/-}$cancer cells. Arrows denote cystic areas. Also note lipid vacuoles in tumors from $\mathrm{Ccr} 2^{-/-}$cancer cells. Scale bar $=100 \mu \mathrm{m}$. (B) Histology score of solid area in tumors from $\mathrm{Ccr}^{+/+}$and $\mathrm{Crr}^{-/-}$transplants $\left(n=10 \mathrm{in} \mathrm{Cr}^{+/+}\right.$, and $n=8$ in $\left.\mathrm{Ccr}^{-/-}\right)$. (C) Proliferation is unchanged between $\mathrm{CCr}^{+/+}$and $\mathrm{CCr}^{-/-}$tumor transplants during the growth-restricted phase, as determined by Ki67-positive nuclear stain. Left panels are representative photomicrographs (scale bar $=100 \mu \mathrm{m})$, and right panel shows quantification $\left(n=10\right.$ and 9 for $\mathrm{Ccr}^{+/+}$and $\mathrm{Ccr} 2^{-/-}$transplants, respectively). (D) Proliferation is unchanged in $\mathrm{Ccr}^{+/+}$and $\mathrm{Ccr}^{-/-}$cancer cells in vitro during the growth-restricted phase, as determined by absorbance after $24 \mathrm{~h}$ using CellTiter $96 \mathrm{AQueous}$ One Solution Cell Proliferation (MTS) Assay $(n=4)$. (E) $\mathrm{Ccr2}^{-/-}$cancer cells have an increased apoptotic index compared with $\mathrm{Ccr} 2^{-/-}$cancer cells during the growth-restricted phase, as determined by double immune staining for PyMT and cleaved caspase-3. Left panels are representative photomicrographs, with arrows indicating apoptotic cancer cells (scale bar $=100 \mu \mathrm{m})$; right panel shows quantification $(n=5)$. Each dot represents an average of five random fields of views from one tumor. (F) $\mathrm{Crr}^{-/-}$cancer cells are less viable than $\mathrm{Crr}^{+/+}$cancer cells in serum-free conditions, as determined by absorbance in MTS assay after serum starvation for $24 \mathrm{~h}(n=3)$. Means \pm SEM are indicated. P values were determined by Student's $t$ test. ${ }^{*}, \mathrm{P}<0.05 ;{ }^{* * *}, \mathrm{P}<0.001 ;{ }^{* * * *}, \mathrm{P}<0.0001$. N.S., nonsignificant. 
A

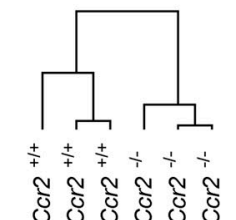

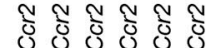
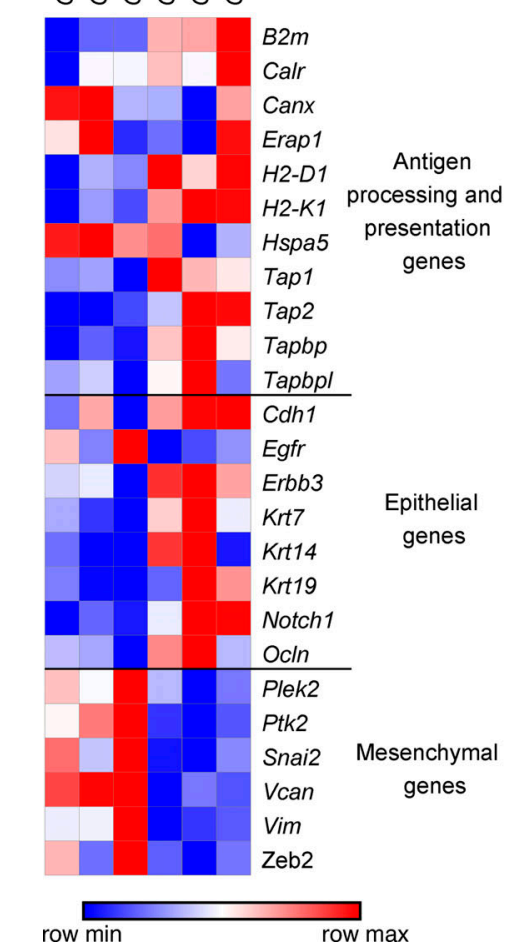

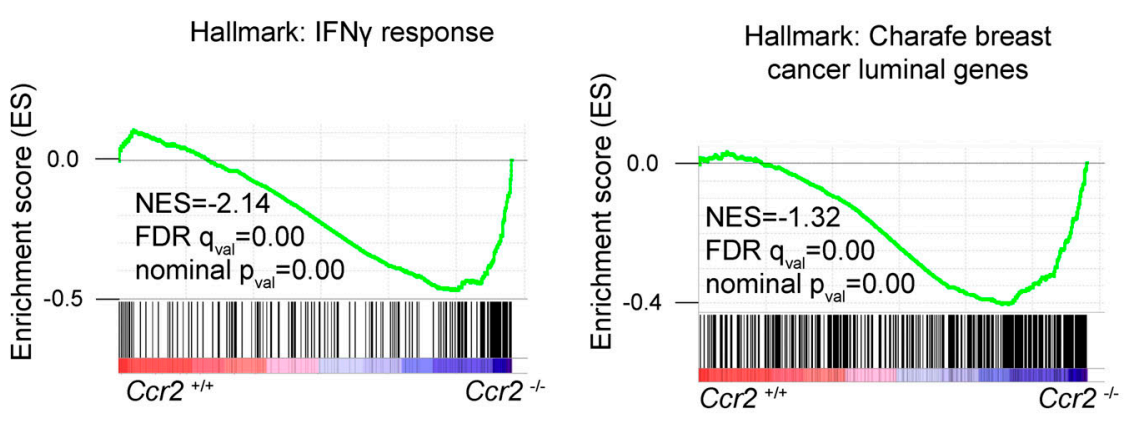

Figure 3. Ccr2 $2^{-/-}$cancer cells have increased expression of IFN response genes and of genes involved in MHC class I antigen presentation. (A) A hierarchically clustered heat map of $\mathrm{CCr}^{+/+}$and $\mathrm{CCr}^{-/-}$cancer cell samples collected during the growth-restricted phase, based on expression levels of select genes associated with antigen processing and presentation, as well as epithelial-to-mesenchymal transition ( $n=3$ for $\mathrm{Ccr}^{+/+}$and $\mathrm{Ccr} 2^{-/-}$tumors). (B) Gene set enrichment analysis plots showing enrichment of IFN-y response and luminal gene set expression in $\mathrm{Ccr}^{-/-}$cancer cells. NES, normalized enrichment score. (c) GO term enrichment plots showing the most significantly overrepresented GO terms in $\mathrm{Crr}^{-/-}$cancer cells compared with $\mathrm{Ccr} 2^{+/+}$cancer cells. Statistical analyses for RNA-seq data are described in the Materials and methods section. FDR, false discovery rate; max, maximum; min, minimum; proc., processing; pres., presentation.

of the adaptive immune system and in (2) response to immunemediated cell killing (Fig. $3 \mathrm{C}$ ).

\section{Cancer cell CCR2 promotes immune suppression}

The increased expression of genes associated with IFN response and antigen presentation, together with the prolonged growth delay and increased apoptosis in tumors from $\mathrm{Ccr}^{-/-}$cancer cells, is consistent with an ongoing adaptive immune response in the tumors. We therefore determined whether there were any differences in the infiltrating immune cell populations by flow cytometry (for gating strategy, see Fig. S2). There were significantly more $\mathrm{CD} 8^{+}$CTLs and fewer $\mathrm{CD} 4^{+}$helper $\mathrm{T}$ cells in tumors from $\mathrm{Ccr2}^{-/-}$cancer cells than in tumors from $\mathrm{Ccr2}^{+/+}$cancer cells (Fig. $4 \mathrm{~A}$ ), with no overall change in $\mathrm{CD}^{+} \mathrm{T}$ cell infiltration (Fig. S3 A). Increased infiltration of $\mathrm{CD}^{+}$cells into tumors derived from $\mathrm{Ccr2}^{-/-}$cancer cells was also evident by immunofluorescence (Fig. 4, B and C). PD-1 is an inhibitory checkpoint surface molecule expressed by activated $\mathrm{CD} 8^{+} \mathrm{T}$ cells (Chen et al., 2016a), and its expression was increased on $\mathrm{CD} 8^{+} \mathrm{T}$ cells from tumors from $\mathrm{Ccr}^{-/-}$cancer cells (Fig. $\left.4 \mathrm{D}\right)$. CTLs kill, in part, through the release of granzyme B, a process that requires lysosomalassociated membrane protein 1 (LAMP-1; also known as Cluster of Differentiation 107a [CD107a]). In tumors from $\mathrm{Ccr}^{-/-}$ cancer cells, LAMP-1 was increased on the cell surface of $\mathrm{CD} 8^{+}$ $\mathrm{T}$ cells (Fig. $4 \mathrm{E}$ ), while granzyme $\mathrm{B}$ levels were reduced in $\mathrm{CD} 8^{+}$ $\mathrm{T}$ cells (Fig. $4 \mathrm{~F}$ ), indicating increased levels of prior $\mathrm{CD}^{+}$degranulation and therefore cytotoxic activity. Regulatory $\mathrm{T}$ lymphocytes $\left(\mathrm{CD}^{+}{ }^{+} \mathrm{FoxP}^{+}\right.$regulatory $\mathrm{T}$ cells), which are typically immunosuppressive, were more abundant in tumors from $\mathrm{CCr}^{-{ }^{-}-}$ cancer cells (Fig. S3 B).

Tumors from $\mathrm{Ccr2}^{-/-}$cancer cells had multiple changes in the adaptive immune cell infiltrate, all consistent with an active immune response. Therefore, we tested whether an adaptive immune response contributed to the differences in growth rates between the $\mathrm{Ccr2}^{+/+}$and $\mathrm{Ccr}^{-/-}$tumors by transplanting cancer cells in parallel into $\mathrm{T}$ cell-deficient athymic (nude) or fully immunocompetent mice (Fig. $5 \mathrm{~A}$ ). In the immunocompetent hosts, tumors from $\mathrm{CCr}^{-/-}$cancer cells 
A $\mathrm{Ccr2}^{+/+}$to BL/6

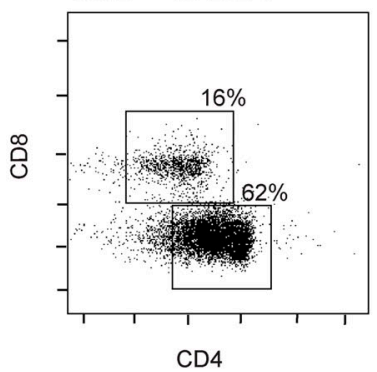

Ccr2--/- to BL/6

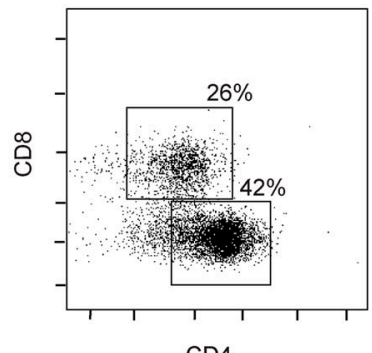

CD4
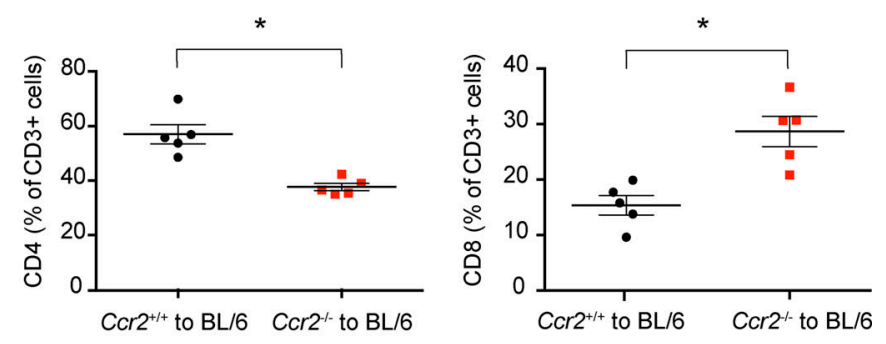

B $\mathrm{Ccr2}^{+/+}$to $\mathrm{BL} / 6$

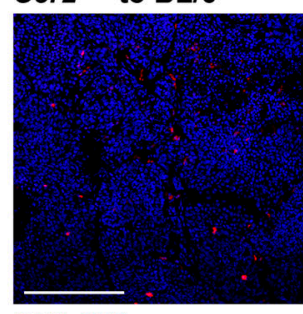

DAPI CD8a

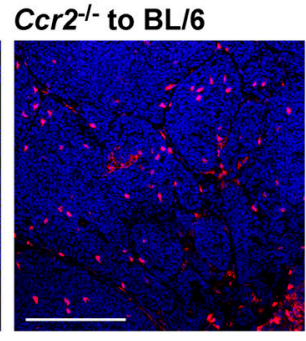

C

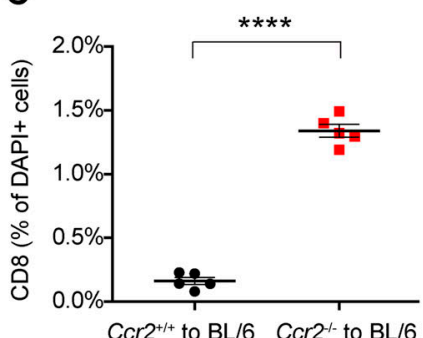

D

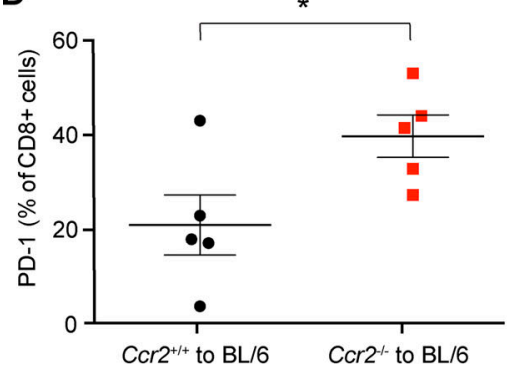

E

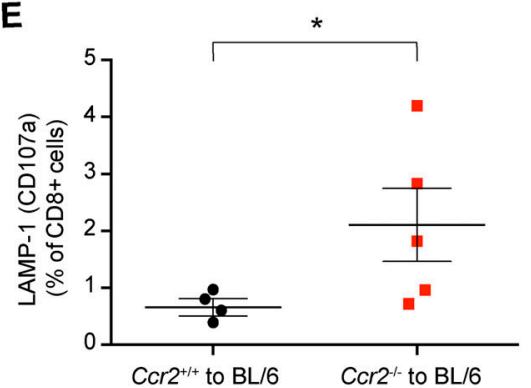

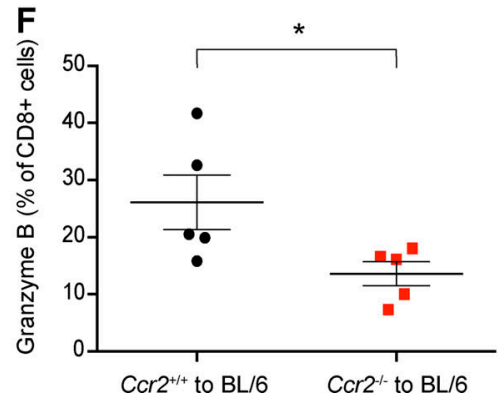

Figure 4. Tumors derived from Ccr2 ${ }^{-/-}$cancer cells have increased infiltration of activated CTLs. (A) Tumors from $\mathrm{Ccr}^{-/-}$cancer cells have fewer CD4 ${ }^{+}$ $\mathrm{T}$ cells and more $\mathrm{CD} 8^{+} \mathrm{T}$ cells during the growth-restricted phase, as determined by flow cytometry gated on $\mathrm{CD} 45^{+} \mathrm{CD} 3^{+}$cells. Left panels are representative examples of dot plots, and right panels show quantification of $C D 4^{+}$and $C D 8^{+}$cells $(n=5)$. (B) Representative immunofluorescence staining showing that more $\mathrm{CD} 8 \mathrm{a}^{+} \mathrm{T}$ cells (red) infiltrate into tumors derived from $\mathrm{Ccr}^{-/-}$cancer cells than tumors from $\mathrm{Ccr}{ }^{+/+}$cancer cells during the growth-restricted phase $(\mathrm{scale}$ bar $=$ $100 \mu \mathrm{m}$ ). (C) Quantification of CD8a+ T cells in the tumors ( $n=5$ tumors; each dot represents the average of five random fields of views of one tumor). (D) PD- 1 levels were increased in $\mathrm{CD} 8^{+} \mathrm{T}$ cells in tumors from $\mathrm{Ccr}^{-/-}$cancer cells during the growth-restricted phase, as determined by flow cytometry gating on $\mathrm{CD}^{2} 5^{+} \mathrm{CD} 3^{+} \mathrm{CD} 8^{+}$ cells $(n=5)$. (E) LAMP-1 (CD107a) levels were increased in CD8 ${ }^{+} \mathrm{T}$ cells in $\mathrm{Cr} 2^{-/-}$tumors during the growth-restricted phase, as determined by flow cytometry gated on $\mathrm{CD}_{4} 5^{+} \mathrm{CD}^{+} \mathrm{CD}^{+}$cells $\left(n=4\right.$ and 5 for $\mathrm{Ccr} 2^{+/+}$and $\mathrm{Crr}^{-/-}$transplants, respectively). (F) Intracellular granzyme B levels were decreased in $\mathrm{CD} 8^{+} \mathrm{T}$ cells in $\mathrm{Ccr} 2^{-/-}$tumors during the growth-restricted phase, as determined by flow cytometry gated on $C D 45^{+} C D 3^{+} C D 8^{+}$cells, after $2 \mathrm{~h}$ of incubation with Brefeldin $\mathrm{A}(n=5)$. Means $\pm \mathrm{SEM}$ are indicated. P values were determined by Student's $t$ test. ${ }^{*}, \mathrm{P}<0.05$ (A and D-F); ${ }^{* * *}, \mathrm{P}<0.0001$ (C).

grew significantly more slowly than tumors from $\mathrm{Ccr}^{+/+}$ cancer cells (Fig. 5 B), as previously observed (Fig. $1 \mathrm{G}$ ). In contrast, in the $\mathrm{T}$ cell-deficient hosts, the $\mathrm{Ccr}^{-/-}$tumors grew at a similar rate as the $\mathrm{Crr} 2^{+/+}$tumors (Fig. 5 C). Consistently, tumors derived from $\mathrm{Ccr}^{-/-}$cancer cells grew as fast as tumors derived from $\mathrm{Crr} 2^{+/+}$cancer cells when $\mathrm{CD} 8^{+} \mathrm{T}$ cells were depleted from wild-type mice (Fig. S3 C). Furthermore, in the $\mathrm{T}$ cell-deficient, athymic hosts, tumors from $\mathrm{Ccr2}^{-/-}$cancer cells no longer had more apoptotic cells than tumors from $\mathrm{Ccr}^{+/+}$cancer cells (Fig. $5 \mathrm{D}$ ). Interestingly, the differentiated histological phenotype of the tumors from the $\mathrm{C}_{\mathrm{C} 2}{ }^{-/-}$cancer cells was maintained in the athymic mice (Fig. 5, E and F). Thus, the histological differences were not the result of an altered adaptive immune response. Together, these data demonstrate that CCR2 expressed by cancer cells enables the tumors to escape the adaptive immune response.
We next speculated that the reduced growth of tumors from $\mathrm{Ccr} 2^{-/-}$cancer cells could be a result of increased sensitivity to CTL-induced cell death, given that the $\mathrm{Ccr2}^{-/-}$cancer cells showed increased sensitivity to serum-free conditions and that the tumors grew normally when $\mathrm{CD} 8^{+} \mathrm{T}$ cells were depleted. To test this possibility, we used the MMTV-PyMT-mCherryOVA (chOVA) model (Engelhardt et al., 2012), which is driven by the PyMT oncogene and coexpresses OVA as a model tumor antigen and mCherry for tracking. We generated MMTVPyMT-chOVA;CCr2 ${ }^{+/+}$and MMTV-PyMT-chOVA;Crr2 $2^{-/-}$mice and found that similar to the MMTV-PyMT; $\mathrm{Crr}^{-/-}$tumors, the MMTV-PyMT-chOVA;Ccr2 ${ }^{-1-}$ tumors grew more slowly than MMTV-PyMT-chOVA;Crr2 $2^{+/+}$tumors (Fig. 6 A). When primary cancer cells were isolated and challenged with activated CTLs isolated from OT-1 mice (where $\mathrm{T}$ cells are engineered to recognize an OVA peptide presented by MHC class 
Host Mice
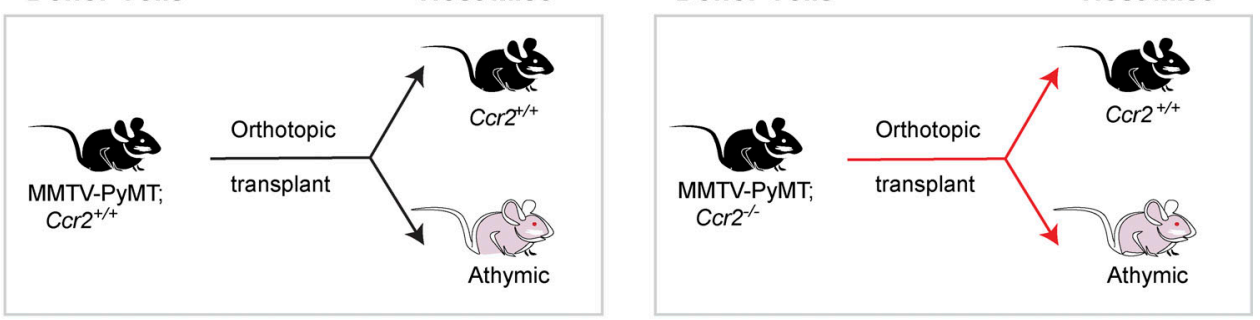

B

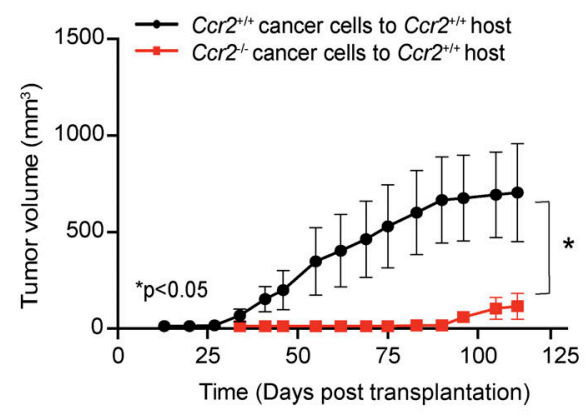

C

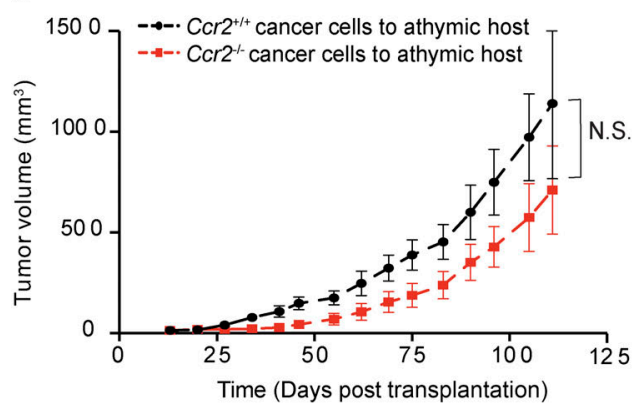

D
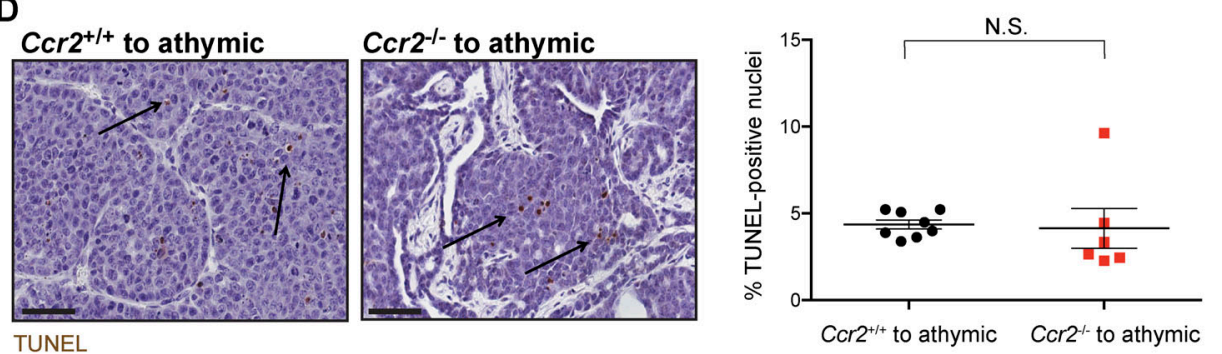

E

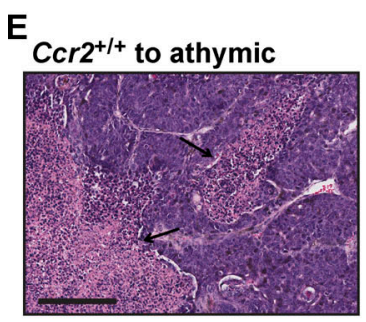

H\&E

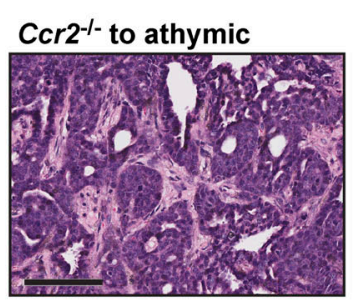

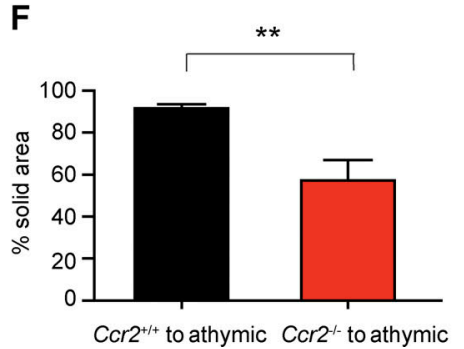

Figure 5. Cancer cell Ccr2 tumor growth requires functional adaptive immunity. (A) Schematic of experimental design. (B) Tumors from Ccr2 ${ }^{+/+}$cancer cells grow faster than tumors from $\mathrm{Crr}^{-/-}$cancer cells in mice with intact immune systems. Tumor burden was determined by weekly caliper measurements. Mice were sacrificed at IACUC-approved endpoint ( $n=20$ per condition). (C) Tumors from Ccr2 ${ }^{+/+}$cancer cells grow similarly to tumors from Ccr2 ${ }^{-/-}$cancer cells in athymic host mice. Tumor burden was determined by weekly caliper measurement. Mice were sacrificed at IACUC-approved endpoint $(n=20$ per condition). (D) Apoptosis was unchanged between $\mathrm{C} C 2^{+/+}$and $\mathrm{Ccr}^{-/-}$transplants to athymic hosts, as determined by TUNEL stain. Left panels are representative photomicrographs (scale bar $=100 \mu \mathrm{m})$, with arrows pointing to apoptotic cells; right panel shows quantification $\left(n=8\right.$ and $6 \mathrm{for} C \mathrm{cr} 2^{+/+}$and $\mathrm{Ccr} 2^{-/-}$ transplants, respectively). (E) Representative H\&E staining of transplanted tumors from $\mathrm{Ccr2} 2^{+/+}$and $\mathrm{Ccr2}^{-/-}$cancer cells to nude hosts. Arrows indicate highly necrotic areas (scale bar $=100 \mu \mathrm{m})$. (F) Histology score of solid area of transplanted tumors from $\mathrm{Ccr2}^{+/+}$and $\mathrm{Ccr}^{-/-}$cancer cells to athymic hosts $(n=10$ in $\mathrm{Crr}^{+/+}$and $n=9$ in $\left(\mathrm{cr}^{-/-}\right)$. Means \pm SEM are indicated. P values were determined by $t$ test with Welch's correction (B) or by Student's $t$ test (C) for tumor volume analysis at the end time point and by Student's $t$ test $(\mathrm{D}$ and $\mathrm{F}){ }^{*}, \mathrm{P}<0.05{ }^{* *}, \mathrm{P}<0.01$. N.S., nonsignificant.

I), we found that MMTV-PyMT-chOVA;Ccr2-/- cancer cells were approximately twice as sensitive to CTLs as MMTVPyMT-chOVA;Crr2 ${ }^{+/+}$cancer cells (Fig. 6 B). Upon treatment with a pharmacological inhibitor against CCR2 (RS 102895 hydrochloride; Mitchell et al., 2013), the MMTV-PyMT-chOVA; $\mathrm{Ccr2}^{+/+}$cancer cells became as sensitive to the OVA-specific CTLs as the MMTV-PyMT-chOVA;Ccr2 $2^{-/-}$cancer cells (Fig. 6 C). The CCR2 inhibitor also increased specific cytolysis of the
OVA-expressing E0771 murine breast cancer cell line to the OVA-specific CTLs (Fig. S3 D). In contrast, the CCR2 inhibitor had no effect on the specific cytotoxicity of the CTLs to the MMTV-PyMT-chOVA;Ccr2 ${ }^{-/-}$cancer cells (Fig. 6 C).

To test if Ccr2 expression in cancer cells also regulated sensitivity to CTLs in vivo, we measured the clonal expansion of $\mathrm{T}$ cells, an indicator of active proliferation of antigen-specific $\mathrm{T}$ cells, by sequencing the complementarity determining 

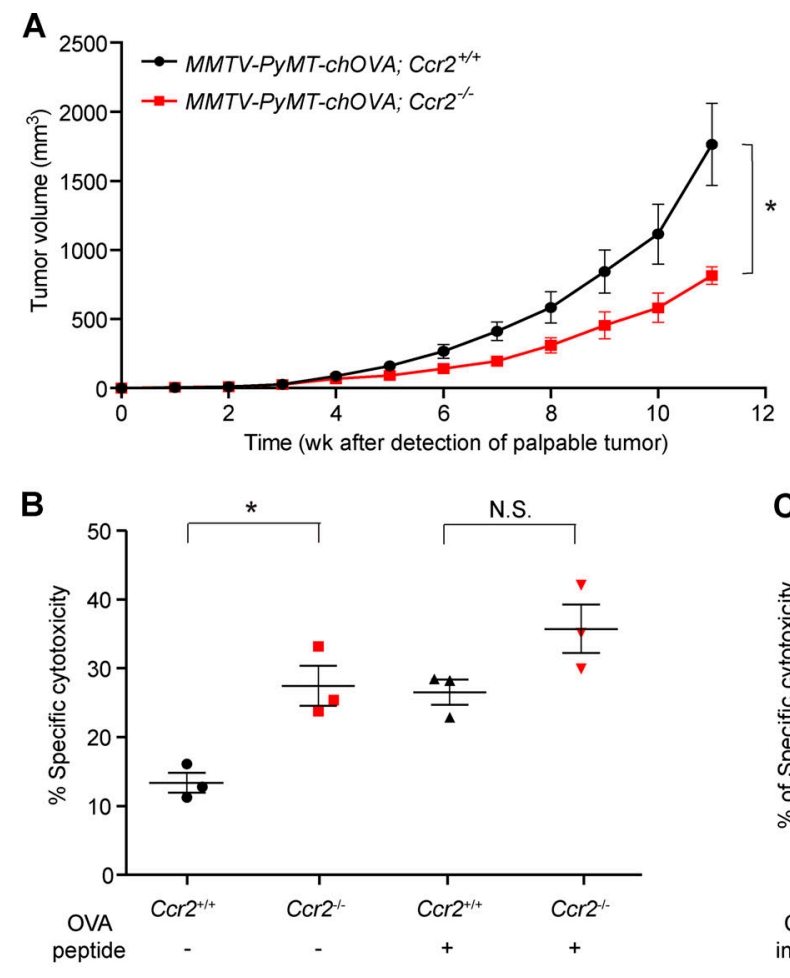

D
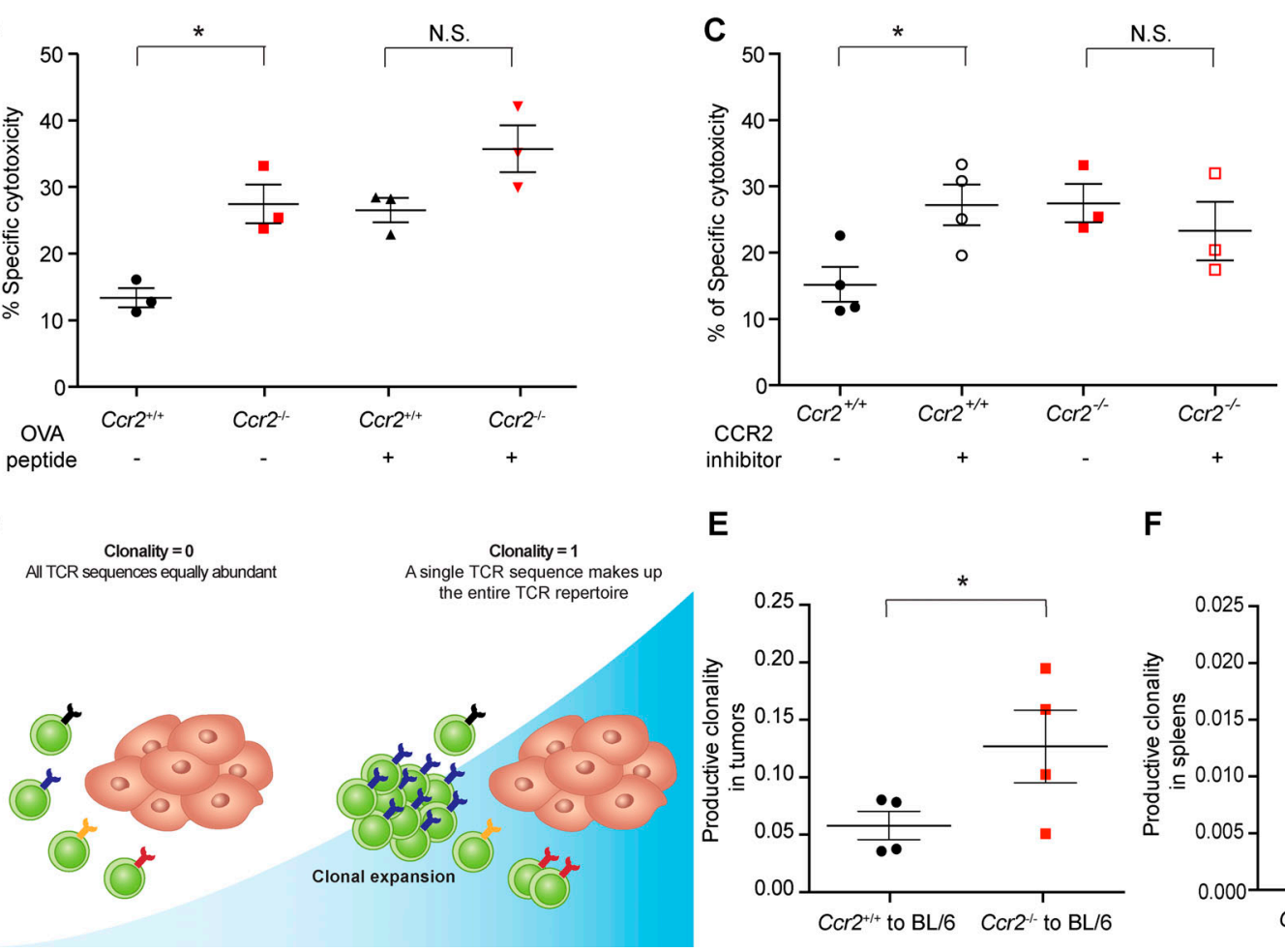

E

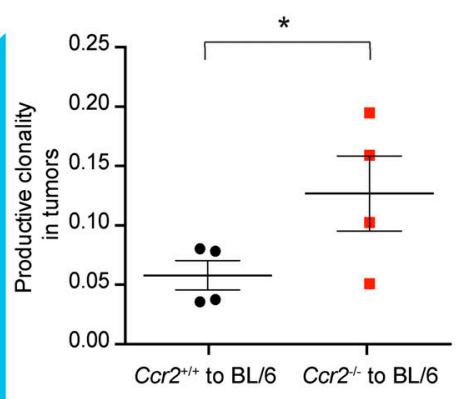

$\mathbf{F}$

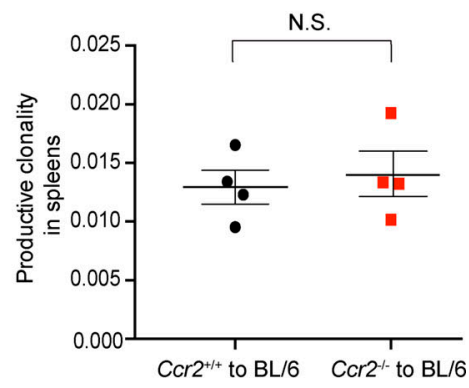

Figure 6. Cancer cell Ccr2 signaling protects against T cell-mediated killing. (A) Primary tumor growth is reduced in MMTV-PyMT-chOVA;C Cr2 ${ }^{-/-}$mice compared with MMTV-PyMT-chOVA;C $\mathrm{Cr} 2^{+/+}$mice, as determined by weekly caliper measurements once the tumors were palpable $\left(n=6 \mathrm{MMTV}\right.$-PyMT; $C \mathrm{cr} 2^{+/+}$

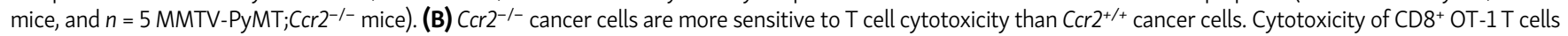
toward MMTV-PyMT-chOVA;Ccr2 ${ }^{+/+}$or MMTV-PyMT-chOVA;Ccr2 ${ }^{-/-}$primary cancer cells, with or without OVA peptides, measured by chromium $\left(\mathrm{Cr}^{51}\right)$ release $(n=3)$. (C) Inhibiting CCR2 increased T cell cytotoxicity against $\mathrm{Ccr2}^{+/+}$cancer cells. Cytotoxicity of CD8 $8^{+}$OT-1 T cells toward MMTV-PyMT-chOVA;Ccr2 ${ }^{+/+}$or MMTV-PyMT-chOVA; $C \mathrm{Cr}^{-/-}$cancer cells, with or without CCR2 inhibitor, measured by chromium $\left(\mathrm{Cr}^{51}\right)$ release (each dot is the average of triplicate from an independent experiment; $n=4$ and 3 for MMTV-PyMT-chOVA;Ccr2 $2^{+/}$and MMTV-PyMT-chOVA;Ccr2-/- cancer cells, respectively). (D) Model of clonality measured by TCR sequencing. (E) Productive clonality in tumors from $\mathrm{CCr}^{+/+}$and $\mathrm{Ccr2}^{-/-}$cancer cells $(n=4)$. (F) Productive clonality in spleens was unchanged between $\mathrm{Ccr}^{+/+}$and $\mathrm{Cr}^{-/-}$tumors $(n=4)$. Statistical analysis of TCR sequencing data is described in the Materials and methods section. Means \pm SEM are indicated. P values were determined for tumor volume analysis at the end time point using $t$ test with Welch's correction (A) or Student's $t$ test (B, C, E, and F). *, $P<0.05$. N.S., nonsignificant.

region 3 (CDR3) region of the $\mathrm{T}$ cell receptor (TCR) $\beta$ chain. We found that clonality, a value corresponding to the extent of clonal expansion of $\mathrm{T}$ cells (Fig. $6 \mathrm{D}$ ), was significantly higher in tumors from $\mathrm{Ccr2}^{-/-}$cancer cells than in tumors from $\mathrm{Crr}^{+/+}$ cancer cells (Fig. $6 \mathrm{E}$ ), while there was no difference in clonality in the spleens of these groups of mice (Fig. 6 F). These results suggested that tumor-recognizing CTLs were actively expanding due to antigen recognition in tumors from $\mathrm{Ccr}^{-/-}$cancer cells, but that this expansion did not alter the systemic $\mathrm{T}$ cell response. Both $\mathrm{Ccr}^{+/+}$and $\mathrm{Ccr}^{-/-}$cancer cells express the PyMT tumor antigen, and $\mathrm{Crr} 2^{+/+}$cancer cells formed tumors at the same rate regardless of whether $\mathrm{CCr}^{+/+}$or $\mathrm{CCr}^{-/-}$cancer cells were transplanted to the contralateral mammary gland (Fig. S3 E). Together, these results suggest that the expression of CCR2 by cancer cells enables the tumors to establish a locally immune-suppressive microenvironment.

\section{Cancer cell CCR2 alters MHC class I and PD-L1 expression}

CCR2 signaling can activate STAT transcription factors in cancer cells (Chen et al., 2015; Izumi et al., 2013), and altered 
A
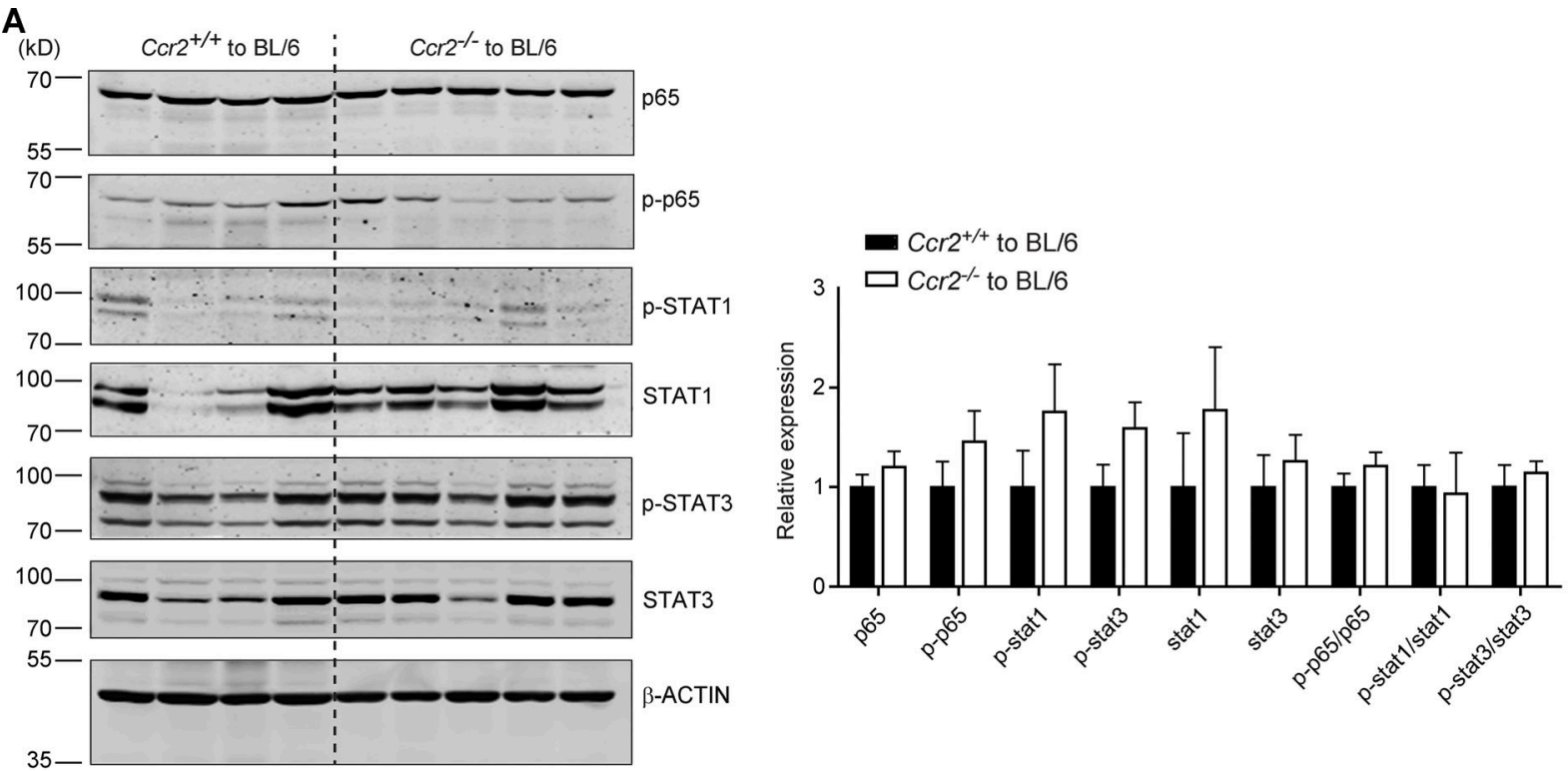

B
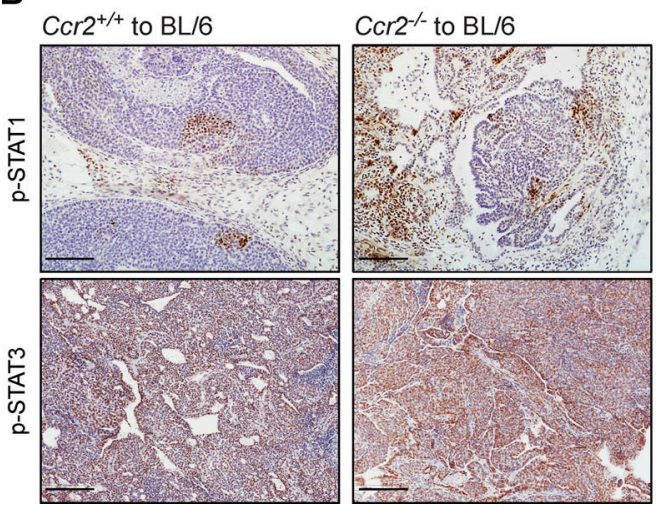

C
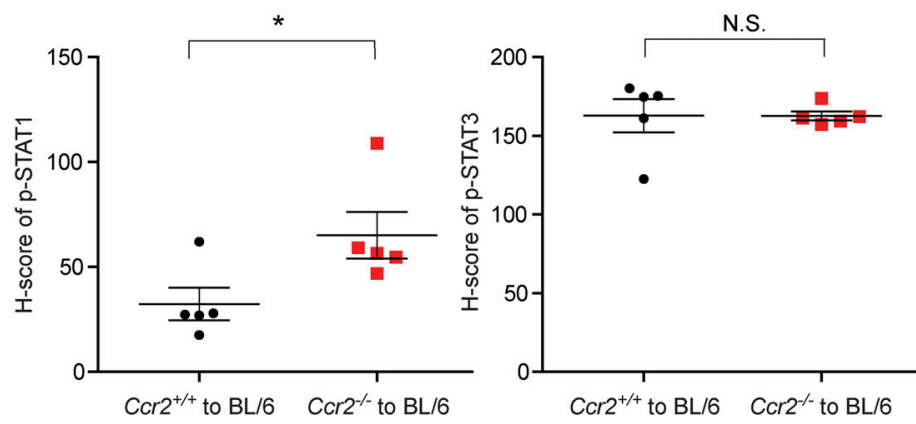

Figure 7. Localized STAT1 activation in Ccr2 ${ }^{-/-}$tumors. (A) Left: Comparison of STAT1 activation in tumors from $\mathrm{Ccr}^{+/+}$or $\mathrm{Ccr} 2^{-/-}$cancer cells during the growth-restricted phase by Western blot analysis. Each lane contains a protein sample from a tumor from a different mouse. Proteins with similar molecular weight were detected using blots from separate gels, loaded with equal amounts of samples. Right: Quantifications of protein expression normalized to $\beta$-actin levels $\left(n=4\right.$ for $\mathrm{Cr}_{2}{ }^{+/+}$, and $n=5$ for $\mathrm{Ccr}^{-/-}$). (B) Representative photomicrographs of p-STAT1 (top) and $\mathrm{p}$-STAT3 (bottom) staining in sections of tumors from $\mathrm{Ccr}^{+/+}$or $\mathrm{Ccr}^{-/-}$cancer cells. Scale bar $=100 \mu \mathrm{m}$. (C) Quantification of the immunohistochemical staining in B using H-score shows higher STAT1 phosphorylation in tumors from $\mathrm{Ccr2}^{-/-}$than in those from $\mathrm{Crr}^{+/+}$cancer cells but similar levels of STAT3 phosphorylation $(n=5)$. Means \pm SEM are indicated. $P$ values were determined by Student's $t$ test. ${ }^{*}, \mathrm{P}<0.05$. N.S., nonsignificant.

STAT1 or STAT3 signaling in cancer cells can in turn lead to a less immune-suppressive microenvironment (Ahn et al., 2017; Jones et al., 2016). Therefore, we tested whether STAT activation was different between tumors from $\mathrm{Crr} 2^{+/+}$ and $\mathrm{Ccr}^{-/-}$cancer cells. We found no consistent differences between the activation of STAT1, STAT3, or P65/RELA when whole tumor lysate was assayed by Western blot (Fig. 7 A). By immunohistochemistry, we found that the tumors contained patches of cancer cells with high expression of phosphoSTAT1, with more of these patches in the tumors from $\mathrm{Ccr2}^{-/-}$than from $\mathrm{Ccr}^{+/+}$cancer cells (Fig. 7, B and C). No difference was observed for phospho-STAT3. This suggested a localized, enhanced anti-tumor immune response regulated via STAT1 in tumors from $\mathrm{Ccr}^{-/-}$cancer cells compared with those from $\mathrm{Ccr2}^{+/+}$cells, consistent with other reports (Avalle et al., 2012).
We next sought to understand how CCR2 signaling in cancer cells resulted in more efficient immune suppression. RNA-seq analysis of the cancer cells showed increased expression of genes involved in antigen presentation in the $\mathrm{CCr}^{-1-}$ tumors (Fig. $3 \mathrm{~A}$ ). Consistently, we found high levels of MHC class I expressed by cancer cells in MMTV-PyMTchOVA; $\mathrm{Crr}^{-/-}$mice compared with the variable, low to intermediate levels expressed by cancer cells in MMTVPyMT-chOVA;C $C r 2^{+/+}$mice (Fig. 8 A). Similarly, when cancer cells were transplanted to immunocompetent host mice, expression of MHC class I was higher by $\mathrm{Crr}^{-/-}$cancer cells than by $\mathrm{Ccr}^{+/+}$cancer cells, as shown by immunofluorescence (Fig. 8 B). However, in T cell-deficient, athymic host mice, MHC class I levels were similar on $\mathrm{Ccr}^{+/+}$and $\mathrm{Ccr}^{-/-}$ cancer cells (Fig. $8 \mathrm{C}$ ). These data suggest that MHC class I expression is not directly regulated by CCR2 signaling in the 
A

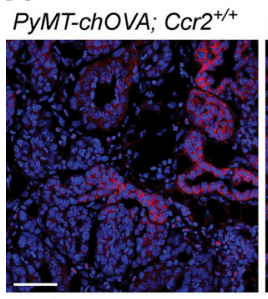

MHC class I DAPI

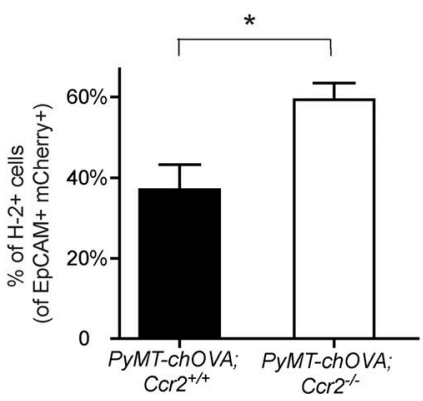

B

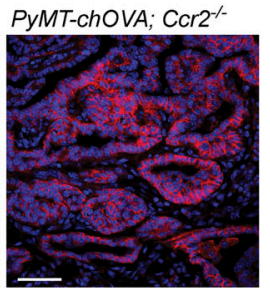

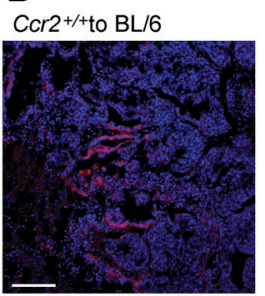

MHC class I DAPI

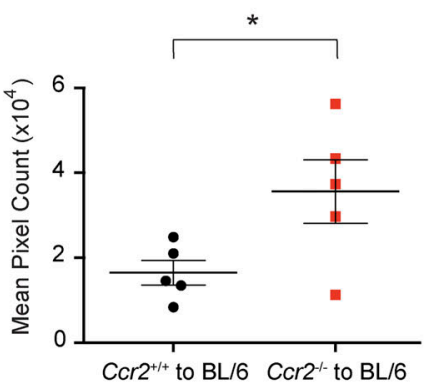

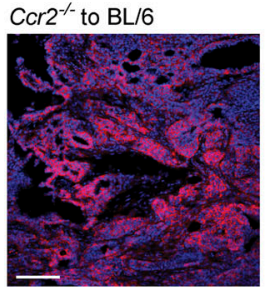

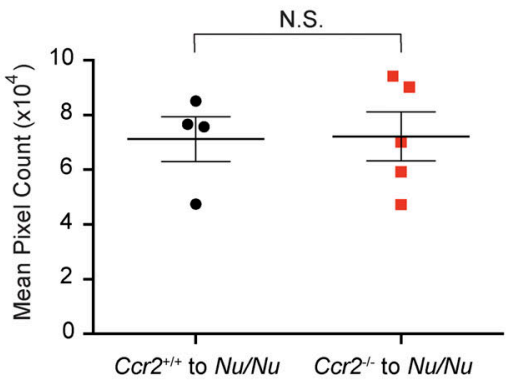

C

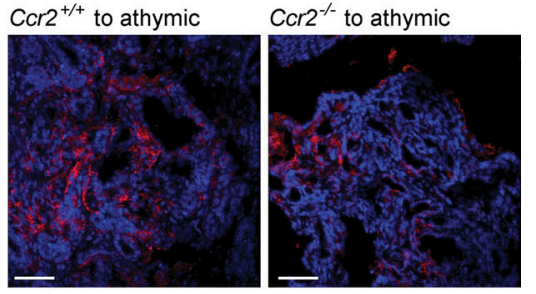

MHC class I DAPI

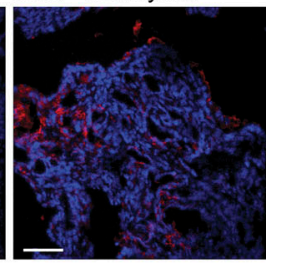

\section{列}

D

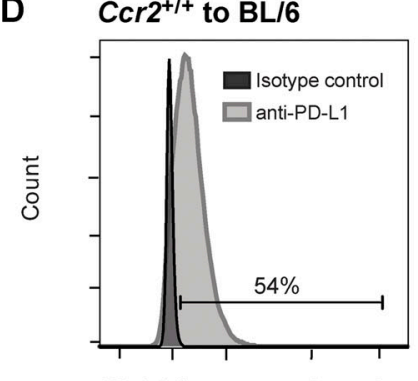

PD-L1 fluorescence intensity

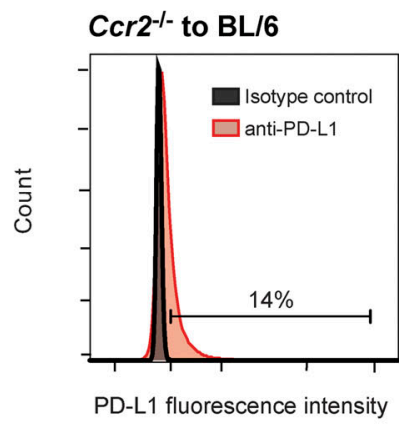

F
E

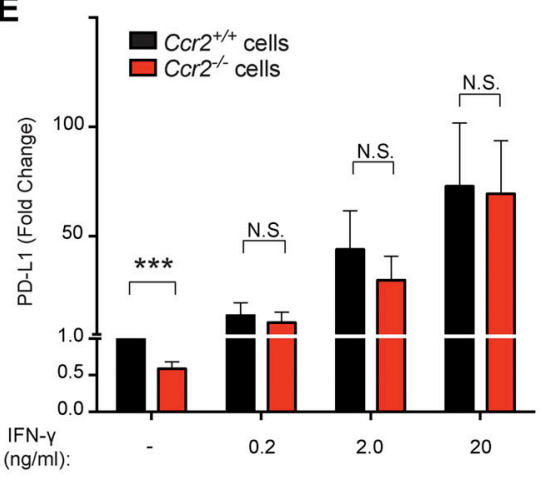

\section{.}

Figure 8. MHC class I expression is reduced and PD-L1 expression increased in Ccr2 ${ }^{+/+}$cancer cells in immunocompetent mice. (A) MHC class I expression is increased in MMTV-PyMT-chOVA; $\mathrm{Crr}^{-/-}$tumors compared with MMTV-PyMT-chOVA; $\mathrm{Ccr} 2^{+/+}$tumors during the growth-restricted phase, as determined by immunofluorescence staining (upper panels: representative images; scale bar $=50 \mu \mathrm{m}$ ) and by flow cytometry (bottom panel), gated on $\mathrm{EpCAM}^{+}, \mathrm{mCherry}^{+}$cells $\left(n=8\right.$ and 4 for PyMT-chOVA;C $\mathrm{Cr} 2^{+/+}$and PyMT-chOVA; $\mathrm{Cr} 2^{-/-}$tumors, respectively). (B) MHC class I is increased on $\mathrm{Ccr} 2^{-/-}$compared with $\mathrm{Ccr}^{+/+}$cancer cells after transplantation into $\mathrm{C} 57 \mathrm{BL} / 6$ hosts during the growth-restricted phase, as determined by immunofluorescence staining (upper panels; scale bar $=50 \mu \mathrm{m}$ ). Quantification of mean pixel count (bottom panel, $n=5)$. (C) MHC class I is unchanged on Ccr2 $2^{+/+}$and $C \mathrm{cr2} 2^{-/-}$cancer cell transplants to athymic hosts, as determined by immunofluorescence staining (upper panels; scale bar $=50 \mu \mathrm{m}$ ). Quantification of mean pixel count (bottom panel, $n=4$ and 5 for $\mathrm{Crr}^{+/+}$and $\mathrm{CCr}^{-/-}$transplants, respectively). (D) PD-L1 is decreased on $\mathrm{Ccr}^{-/-}$cancer cells, as determined by flow cytometry gated on EpCAM ${ }^{+}$cells $(n=5)$. (E) PD-L1 mRNA levels are decreased in cultured $\mathrm{CCr}^{-/-}$cancer cells, but the cells respond equally well to IFN-y treatment as $\mathrm{Ccr} 2^{-1-}$ cancer cells, as determined by qPCR. C Cr2 ${ }^{+/+}$and $\mathrm{Ccr}^{-/-}$cancer cells growing in culture were treated with either $0,0.2,2.0$, or $20 \mathrm{ng} / \mathrm{ml}$ of recombinant IFN- $\mathrm{y}$ for $48 \mathrm{~h}(\mathrm{n}=3$ ). (F) Treatment with four intraperitoneal doses of anti-PD-L1 antibody $\left(200 \mu \mathrm{g} /\right.$ injection) had no significant effect on growth of $\mathrm{Ccr} 2^{+/+}$or $\mathrm{Ccr} 2^{-/-}$tumors in vivo compared with control rat lgG antibody (arrows indicate treatments; $n=20$ tumors for all conditions). Means \pm SEM are indicated. $P$ values were determined by Student's $t$ test (A-E) or Student's $t$ test on day 58 for $C \mathrm{Cr} 2^{+/+}$transplants (black lines in F) and at day 75 for $C \mathrm{cr} 2^{-/-}$transplants (red lines in F). ${ }^{*}, \mathrm{P}<0.05$; ${ }^{* *}$, $\mathrm{P}<0.01 ;{ }^{* * *}, \mathrm{P}<0.001$. N.S., nonsignificant. 
cancer cells, but rather is regulated by the different immune responses between these tumors.

PD-L1 is a potent suppressor of $\mathrm{T}$ cell activation and proliferation and is expressed on many types of cancer cells (Freeman et al., 2000). Expression of PD-L1 was significantly higher on $\mathrm{CCr}^{+/+}$cancer cells than on $\mathrm{CCr}^{-/-}$cancer cells (Fig. 8 D). Since both MHC class I and PD-L1 are IFN- $\gamma$ response genes, we compared Ifn- $g$ mRNA levels during the early tumor phase ( $3 \mathrm{wk}$ after transplantation) and found significantly higher levels of Ifn-g, as well as Cxcl9, in whole tumor lysate from tumors derived from $\mathrm{Ccr}^{-/-}$compared with $\mathrm{Ccr2}^{+/+}$cancer cells by real-time quantitative PCR (RT-qPCR; Fig. S4 A). RNA FISH revealed that the majority of the Ifn-g mRNA was expressed by infiltrating $\mathrm{CD} 8^{+} \mathrm{T}$ cells and that Ifn- $g$ levels were more variable during the growth-restricted phase of tumors than during the early tumor establishment phase (Fig. S4, B-D). In vitro, recombinant IFN- $\gamma$ treatment resulted in similar up-regulation of Pd-ll mRNA levels in $\mathrm{Ccr}^{+/+}$and $\mathrm{Ccr}^{-/-}$cancer cells (Fig. $8 \mathrm{E}$ ). Thus, our data suggest that $\mathrm{Ccr} 2^{-/-}$cancer cells would be able to respond to increased IFN- $\gamma$ levels in the tumor microenvironment by up-regulating PD-L1. Since we see reduced PD-L1 expression on the $\mathrm{Ccr}^{-/-}$cancer cells in vivo in the context of elevated Ifn-g, other factors must repress PD-L1 expression in vivo. Lastly, we tested whether PD-L1 blockade would alleviate immune suppression of the MMTV-PyMT tumors in vivo. However, anti-PD-Ll therapy had no significant effect on the growth of either the $\mathrm{CCr}^{+/+}$tumors or the low PD-L1-expressing $\mathrm{CCr}^{-1-}$ tumors (Fig. 8 F). Thus, although reduced PD-L1 likely contributed to an increased sensitivity to CTLs in tumors from $\mathrm{Ccr2}^{-/-}$cancer cells, targeting PD-L1 expression was insufficient to reduce growth of the $\mathrm{Ccr2} 2^{+/+}$tumors.

\section{Cancer cell CCR2 prevents the infiltration of cross-presenting CD103+ DCs}

We next examined the infiltration levels of immune populations that might be involved in immune suppression in the $\mathrm{Crr} 2^{+/+}$ tumors. There was no difference in $\mathrm{CD}_{11 \mathrm{~b}^{+}} \mathrm{MHC}$ class $\mathrm{II}^{+} \mathrm{F} 4 / 80^{+}$ macrophages between tumors from $\mathrm{CCr}^{+/+}$and $\mathrm{CCr}^{-/-}$cancer cells (Fig. S4 E). There were, however, significantly fewer $\mathrm{CD}_{11 \mathrm{~b}}{ }^{+} \mathrm{MHC}$ class II ${ }^{-}$myeloid cells in tumors from $\mathrm{Ccr}^{-/-}$cancer cells (Fig. S4 F). This population includes subsets of MDSCs, immature myeloid cells with immune-suppressive activity. Specifically, we found fewer granulocytes and granulocytic MDSCs (CD11b ${ }^{+} \mathrm{CD}_{11 c^{-}} \mathrm{Ly}_{6 \mathrm{G}}{ }^{+} \mathrm{Ly} 6 \mathrm{C}^{\text {low }}$ cells) and more inflammatory monocytes and myeloid MDSCs $\left(\mathrm{CD}_{11 \mathrm{~b}^{+} \mathrm{CD} 11 \mathrm{C}^{-} \mathrm{Ly} 6 \mathrm{G}^{-} \mathrm{Ly} 6 \mathrm{C}^{\text {high }}}\right.$ cells) in tumors from $\mathrm{Ccr}^{-/-}$cancer cells than in those from $\mathrm{CCr}^{+/+}$cancer cells (Fig. S4, G and H).

Since DCs are critical for $\mathrm{T}$ cell activation, we performed immunofluorescence for $\mathrm{CD}_{11 \mathrm{C}^{+}}$, a marker of $\mathrm{DCs}$, and observed more infiltrating $\mathrm{CD}_{11 \mathrm{c}^{+}}$cells in the tumors derived from $\mathrm{Ccr2}^{-/-}$ cancer cells than in those derived from $\mathrm{Ccr}^{+/+}$cancer cells (Fig. 9 A). Furthermore, we found more than double the level of $\mathrm{CD}_{103^{+}}$ DCs-a DC subtype that is very proficient in cross-presenting antigens to $\mathrm{CD} 8^{+} \mathrm{T}$ cells-in tumors from $\mathrm{Ccr2}^{-/-}$cancer cells than in those from $\mathrm{CCr}^{+/+}$cancer cells (Fig. 9 B). The number of $\mathrm{CD}_{103^{+}} \mathrm{DCs}$ was also increased in the draining lymph nodes (dLNs) for these tumors (Fig. 9 C). A concern when using a transplant system to evaluate immune response is the potential for an immune reaction toward antigens on the transplanted cells. However, there were also more $\mathrm{CD}_{103^{+}} \mathrm{DCs}$ in the spontaneously developing tumors in MMTV-PyMT; $\mathrm{Crr}^{-/-}$mice than in MMTV-PyMT;Ccr2 ${ }^{+/+}$mice (Fig. S4 I). Using RT-qPCR from whole tumor lysate and a panel of markers previously shown to be enriched in $\mathrm{CD}_{103}{ }^{+} \mathrm{DCs}$ (Broz et al., 2014), we detected more mRNA for Cdllc and from activation markers, including Cd80, Cd86, and Il12b (Fig. 9 D). Consistently, DCs in tumors from $\mathrm{Ccr2}^{-1-}$ cancer cells displayed higher levels of CD86, a surface marker up-regulated on activated DCs as determined by flow cytometry (Fig. $9 \mathrm{E}$ ). The difference in $\mathrm{CD}_{103^{+}} \mathrm{DC}$ numbers was already apparent in the dLNs $2 \mathrm{~d}$ after injection of irradiated cancer cells into the mammary fat pad (Fig. 9 F), suggesting a direct signal from the cancer cells. However, infiltration of $\mathrm{CD}_{103}{ }^{+} \mathrm{DCs}$ was not increased in tumors from $\mathrm{Ccr}^{-/-}$cancer cells in $\mathrm{T}$ cell-deficient, athymic mice (Fig. $9 \mathrm{G}$ ). This finding suggests that a feedback loop between T cells and DCs is critical for $\mathrm{CD}_{103}{ }^{+} \mathrm{DC}$ recruitment to the tumors.

We next asked whether a factor secreted by $\mathrm{CCr}^{-/-}$cancer cells was responsible for DC maturation toward the $\mathrm{CD}_{103^{+}} \mathrm{DC}$ subtype. Indeed, when bone marrow-derived cells (BMDCs) were cultured with conditioned medium from $\mathrm{Ccr}^{-/-}$or $\mathrm{Ccr}^{+/+}$ cancer cells, the total number of DCs was not different, but a significantly higher percentage of $\mathrm{CD}_{11 \mathrm{c}^{+}}$cells was positive for $\mathrm{CD}_{103}{ }^{+}$using conditioned medium from the $\mathrm{Ccr}^{-{ }^{--}}$cells (Fig. 10 A). Furthermore, the percentage of $\mathrm{CD}_{103}{ }^{+} \mathrm{CD}_{11 \mathrm{c}^{+}}$cells also increased when using conditioned medium from $\mathrm{Ccr}^{+/+}$cancer cells that had been treated with the CCR2 inhibitor (Fig. 10 B), whereas adding the CCR2 inhibitor directly to the bone marrow-derived cultures did not by itself increase the percentage of $\mathrm{CD}_{103^{+}}$cells. Both Flt3 ligand and GM-CSF can stimulate $\mathrm{DC}$ maturation toward the $\mathrm{CD}_{103^{+}}$subtype (Broz et al., 2014). Consistently, we found more mRNA for both Flt3l and Csf2 (coding for GM-CSF) in the tumors derived from $\mathrm{Ccr}^{-/-}$cancer cells than from $\mathrm{CCr}^{+/+}$cancer cells by RT-qPCR (Fig. $10 \mathrm{C}$ ). Protein arrays showed that the levels of two CCR2 ligands, CCL2 and CCL12, and most other cytokines were similar between MMTV-PyMT;CCr2 ${ }^{+/+}$and MMTV-PyMT;C $\mathrm{Cr2}^{-/-}$tumors (Fig. S5 A), while IL-16 and granulocyte colony-stimulating factor (G-CSF) were significantly lower in the MMTV-PyMT;CCr2 ${ }^{-/-}$ tumors at the protein level. When secretions from overnight cultures of the cancer cells under serum-free conditions were analyzed, no significant differences were detected (Fig. S5 B). Thus, from these different assays measuring protein and mRNA, Flt3L, G-CSF, and GM-CSF emerged as candidate factors for future functional studies to determine how $\mathrm{CD}_{103}{ }^{+} \mathrm{DC}$ maturation is altered downstream of CCR2 signaling in cancer cells.

Lastly, to test the importance of the $\mathrm{CD}_{103}{ }^{+} \mathrm{DCs}$ in regulating an immune-controlling microenvironment, we transplanted $\mathrm{CCr2}^{-/-}$and $\mathrm{Ccr}^{+/+}$cancer cells into Batf $3^{-/-}$mice, which lack the basic leucine zipper transcription factor ATF-like 3 (BATF3) critical for $\mathrm{CD}_{103}{ }^{+} \mathrm{DC}$ maturation. In these mice, the growth of $\mathrm{CCr}^{-1-}$ cancer cell-derived tumors was restored to that of the $\mathrm{Ccr}^{+/+}$cancer cell-derived tumors (Fig. $10 \mathrm{D}$ ), and as expected, the percentage of infiltrating $\mathrm{CD}_{103^{+}} \mathrm{DCs}$ was significantly reduced (Fig. $10 \mathrm{E}$ ). Furthermore, $\mathrm{CD} 8^{+} \mathrm{T}$ cell infiltration, as well as 
A

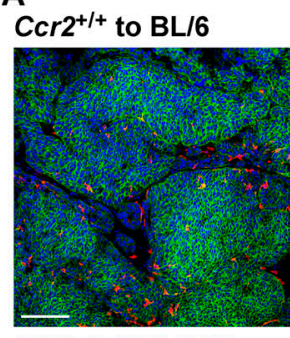

DAPI EpCAM CD11c

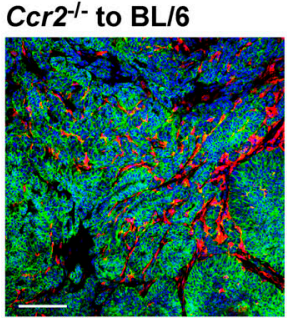

C

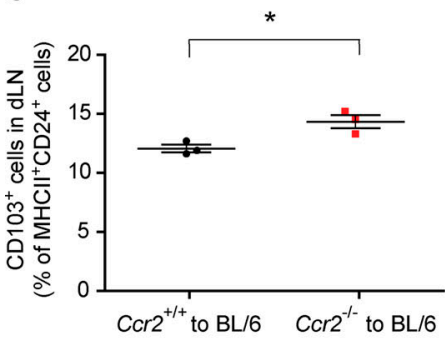

B

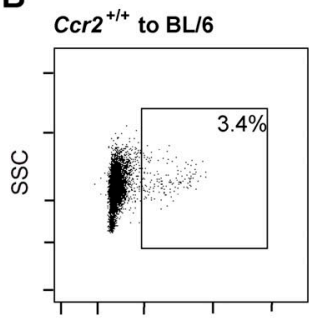

CD103

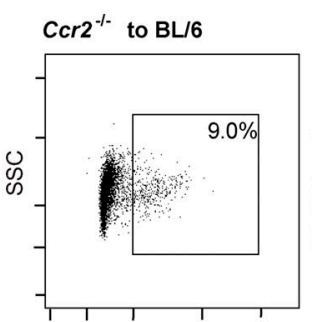

CD103

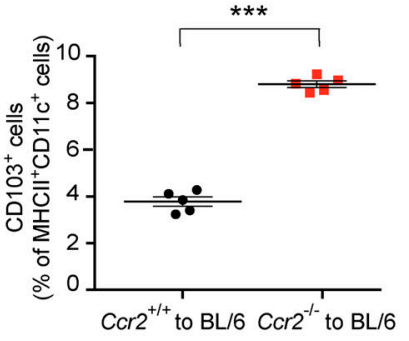

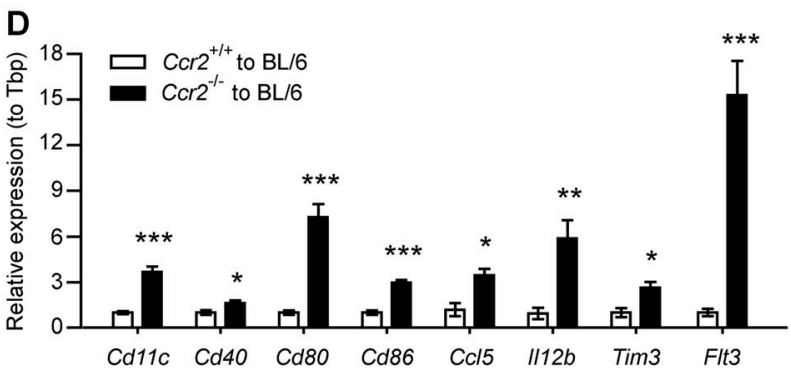

E
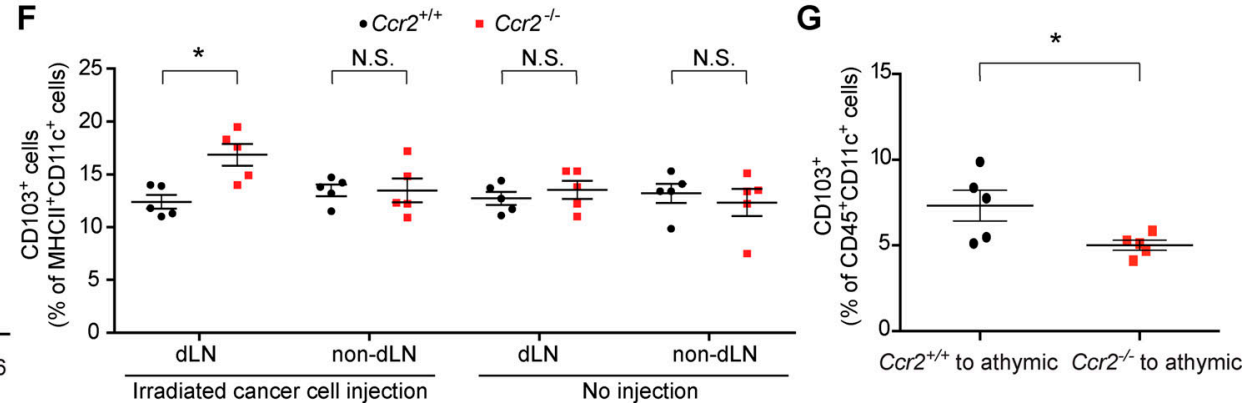

Figure 9. CCr2 ${ }^{-/-}$tumors promote infiltration and activation of cross-presenting $\mathrm{CD}_{103^{+}} \mathrm{DCs}$. (A) Representative immunofluorescence images showing that more $\mathrm{CD}_{11} \mathrm{C}^{+} \mathrm{DCs}$ (red) infiltrated into $\mathrm{Crr}^{-/-}$tumors compared with $\mathrm{Cr}^{+/+}$tumors during the growth-restricted phase $\left(\mathrm{EpCAM}^{+}\right.$, green; scale bar $=100$ $\mu \mathrm{m})$. (B) $\mathrm{CD}_{103^{+}} \mathrm{DCs}$ are increased in $\mathrm{Ccr} 2^{-/-}$tumors compared with $\mathrm{C} \mathrm{Cr} 2^{+/+}$tumors during the growth-restricted phase, as determined by flow cytometry gated on $\mathrm{CD}_{4} 5^{+} \mathrm{CD} 11 \mathrm{c}^{+} \mathrm{MHC}$ class $\mathrm{II}^{+}$cells. SSC, side scatter $(n=5)$. (C) $\mathrm{CD} 103^{+} \mathrm{DCs}$ are increased in the $\mathrm{dLNs}$ of $\mathrm{Ccr}^{-/-}$tumors compared with the dLNs of $\mathrm{Ccr}^{+/+}$tumors during the growth-restricted phase, as determined by flow cytometry gated on $\mathrm{CD}_{4} 5^{+} \mathrm{CD} 11 \mathrm{c}^{+} \mathrm{MHC}$ class $\mathrm{II}^{+}$cells $(n=5)$. (D) Tumors from transplanted $\mathrm{Ccr}^{-/-}$cancer cells have increased DC infiltration and elevated markers of DC activation compared with tumors from $\mathrm{Ccr} 2^{+/+}$cancer cells. RTqPCR on tumors during the growth-restricted phase (for Cd11c, $n=6$ in $\mathrm{Ccr}^{+/+}$and $n=8$ in $\mathrm{Ccr}^{-/-}$; for other genes, $n=5$ in $\mathrm{Crr}{ }^{+/+}$and $n=6$ in CCr2 $2^{-/-}$). (E) DCs in $\mathrm{Crr}^{-/-}$tumors are more activated during the growth-restricted phase, as determined by flow cytometry for $\mathrm{CD}^{2} 6^{+}$gated on $\mathrm{CD} 45^{+} \mathrm{CD} 11 \mathrm{c}^{+} \mathrm{MHC}$ class $\mathrm{II}^{+}$cells $(n=5)$. (F) Flow cytometry on dLNs with or without injection of irradiated cancer cells into the mammary gland. Note that CD103+ $D C s$ are only increased in the dLNs of the glands after injection of $\mathrm{Ccr2}^{-/-}$cancer cells, not in non-dLNs from axillary glands $(n=5)$. (G) CD103 DCs are decreased in Ccr2 ${ }^{-/-}$tumors compared with $\mathrm{Ccr2}^{+/+}$tumors in athymic hosts, as determined by flow cytometry gated on $\mathrm{CD}_{4} 5^{+} \mathrm{CD} 11 \mathrm{c}^{+}$cells $(n=5)$. Means $\pm \mathrm{SEM}$ are indicated. $\mathrm{P}$ values were determined by Student's $t$ test. ${ }^{*}, \mathrm{P}<0.05 ;^{* *}, \mathrm{P}<0.01{ }^{* * *}, \mathrm{P}<0.001$. N.S., nonsignificant.

expression of CD107a and PD-1 by the T cells, was reduced in tumors derived from $\mathrm{Ccr} 2^{-/-}$cancer cells transplanted into Bat $3^{-1-}$ mice (Fig. 10, F-H). These findings support the notion that $\mathrm{CD}_{103}{ }^{+} \mathrm{DC}$ and $\mathrm{CD} 8^{+} \mathrm{T}$ cells act together to regulate tumor immunity.

\section{Discussion}

The tumor-promoting effects of CCR2 are well documented. However, they have mostly been attributed to CCR2-expressing immune and other host cells (Lim et al., 2016; Nakasone et al., 2012; Qian et al., 2009, 2011; Wolf et al., 2012). Yet, CCR2 is also expressed by breast cancer cells and possibly up-regulated compared with normal breast epithelial tissue in a subset of breast cancers, and such expression has been correlated with shortened survival (Labovsky et al., 2017). The expression of CCR2 by cancer cells has been proposed to promote tumor growth through increased motility and invasion, cell proliferation, and cell survival (Fang et al., 2012; Hu et al., 2019; Lu et al., 2006). Here, we showed that in the MMTV-PyMT mouse model, CCR2 signaling in cancer cells helps breast tumors establish a locally immune-suppressive microenvironment. Compared with tumors from $\mathrm{Ccr}^{+/+}$cancer cells, the tumors from $\mathrm{Ccr2}^{-/-}$cancer cells have higher infiltration of $\mathrm{CD}_{103^{+}} \mathrm{DCs}$ and activated $\mathrm{CD} 8^{+}$ $\mathrm{T}$ cells, as well as lower infiltration of granulocytic MDSCs. Furthermore, the $\mathrm{Ccr2}^{-1-}$ cancer cells have higher surface levels of MHC class I and lower levels of PD-L1. It is likely the combination of all of these changes that results in more effective 
A
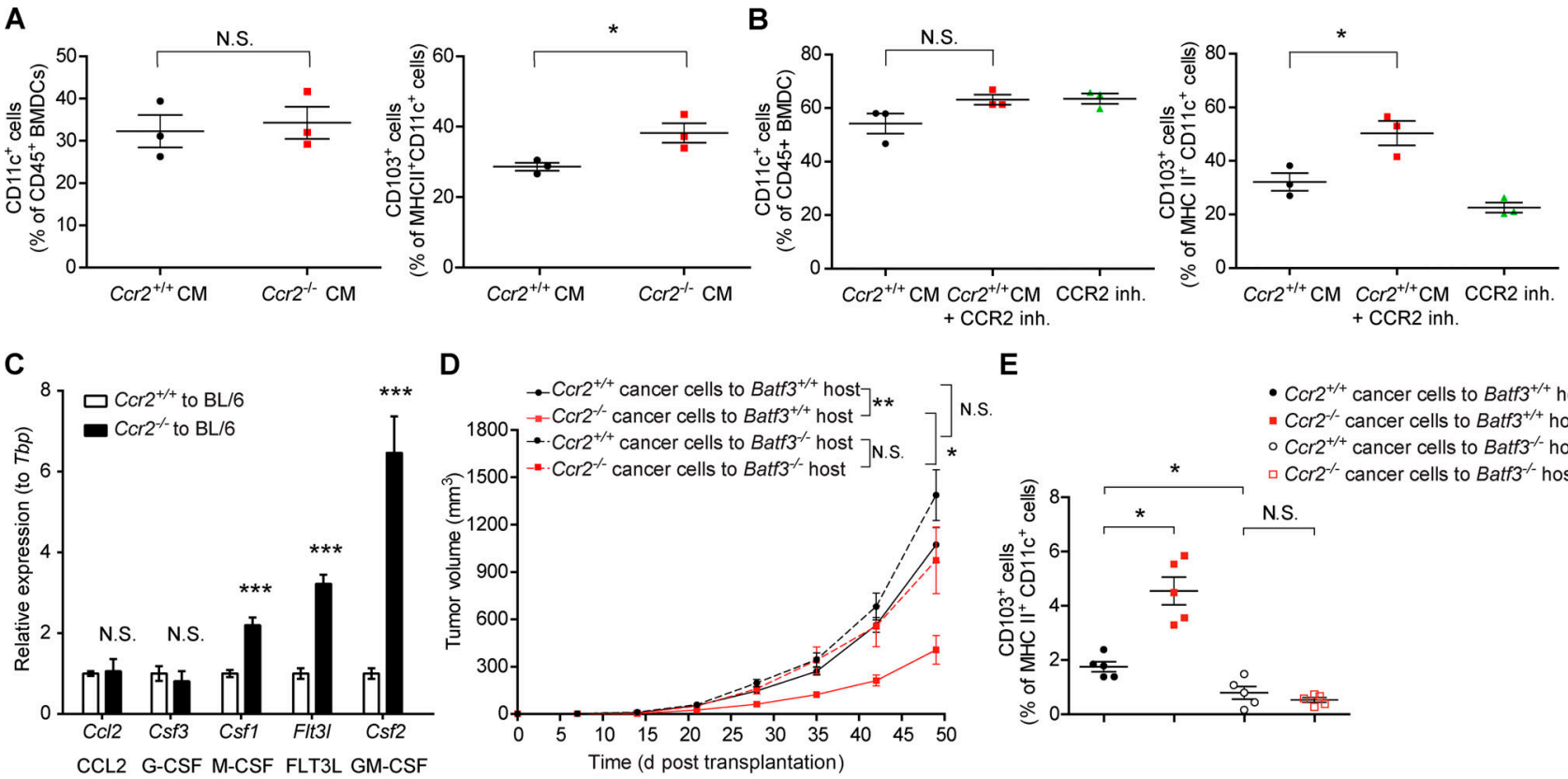

D

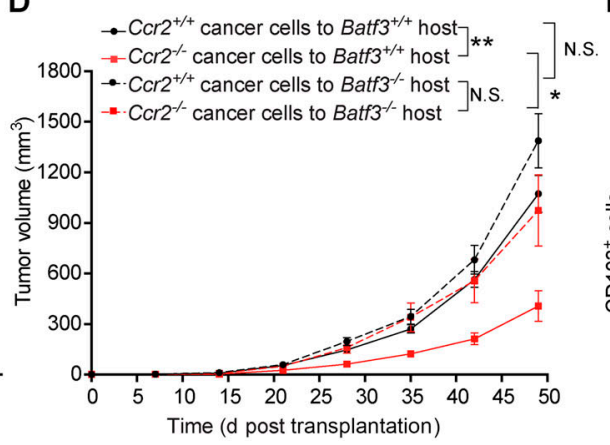

E
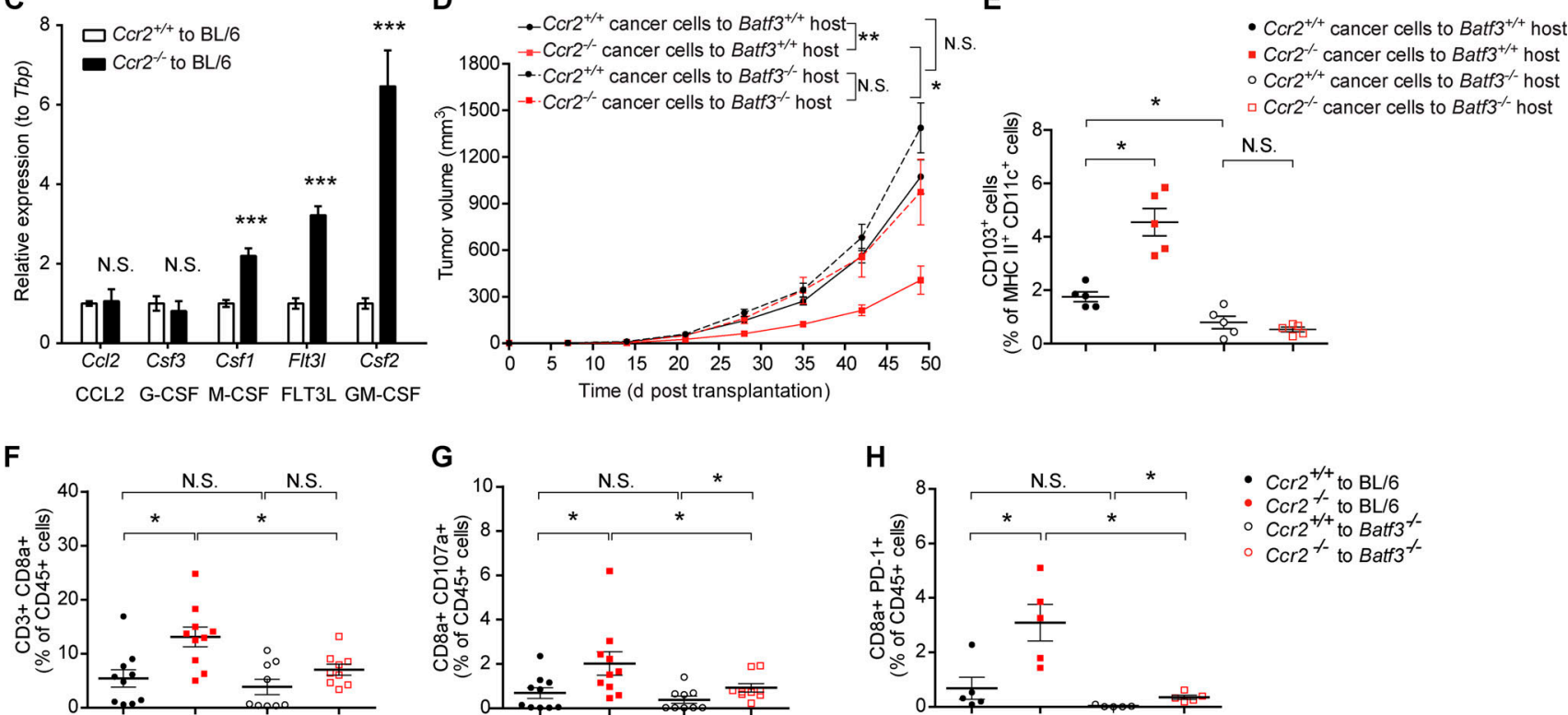

G

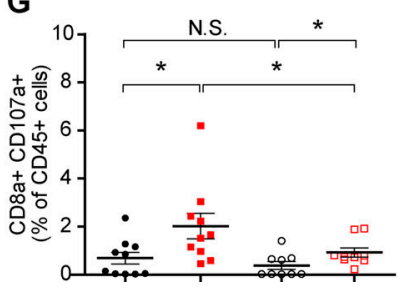

H

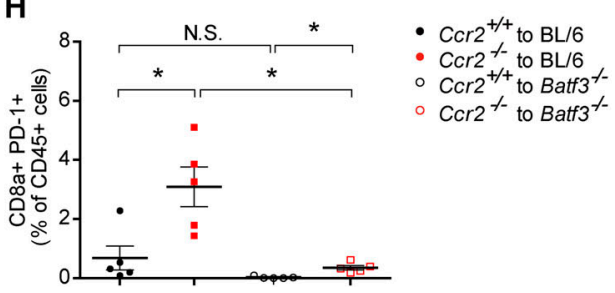

Figure 10. Cross-presenting $\mathrm{CD}_{103^{+}} \mathrm{DCs}$ are critical for immune control of $\mathrm{Ccr2}^{-/-}$cancer cells. (A) Conditioned medium from $\mathrm{Ccr} 2^{-/-}$cancer cells induces similar numbers of CD11c DCs (left) but more CD103+ BMDCs (right) in vitro compared with conditioned medium from $\mathrm{Ccr} 2^{+/+}$cancer cells $(n=3)$. (B) Conditioned medium from $\mathrm{Ccr}^{+/+}$cancer cells cultured with CCR2 inhibitor (inh.) induced similar numbers of CD11c DCs (left) but more CD103+ BMDCs (right) in vitro than conditioned medium from control cells cultured in the absence of the inhibitor medium $(n=3)$. (C) Tumors from transplanted $C \mathrm{cr} 2^{-/-}$cancer cells have elevated Csf2 mRNA (coding GM-CSF) and Flt3l (coding FLT3 ligand) but not Ccl2 or Csf3 compared with tumors from Ccr2 ${ }^{+/+}$cancer cells. RT-qPCR on tumors from transplanted $\mathrm{Crr}^{+/+}$and $\mathrm{Ccr}^{-/-}$cancer cells during the growth-restricted phase $\left(n=5\right.$ or 6 for $\mathrm{Ccr}^{+/+}$tumors, and $n=6$ for $\mathrm{Ccr} 2^{-/-}$tumors). (D) Tumor growth is increased in Batf3 $3^{-/-}$hosts transplanted with $\mathrm{Ccr} 2^{-/-}$cancer cells, as determined by weekly caliper measurements ( $n=9$ in $\mathrm{Ccr2} 2^{+/+}$to Batf $3^{-/-}$hosts group, and $n=10$ for the other three groups). (E) CD103 ${ }^{+} \mathrm{DCs}$ are increased in $\mathrm{Crr} 2^{-/-}$tumors compared with $\mathrm{CCr} 2^{+/+}$tumors in $\mathrm{C} 57 \mathrm{BL} / 6$ hosts

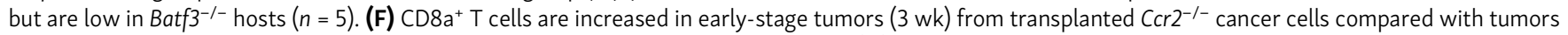
from $\mathrm{Ccr2}^{+/+}$cancer cells in C57BL/6 hosts but are low in Batf3-/- hosts $(n=9$ or 10). (G) Lamp-1 (CD107a) and CD8a double-positive T cells are increased in early-stage tumors ( $3 \mathrm{wk}$ ) from transplanted $\mathrm{Ccr} 2^{-/-}$cancer cells compared with tumors from $\mathrm{Ccr} 2^{+/+}$cancer cells but are low in Batf3 $3^{-/-}$hosts $(n=9$ or 10$)$. ( $\mathrm{H}$ ) PD-1 and CD8a double-positive T cells are increased in early-stage tumors (3 wk) from transplanted $\mathrm{Ccr}^{-/-}$cancer cells compared with tumors from Ccr2 ${ }^{+/+}$ cancer cells in C57BL/6 hosts but are low in Batf $3^{-/-}$hosts $(n=5)$. Means \pm SEM are indicated. P values were determined by Student's $t$ test $(A-C$ and $E-H)$ or one-way ANOVA, followed by Sidak's multiple comparisons test at the end time point (D). ${ }^{*}, \mathrm{P}<0.05 ;{ }^{* *}, \mathrm{P}<0.01 ;{ }^{* * *}, \mathrm{P}<0.001$. N.S., nonsignificant.

immune surveillance of the $\mathrm{Ccr} 2^{-/-}$cancer cells and reduced growth of tumors from these cells. To our knowledge, the ability of cancer cell CCR2 signaling to orchestrate tumor immune suppression has not previously been recognized.

Among the most notable changes in the tumor immune microenvironment caused by targeting cancer cell $\mathrm{Ccr} 2$ were the increased levels of both $\mathrm{CD}_{103^{+}} \mathrm{DCs}$ and $\mathrm{CD} 8^{+} \mathrm{T}$ cells in tumors, and the infiltration of these two cell populations was apparently connected. In athymic mice lacking mature $\mathrm{CD} 8^{+}$cells, the $\mathrm{CD}_{103^{+}} \mathrm{DC}$ infiltration was no longer elevated in tumors derived from $\mathrm{Ccr}^{-/-}$cancer cells compared with those from $\mathrm{Crr}^{+/+}$ cancer cells. Conversely, in Batf $3^{-/-}$mice, which lack the transcription factor BATF3 required for $\mathrm{CD}_{103^{+}}$DC development, $\mathrm{CD}^{+} \mathrm{T}$ cell infiltration was equally low for tumors from $\mathrm{Ccr} 2^{+/+}$ and $\mathrm{Crr}^{-/-}$cancer cells. These observations are consistent with several other recent reports intimately linking the function of $\mathrm{CD} \mathrm{C3}^{+} \mathrm{DCs}$ and $\mathrm{CD} 8^{+} \mathrm{T}$ cells in tumors. First, $\mathrm{CD} 103^{+} \mathrm{DCs}$ have been shown to secrete chemokines mediating $\mathrm{T}$ cell infiltration, including CXCL9 and -10 (de Mingo Pulido et al., 2018; Spranger et al., 2017). Second, secretion of IL-12 from $\mathrm{CD}_{103}{ }^{+} \mathrm{DCs}$ has been shown to stimulate $\mathrm{CD} 8^{+} \mathrm{T}$ cell function (Ruffell et al., 2014). Our data support these previous studies, showing not only a link between $\mathrm{CD} 13^{+} \mathrm{DC}$ and $\mathrm{CD}^{+} \mathrm{T}$ cell infiltration but also increased $\mathrm{Cxcl} 9$ and Il-12b mRNA in tumors derived from $\mathrm{Ccr}^{-1-}$ cancer cells. Altogether, these data support previous work showing that the regulation of $\mathrm{CD}_{103}{ }^{+} \mathrm{DC}$ infiltration is a critical step in tumor immune surveillance (Broz et al., 2014; Meyer et al., 2018; Roberts et al., 2016). 
Our data suggest that CCR2 signaling regulates the secretion of a factor from the cancer cells that affects the polarization of DCs to the $\mathrm{CD}_{103}{ }^{+}$subtype. Several factors have been proposed to induce the polarization of $\mathrm{CD}_{103}{ }^{+} \mathrm{DCs}$, including Flt3L and GM-CSF (Mayer et al., 2014), and consistently, mRNA levels for both of these factors were higher in tumors from $\mathrm{Ccr}^{-/-}$cancer cells than in those from $\mathrm{Ccr}^{+/+}$cancer cells. However, it is unclear if Flt3L and GM-CSF could be solely responsible for the difference in $\mathrm{CD}_{103}{ }^{+} \mathrm{DC}$ infiltration between tumors from $\mathrm{CCr}^{+/+}$or from $\mathrm{CCr}^{-/-}$cancer cells. A recent study reported that G-CSF secreted from MMTV-PyMT cancer cells can inhibit the differentiation of $\mathrm{CD}_{103}{ }^{+}$DCs by down-regulating IFN regulatory factor-8 in DC progenitors (Meyer et al., 2018). Interestingly, G-CSF was reduced in MMTV-PyMT;CCr2 ${ }^{-1-}$ tumors compared with MMTV-PyMT;C $\mathrm{Cr}^{+/+}$tumors, although secretion of G-CSF from isolated cancer cells was not reduced, suggesting that altered secretion is not a direct effect of CCR2 signaling in cancer cells.

$\mathrm{Ccr}{ }^{-/-}$cancer cells had distinct expression of several genes, including many that were consistent with an IFN response. Among these, increased surface expression of MHC class I might explain why $\mathrm{Ccr}^{-/-}$cancer cells are more sensitive to $\mathrm{T}$ cellmediated killing than $\mathrm{CCr}^{2++}$ cancer cells. However, since $\mathrm{Ccr} 2^{+/+}$ cancer cells did not down-regulate MHC class I in T celldeficient, athymic mice, we speculate that MHC class I expression is not directly regulated by CCR2 signaling in the cancer cells. Rather, the altered expression of IFN response genes, including MHC class I, may be an indirect result of an immune response in the tumors. Altogether, we propose that the cancer cells act on $\mathrm{CD}_{103^{+}} \mathrm{DCs}$, leading to a feedback loop between $\mathrm{CD}_{103^{+}} \mathrm{DCs}$ and $\mathrm{CD} 8^{+} \mathrm{T}$ cells-two immune cell types with highly interconnected functions.

Our study has several translational implications. First, our findings provide a possible explanation as to why patients with high CCR2 expression in breast cancer cells have a shortened survival time compared with patients with low/negative CCR2 expression (Labovsky et al., 2017). Second, results from an openlabel nonrandomized phase I trial using a CCR2 inhibitor against locally invasive pancreatic cancer suggest that the inhibitor enhanced chemotherapy response, reduced macrophage infiltration, and induced an anti-tumor adaptive immune response (Nywening et al., 2016). Our data suggest that the potential clinical benefits of CCR2 inhibitors might be caused by the combined inhibition of CCR2 signaling in both stromal and cancer cells. Interestingly, the loss of even one Ccr2 allele was sufficient to reduce tumor growth in our study, suggesting that partial inhibition of CCR2 could result in clinical benefit. It is unclear why $\mathrm{Ccr}^{+/-}$cancer cells phenocopy the $\mathrm{Ccr}^{-/-}$cancer cells, but this phenomenon could be due to reduced dimerization of CCR2 in $\mathrm{Ccr2}^{+/-}$cancer cells, consistent with a prior report (Rodríguez-Frade et al., 1999), or because surpassing a threshold level of CCR2 signaling is required to induce immune suppression. Finally, recombinant G-CSF and GM-CSF are routinely given with certain types of chemotherapy to support the bone marrow and reduce the risk of lethal febrile neutropenia (Mehta et al., 2015). Our data support prior studies suggesting that these cytokines play complex roles in regulating the immune response against tumors: they appear to have opposing effects on $\mathrm{CD}_{103^{+}}$ DC differentiation, with GM-CSF stimulating $\mathrm{CD}_{103}{ }^{+} \mathrm{DC}$ differentiation (Greter et al., 2012; Mayer et al., 2014) and G-CSF inhibiting it (Meyer et al., 2018). Although GM-CSF secretion in the tumor microenvironment potentially enhances immune responses against tumors by stimulating $\mathrm{CD}_{103^{+}} \mathrm{DC}$ differentiation, this cytokine can also mobilize immune-suppressive MDSCs, leading to suppression of an anti-tumor immune response (Bayne et al., 2012; Pylayeva-Gupta et al., 2012). Therefore, exploring other approaches than administration of recombinant GM-CSF and G-CSF to specifically boost $\mathrm{CD}_{103^{+}} \mathrm{DC}$ maturation could be an important future translational direction, and determining the exact mechanism that causes inhibition of cancer cell CCR2 signaling to promote $\mathrm{CD}_{103^{+}}$maturation may provide insights into how this process occurs.

We found that tumor onset was similar between MMTVPyMT;C $\mathrm{Cr}^{+/+}$and MMTV-PyMT;CCr2 $2^{-/-}$mice, while tumor growth was slower in MMTV-PyMT;Ccr2 ${ }^{-/-}$mice. These data are very similar to a prior report studying tumor growth in MTMV-Neu mice, where mice null for $\mathrm{Ccl} 2$, the ligand for CCR2, also had similar tumor onset yet reduced tumor growth rates, as did mice treated with a CCR2 inhibitor (Chen et al., 2016b). However, unexpectedly, MMTV-Neu mice lacking Ccr2 had accelerated, not reduced, tumor growth in this study, and the authors speculated that this could be due to abnormal differentiation of the monocytes in these mice or unintentional effects of the genetic targeting of $\mathrm{C} c r 2$. There are several possible explanations for the difference between our result using MMTV-PyMT;Ccr2 ${ }^{-/-}$mice and that of the MMTV-Neu;Ccr2 ${ }^{-/-}$ mice in the previous publication. First, tumors of MMTV-PyMT mice have more stromal components than tumors of MMTVNeu mice. Second, the genetic background of the mice used in our experiments was C57BL/6, while it was BALB/c in the case of the MMTV-Neu model. Finally, our tumor transplantation experiments strongly suggest that the tumor growth phenotype in our model is caused by CCR2 expression by cancer cells, but it is not clear whether cancer cells in the MMTV-Neu model express CCR2 or whether the phenotype is due to effects from stromal cells.

Despite the data suggesting that CCR2 inhibition has beneficial effects in cancer treatment, some studies have raised serious concerns about targeting the CCR2 ligand. Cessation of anti-CCL2 therapy resulted in increased pulmonary metastasis and decreased survival in a murine model of breast cancer due to rapid mobilization of CCR2-expressing monocytes into the circulation immediately upon cessation of therapy (Bonapace et al., 2014). Therefore, CCR2 inhibition likely will have to be used in combination with other therapies to maximize the eradication of existing cancer cells and to avoid complications of discontinuing the inhibition. In summary, the divergent results across mouse models, genetic backgrounds, and variable experimental approaches to targeting CCL2 or CCR2 suggest that the effects of targeting this axis can depend on tumor subtype, genetic background, and cell types.

Our findings support the notion that the CCL2/CCR2 axis is an immune modulatory pathway in cancer, but with the added layer of complexity that cancer cells can hijack this chemokine 
receptor pathway to orchestrate immune suppression. In this study, we focused on characterizing the cellular mechanisms responsible for the novel link between cancer cell CCR2 signaling and tumor immune suppression. Preclinical experiments suggest that CCR2 targeting strategies can have detrimental effects, including the promotion of metastasis (Bonapace et al., 2014; Li et al., 2013). Although we observed no effect of anti-PD-L1 antibodies in combination with CCR2 deletion in cancer cells, anti-PD-L1 antibodies in combination with CCR2 inhibition (which also targets CCR2 on myeloid cells) reduced MDSC infiltration and increased survival in a mouse model of glioma (Flores-Toro et al., 2020). Therefore, future work that identifies the precise mechanisms by which CCR2 signaling in cancer cells induce immune suppression in breast cancer may set the stage for developing novel immune modulatory therapies. There are ongoing clinical trials using pharmacological inhibitors of CCR2 in cancer patients, and our data suggest that the potential effects of inhibiting CCR2 signaling in cancer cells should be taken into account when interpreting the results from these trials.

\section{Materials and methods}

\section{Mice}

$\mathrm{Ccr2}^{-/-}$, Batf3 $3^{-/-}$, and OT-1 mice (all on a C57BL/6 background) were obtained from Jackson Laboratory, and athymic $(\mathrm{Nu} / \mathrm{Nu})$ mice were obtained from Charles River Laboratory. MMTVPyMT mice (on C57BL/6 [referred to as BL/6] background) were bred at Cold Spring Harbor Laboratory (CSHL), and MMTV-PyMT-chOVA mice (Engelhardt et al., 2012) were a kind gift from Dr. Mathew Krummel (University of California, San Francisco, San Francisco, CA). MMTV-PyMT and PyMT-chOVA mice were intercrossed with $C \mathrm{cr} 2^{-/-}$mice. MMTV-PyMT;C Cr2 ${ }^{+/+}$ and MMTV-PyMT;Ccr2 $2^{-/-}$mice, and similarly MMTV-PyMTchOVA;Cr2 $2^{+/+}$and MMTV-PyMT-chOVA;Ccr2 ${ }^{-/-}$mice, were from the same mouse colony (mice were littermates, or their parents were littermates). All the BL/6 host mice were purchased from Jackson Laboratory. All animal experiments were approved by the Institutional Animal Care and Use Committee (IACUC) at CSHL and were conducted in accordance with the National Institutes of Health Guide for the Care and Use of Laboratory Animals.

\section{Measurement of in vivo tumor growth and lung metastasis}

Tumor onset was determined by weekly palpation. Once a tumor was detected, its size was measured weekly by caliper, and tumor volume was calculated as (length $\times$ width $\left.^{2}\right) / 2$. For primary tumor growth, mice were either sacrificed at endpoint, when tumors reached $20 \mathrm{~mm}$ or ulcerated (whichever came first), or at indicated time points (early phase: $3 \mathrm{wk}$ after transplantation; growth-restricted phase: 5-6 wk after transplantation). For the lung metastasis assay, mice were sacrificed at either of two IACUC-approved endpoints (when tumors reached $25 \mathrm{~mm}$ or ulcerated). To determine metastatic burden, we adapted a previously published method (Nielsen et al., 2001). Briefly, lungs were placed in $4 \%$ paraformaldehyde (PFA) in PBS in a vacuum desiccator for $1 \mathrm{~h}$. The lungs remained in $4 \%$ PFA at $4^{\circ} \mathrm{C}$ for $48 \mathrm{~h}$, followed by incubation in $20 \%$ sucrose in PBS at $4^{\circ} \mathrm{C}$ for $48 \mathrm{~h}$. Lungs were embedded in Tissue-Tek optimal cutting temperature compound embedding solution (Sakura). The blocks were then placed in a custom-made cutting chamber with razor blade inserts every $2 \mathrm{~mm}$, and the block was cut into 2-mm sections. These sectioned lung pieces were then reembedded in fresh optimal cutting temperature compound to allow for crosssectional cuts from the entire lung tissue. These cross sections of the lungs were stained with H\&E and scanned by an Aperio ScanScope CS System (Leica Biosystems). The metastatic burden was calculated as the percentage of metastasis/lung area and the number of foci/lung area, determined using Aperio eSlide Capture Devices software (Leica Biosystems). Histology was evaluated by pathologist J.E. Wilkinson and scored as percentage of solid areas of tumors.

\section{Primary cancer cell isolation, culture, and transplantation}

Aged-matched virgin females (C57BL/6, $\mathrm{Ccr}^{-/-}, \mathrm{Batf3}^{-/-}$, or $\mathrm{Nu} /$ $\mathrm{Nu}$ ) 6-12 wk of age were used as hosts for transplantation. Cancer cells were isolated from two or three tumors, each one 8-10 $\mathrm{mm}$ in diameter, from MMTV-PyMT;C Cr2 ${ }^{+/+}$or MMTVPyMT;CCr2 ${ }^{-/-}$mice. Tumors were mechanically dissociated and digested for $1 \mathrm{~h}$ with $1 \times$ collagenase/hyaluronidase (10X Solution; Stem Cell Technology) containing DNase I ( $2 \mathrm{U} / \mathrm{ml}$; Roche) in Roswell Park Memorial Institute (RPMI)-1640 medium supplemented with 5\% FBS (VWR Life Science Seradigm). Single cells and debris were removed from the resulting carcinoma organoid preparation by pulse centrifugation in HBSS supplemented with $5 \%$ FBS. Purified carcinoma organoids were dissociated into single-cell suspension in $0.05 \%$ trypsin with $0.1 \%$ EDTA supplemented with $2 \mathrm{U} / \mathrm{ml}$ of DNase I for 2-3 min. Single tumor cells were passed through a $100-\mu \mathrm{m}$ cell strainer (BD Biosciences) and either plated in RPMI-1640 supplemented with $10 \%$ FBS for in vitro experiments or washed with PBS and immediately injected into the inguinal mammary glands of host mice (2.5 $\times 10^{5}$ in $20 \mu \mathrm{l}$ of 1:1 PBS/Matrigel; Corning).

To evaluate the effect of cancer cell Ccr2 on the anti-tumor immune response locally versus systemically, contralateral transplantation was conducted with cancer cells with different Ccr2 genotypes transplanted into each inguinal mammary gland $\left(2.5 \times 10^{5}\right.$ in $20 \mu \mathrm{l}$ of $1: 1 \mathrm{PBS} /$ Matrigel $)$. Cancer cells were isolated as described above, and both C57BL/6 and $\mathrm{Ccr}^{-/-}$mice were used as hosts.

To transplant irradiated cancer cells, freshly isolated primary MMTV-PyMT;CCr2 ${ }^{+/+}$or MMTV-PyMT;C Cr2 ${ }^{-/-}$cancer cells were plated in a $10-\mathrm{cm}$ Petri dish $\left(2 \times 10^{6}\right.$ per dish) in RPMI with $10 \%$ FBS and received $80 \mathrm{~Gy}$ of irradiation in the Gammacell 40 Exactor (Best Theratronics). After irradiation, cancer cells were washed with PBS and injected into the inguinal mammary glands of host mice $\left(2.5 \times 10^{5}\right.$ in $20 \mu \mathrm{l}$ of PBS). To generate cancer cell-conditioned medium, primary cancer cells from either MMTVPyMT;CCr2 ${ }^{+/+}$or MMTV-PyMT;CCr2 ${ }^{-/-}$tumors were plated in a $10-\mathrm{cm}$ dish $\left(2 \times 10^{6}\right.$ per dish $)$ in DMEM/F12 medium plus $10 \%$ FBS and $1 \%$ penicillin/streptomycin, with or without CCR2 antagonist (RS504393; $10 \mu \mathrm{M}$; Sigma-Aldrich) for $2 \mathrm{~d}$. The conditioned medium was collected and centrifuged at $300 \times \mathrm{g}$ for $10 \mathrm{~min}$, and the supernatant was used in experiments. 


\section{In vivo antibody treatment}

Tumor cells from MMTV-PyMT;Ccr2 $2^{+/+}$or MMTV-PyMT;CCr2 $2^{-/-}$ mice were transplanted as described above. For anti-PD-L1 treatment, on days 15, 18, 21, and 24 after transplantation (after tumors had formed), mice received $200 \mu \mathrm{g}$ of anti-PD-L1 antibody by intraperitoneal injection (Clone 10F.9G2; Bio X Cell) or control rat IgG2b antibody (Bio X Cell; Winograd et al., 2015). For $\mathrm{CD}^{+} \mathrm{T}$ cell depletion, mice were injected intraperitoneally with $200 \mu \mathrm{g}$ of anti-CD8a antibody (Clone 2.43; BE0061; Bio X Cell) or control rat IgG2b antibody (Clone LTF-2; BE0090; Bio X Cell) every $3 \mathrm{~d}$ starting from day 0 and until day 30 . Tumor size was measured biweekly, and mice were sacrificed at the IACUC-approved endpoint.

\section{Flow cytometry}

Tumors were harvested and mechanically dissociated for $30 \mathrm{~min}$ with collagenase D ( $2 \mathrm{mg} / \mathrm{ml}$; Sigma-Aldrich) and DNase I (4 $\mathrm{U} / \mathrm{ml}$ ) in RPMI. For flow cytometry of cells from lymph nodes, the lymph nodes were forced through a $100-\mu \mathrm{m}$ cell strainer, and flow-through cells were collected for experiments. Cells were resuspended in $1 \times$ HBSS supplemented with $0.5 \%$ BSA and centrifuged at $300 \times g$. The cell suspension was filtered through a $70-\mu \mathrm{m}$ cell strainer, and red blood cells were lysed using red blood cell lysing buffer (Sigma-Aldrich) for $1 \mathrm{~min}$ at room temperature.

For flow cytometry staining, cells $\left(1 \times 10^{6}\right)$ were incubated with mouse Fc Block (clone 2.4G2; BD Biosciences) for 10 min on ice, and then stained with the appropriate antibodies to surface markers at $4^{\circ} \mathrm{C}$ for $30 \mathrm{~min}$ in the dark or permeabilized and stained with intracellular antibodies overnight (see below for antibodies). Cell viability stain Zombie Red (BioLegend) was used to differentiate between dead and live cells. The stained populations were analyzed using an LSR II flow cytometer (BD Biosciences; see Fig. S2 for gating strategies) and FlowJo software (Version 10; BD Biosciences). Antibodies: CD45-eFluor 450 (Clone 30-F11), CD11c-PE-Cy7 (Clone N418), MHC II (I-A/IE)-APC-eFlour780 (Clone M5/114.15.2), CD103-FITC (Clone 2E7), CD274 (B7-H1, PD-L1)-PE-Cy7 (Clone MIH5), CD3-FITC (Clone 17A2), CD8-eFluor450 (Clone 53-6.7), CD107a (LAMP-1)-PE (Clone 1D4B), IFN- $\gamma-P E$ (Clone XMG1.2), Granzyme B-FITC (Clone NGZB), $\gamma \delta$ TCR-PE-Cy5 (Clone GL3), and FoxP3-PE (Clone NRRF30) were all from eBioscience; CD4-PerCP-Cy5.5 (Clone BM9), CD69-PE (Clone H1.2F3), F4/80-PerCP-Cy5.5 (Clone BM9), MHC I (H-2)-PE (Clone M1/42), CD326 (EpCAM)-APC (Clone G8.8), and CD86-BV510 (Clone GL-1) were all from BioLegend; CD45-APC (Clone 30-F11), Ly6G-FITC (Clone 1A8), and CD11b-PE (Clone M1/ 70) were from BD Biosciences; EpCAM-APC (Clone CI:A3-1) was from AbD Serotec; and CCR2-flourescein (Clone 475301) was from R\&D Systems. Prior to Granzyme B staining, cells were incubated for $2 \mathrm{~h}$ with Brefeldin A (\#B6542; Sigma-Aldrich).

\section{Cytokine array}

Tumors (8-10 $\mathrm{mm}$ in diameter) were isolated from MMTVPyMT;CCr2 ${ }^{+/+}$and MMTV-PyMT;CCr2 ${ }^{-/-}$mice and immediately snap-frozen in liquid nitrogen. They were then homogenized in PBS with the addition of protease inhibitors (Promega). Proteome Profiler Mouse Cytokine Array Kit, Panel A
(R\&D Systems) was used according to the manufacturer's instructions. Films were scanned, and spots were analyzed using ImageJ software.

\section{MTS (3-[4,5-dimethylthiazol-2-yl]-5-[3-carboxymethoxyphenyl]- 2-[4-sulfophenyl]-2H-tetrazolium) assay}

Proliferation of cancer cells isolated from MMTV-PyMT;CCr2 $2^{+/+}$ and MMTV-PyMT;Ccr2 ${ }^{-/-}$mice was measured using the CellTiter 96 AQueous One Solution Cell Proliferation Assay (MTS; Promega) according to the manufacturer's instructions. In this assay, the MTS tetrazolium compound (Owen's reagent) was bioreduced by metabolically active cells into a colored formazan product. The quantity of formazan product was measured in a 96-well plate by absorbance at $490 \mathrm{~nm}$.

\section{RNA purification and RT-qPCR analysis}

Total RNA from cancer cells (cultured $48 \mathrm{~h}$ in RPMI supplemented with $10 \% \mathrm{FBS}$ ) or primary tumors was extracted using an RNAeasy kit (Qiagen), following the manufacturer's instructions. RNA was quantified using a Nanodrop 2000 spectrophotometer (Thermo Fisher Scientific). Reverse transcription was performed with an ImProm-II Reverse Transcription System (Promega) for the cancer cells or the RevertAid First Strand cDNA Synthesis system (K1622; Thermo Fisher Scientific) for the primary tumors, with the following cycling conditions: $5 \mathrm{~min}$ at $70^{\circ} \mathrm{C}, 10 \mathrm{~min}$ at $4^{\circ} \mathrm{C}, 5 \mathrm{~min}$ at $25^{\circ} \mathrm{C}, 60 \mathrm{~min}$ at $42^{\circ} \mathrm{C}$, and $15 \mathrm{~s}$ at $70^{\circ} \mathrm{C}$ using $1 \mu \mathrm{g}$ total RNA extract for $20 \mu \mathrm{l}$ of final volume. RT-qPCR analysis was performed using a TaqMan gene expression assay (Thermo Fisher Scientific) with the following specific primers: Ccr2: Mm00438270_ml; Pd-l1: Mm00452054_ml; Cd8a: Mm01182107_gl; Ifn-g: mm01168134_ml; Pd-1: mm01285676_ ml; Gzmb: mm00502528_m1; Ctla4: mm00486849_ml; Prf1: mm00812512_ml; Clec9a: mm00554956_ml; Cxcl9: mm00434946_ ml; Cxcl10: mm00445235_ml; Cxcr3: mm00438259_ml; Cxcr4: Mm01996749_sl; Cdllc: mm00498698_ml; Cd40: mm00441891_ml; Cd80: mm00711660_ml; Cd86: mm00444543_ml; Ccl5: mm01302427_ m1; Il-12b: mm01288989_m1; Tim3: mm00454540_m1; Csf2: mm01290062_ml; Flt3l: mm00442801_ml; Flt3: mm00439016_ m1; Ccl2: mm00441242_m1; Csf3: mm00438334_m1; Csf1: mm00432686_m1; and Tbp: mm01277042_m1.

For cancer cells, RT-qPCR was performed on three independently isolated cancer cell populations and in triplicate for each sample. To determine the effects of IFN- $\gamma$ on $P d-l 1$ expression, cancer cells were cultured with the indicated concentration of IFN- $\gamma$ (\#485-MI-100; R\&D Systems) for $48 \mathrm{~h}$ before isolation of RNA. For tumor samples, RT-qPCR was performed on at least five primary tumors from different mice and in triplicate for each sample. Relative quantitation was performed with the $2^{(-\Delta \Delta C T)}$ method using $\beta$-Actin or Tbp expression for normalization and MMTV-PyMT;CCr2 ${ }^{+/+}$cancer cells or tumor samples as a reference sample.

\section{RNA in situ hybridization (ISH)}

RNA ISH was performed on PFA-fixed paraffin-embedded tissue sections using an RNAscope Chromogenic 2.0 Detection Kit (Advanced Cell Diagnostics [ACD], Inc.). A Ccr2 probe was custom designed by ACD, Inc. (\#436261-C2) and used according to 
the manufacturer's instructions. We confirmed that no signal was found with the probe using $\mathrm{Ccr}^{-/-}$tissues. RNA FISH for $\mathrm{Ccr} 2, \mathrm{Krt8}, \mathrm{Cd} 8 \mathrm{a}$, and Ifn-g was performed on fresh frozen tissue sections using an RNAscope Fluorescent Multiplex Assay Kit (ACD, Inc.) with the following probes (by ACD, Inc.): Ccr2: 436261-C2; Krt18: 424531-C1; Cd8a: 401681-C1; and Ifn-g: 311391C3. They were used according to the manufacturer's instructions. For Ccr2 RNA FISH, we confirmed that no signal was found with the probe using $\mathrm{CCr}^{-/-}$tissues.

\section{H\&E staining}

PFA-fixed paraffin-embedded tissue sections were deparaffinized and rehydrated following standard protocols, stained with Gill's Hematoxylin (REF6765008; Thermo Fisher Scientific) for $3 \mathrm{~min}$, washed in tap water, rinsed with Nu-Clear II (REF6769009; Thermo Fisher Scientific), and then rinsed again first with tap water and then with Bluing Reagent (REF 6769001; Thermo Fisher Scientific). Slides were then stained with eosin (HT110180; Sigma-Aldrich), dehydrated following standard protocols, air-dried, and mounted with Cytoseal 60 (\#831016; Thermo Fisher Scientific).

\section{Immunofluorescence staining}

To stain for cytokeratin 5 and cytokeratin 8, paraffin sections were deparaffinized and rehydrated, and antigen retrieval was performed by boiling slides in Tris EDTA buffer $(10 \mathrm{mM}$ Tris base and $1 \mathrm{mM}$ EDTA, pH 9.0) for $6 \mathrm{~min}$ in a pressure cooker. The slides were blocked with $1 \times$ blocking buffer (PBS containing $2.5 \% \mathrm{BSA}$ and $5 \%$ goat serum) and Fc receptor blocker (Innovex Biosciences) before incubating with anti-cytokeratin 5-Alexa Fluor 488 conjugated antibody (ab193894; 1:200 dilution; Abcam) and anti-Cytokeratin 8-Alexa Fluor 405 conjugated antibody (ab210139; 1:200 dilution; Abcam) overnight at $4^{\circ} \mathrm{C}$. Sections were counterstained with ToPro-3 (1:1,000 dilution; Life Technologies).

For all other stainings, frozen tissue sections were incubated with $1 \mathrm{x}$ blocking buffer ( $5 \%$ goat serum and $2.5 \%$ BSA in PBS) and $\mathrm{Fc}$ receptor blocker. Sections were incubated with rabbit anti-CD3 polyclonal antibody (1:500 dilution; Abcam), rat antiMHC class I monoclonal antibody (Clone ER-HR52, 1:100 dilution; Abcam), rat anti-PyMT antibody (Ab15085, 1:200 dilution; Abcam), rabbit anti-cleaved caspase-3 (Asp175; D3E9; \#9579; 1:200 dilution; Cell Signaling Technology), anti-CD8a-Alexa Fluor 488 (Clone 5.3-6.7), anti-CD11c-Alexa Fluor 488 (Clone N418), or anti-CD326 (EpCAM)-APC (Clone G8.8) in 0.5× blocking buffer overnight at $4^{\circ} \mathrm{C}$. Secondary antibodies (not used for primary antibodies conjugated to Alexa Fluor 488) anti-rabbit-Alexa568 or anti-rat-Alexa568 (1:150 dilution; Life Technologies) were used for detection, and sections were counterstained with DAPI (1:200 dilution; Life Technologies). Images were collected at 40× magnification using a Leica SP8 confocal or an AX10 microscope and an AxioCam HRc camera (Zeiss) and were analyzed using Volocity software (Version 6.3.0; PerkinElmer).

\section{Immunohistochemistry and terminal deoxynucleotidyl transferase dUTP nick end labeling (TUNEL) staining}

Sections were deparaffinized and rehydrated. For phosphoSTAT3 and Ki67 staining, antigen retrieval was performed by boiling slides in $10 \mathrm{mM}$ sodium citrate buffer (pH 6.0) for $6 \mathrm{~min}$ in a pressure cooker, while for phospho-STAT1 staining, antigen retrieval was done in Tris EDTA buffer (10 mM Tris base and $1 \mathrm{mM}$ EDTA, $\mathrm{pH}$ 9.0). The slides were blocked with $3 \%$ hydrogen peroxide, $1 \times$ blocking buffer (PBS containing $2.5 \%$ BSA and $5 \%$ goat serum), Fc receptor blocker, and finally avidin/biotin blocking buffer (SP-2001; Vector Laboratories). Slides were then incubated with primary antibodies overnight at $4^{\circ} \mathrm{C}$ in $0.5 \times$ blocking buffer: rabbit anti-Ki67/MK167 (1: 1,000 dilution; NB110-89717; Novus International), rabbit anti-phospho-STAT1 (1:200 dilution; Cell Signaling Technology), or rabbit anti-phospho-STAT3 (1:500 dilution; Cell Signaling Technology). After incubating with secondary biotinylated goat anti-rabbit IgG antibody (1:500 dilution; BA-1000; Vector Laboratories) for $1 \mathrm{~h}$ at room temperature, slides were incubated with avidin-conjugated horseradish peroxidase (PK-6100; Vector Laboratories) for $30 \mathrm{~min}$, and the signals were detected by a 3,3'diaminobenzidine substrate kit (SK-4100; Vector Laboratories). Lastly, sections were counterstained with hematoxylin. TUNEL staining was performed on deparaffinized sections to detect late-stage apoptotic cells using the ApopTag peroxidase in situ apoptosis detection kit (Millipore) according to the manufacturer's instructions. Images were scanned by an Aperio ScanScope CS System (Leica Biosystems), and positive nuclei were counted using Aperio eSlide Capture Devices software (Leica Biosystems).

\section{ImmunoSEQ}

Tumors from $\mathrm{Ccr}^{+/+}$and $\mathrm{Ccr}^{-/-}$transplants were isolated and immediately placed in liquid nitrogen for shipment. Amplification and sequencing were performed on the immunoSEQ platform (Adaptive Biotechnologies) using a multiplex PCR-based assay that exclusively targets rearranged TCR genes. Sequencing data were analyzed using immunoSEQ Analyzer software. Shannon's Entropy $(H)$, a measure of the richness and uniformity of the frequency of the TCR repertoire distribution, was defined as follows:

$$
H=-\sum_{i=1}^{N} P_{i} \log _{2} P_{i}
$$

where $N$ equals the number of unique clones and $P_{i}$ the frequency of clones. To account for variation in sequencing depth, entropy was normalized by its maximum value $\left(H_{\max }\right)$ :

$$
H_{N}=H / H_{\max } .
$$

Clonality is defined as $\mathrm{C}=1-H_{N}$ (Sherwood et al., 2013). Sequencing files are available from the immunoSEQ website through accession DOI 10.21417/MF2020JEM.

\section{Transcriptional profiling and bioinformatics analysis}

$\mathrm{CCr}^{+/+}$or $\mathrm{Ccr}^{-/-}$cancer cells were isolated from tumors and sorted as EpCAM ${ }^{+} \mathrm{CD} 45^{-} \mathrm{CD} 31^{-}$live cells (using 7-AAD Viability Staining Solution; Thermo Fisher Scientific) 4 wk after orthotopic transplantation into the mammary glands of wild-type C57BL/6 mice. Total cancer cell RNA was extracted using a 
TRIzol extraction protocol. cDNA libraries were prepared using the Ovation RNA-Seq System V2 (NuGEN Technologies) according to the manufacturer's protocol and sequenced using a NextSeq 500 instrument (Illumina) to obtain 388 million 76-bp single-end reads. Reads were mapped to the reference $\mathrm{mm} 9$ mouse genome using Spliced Transcripts Alignment to a Reference (Dobin et al., 2013) and were determined using HTSeq (Anders et al., 2015). Differential gene expression analysis was performed using DESeq2 (Love et al., 2014) with a false discovery rate cutoff of $5 \%$. Hierarchical clustering was performed by sample and gene using normalized and $\log _{2}$-transformed gene expression values of differentially expressed genes. All of the analyses described above were performed on the Bioinformatics Shared Resource Galaxy server at CSHL. Gene set enrichment analysis (Subramanian et al., 2005) was performed on a preranked gene list sorted by $\log _{2}$ FoldChange value against v5.1 Hallmark gene sets using default parameters. GO term enrichment analysis was performed using GOrilla PANTHER (Eden et al., 2009). The RNA-seq data have been deposited in the Sequence Read Archive with accession no. PRJNA605445 (https:// www.ncbi.nlm.nih.gov/Traces/study/?acc=PRJNA605445).

\section{BMDC isolation, culture, and activation}

BMDCs were isolated and cultured as previously described (Inaba et al., 1992). Briefly, bone marrow was obtained from female C57BL/ 6 mice by flushing the femur and tibia with $2 \mathrm{ml}$ of HBSS using a 1-ml insulin syringe with a $29 \mathrm{G} \times 1 / 2$ needle. The cells were washed with HBSS twice by centrifugation at $250 \times g$ for $8 \mathrm{~min}$ and then suspended in BMDC culture medium (RPMI1640 medium [Thermo Fisher Scientific] containing 10\% FBS, $20 \mathrm{ng} / \mathrm{ml}$ recombinant mouse GM-CSF [BioLegend], $50 \mathrm{U} / \mathrm{ml}$ penicillin, and $50 \mu \mathrm{g} / \mathrm{ml}$ streptomycin). The cells were then plated in $10-\mathrm{cm}$ culture plates $\left(2 \times 10^{6}\right.$ cells per Petri dish $)$ and kept at $37^{\circ} \mathrm{C}$ in a $5 \% \mathrm{CO}_{2}$ incubator for $3 \mathrm{~d}$, and then split at day 4 into two plates. For activation of BMDCs with cancer cellconditioned medium, the nonattached BMDCs were harvested at day 6 by gently pipetting the cultures with medium. This BMDC population was then rinsed three times in HBSS and suspended in (1) culture medium, (2) conditioned medium from MMTV-PyMT;Ccr2 ${ }^{-/-}$or MMTV-PyMT;C $C r 2^{+/+}$cancer cells, or (3) conditioned medium from MMTV-PyMT;Ccr2 ${ }^{+/+}$cancer cells cultured either with or without CCR2 antagonist (10 $\mu \mathrm{M}$; RS504393; Sigma-Aldrich). After incubation with conditioned medium for $24 \mathrm{~h}$, nonadherent BMDCs were harvested for flow cytometry.

\section{Chromium release assay}

Cytotoxic $\mathrm{CD}^{+} \mathrm{T}$ cells were isolated from spleens of OT-I transgenic mice by magnetic labeling and separation (Miltenyi Biotec). Briefly, the spleen was forced through a $100-\mu \mathrm{m}$ cell strainer, and flow-through cells were collected. After red blood cells were lysed, the splenocytes were washed and incubated with CD8 $\mathrm{a}^{+} \mathrm{T}$ Cell Biotin-Antibody Cocktail, mouse (Miltenyi Biotec) at $4^{\circ} \mathrm{C}$ for $5 \mathrm{~min}$, followed by incubating with anti-biotin microbeads (Miltenyi Biotec) at $4^{\circ} \mathrm{C}$ for $10 \mathrm{~min}$. The cell suspension was applied to an LS column (Miltenyi Biotec) in a magnetic field, and the flow-through (negatively selected) $\mathrm{CD} 8^{+}$
$\mathrm{T}$ cells were collected. The isolated $\mathrm{CD} 8^{+} \mathrm{T}$ cells were cultured on plates coated with anti-mouse-CD3 (BioLegend) in RPMI-1640 containing $10 \%$ FBS, $50 \mu \mathrm{M}$ of $\beta$-mercaptoethanol, $20 \mathrm{ng} / \mathrm{ml}$ mouse IL-2, $2 \mathrm{ng} / \mathrm{ml}$ mouse IL-7, and $1 \%$ penicillin/streptomycin for 6-9 d. Primary cancer cells were isolated as described above from MMTV-PyMT-chOVA;Ccr2 ${ }^{+/+}$or MMTV-PyMT-chOVA; $\mathrm{CCr}^{-/-}$mice and cultured overnight with or without CCR2 antagonist (10 $\mu \mathrm{M}$; RS504393) and OVA peptides $(1 \mu \mathrm{g} / \mathrm{ml})$ in DMEM/F12 medium with 10\% FBS. The E0771 cancer cell line was infected with lentivirus expressing luciferase and OVA SIINFEKL peptide fused to the C-terminus of enhanced GFP. Transduced cells were sorted by flow cytometry for enhanced GFP-positive cells. For chromium $\left({ }^{51} \mathrm{Cr}\right)$ release assay, cancer cells (1,000 per well) were incubated with $50 \mu \mathrm{l}$ of ${ }^{51} \mathrm{Cr}$ solution (activity $1 \mathrm{mCi} / \mathrm{ml}$; PerkinElmer) plus $50 \mu \mathrm{l}$ of RPMI medium with $10 \% \mathrm{FBS}$ for $2 \mathrm{~h}$ at $37^{\circ} \mathrm{C}$. After the cells were rinsed three times with RPMI plus $10 \%$ FBS, $50 \mu \mathrm{l}$ of cancer cells $(1,000)$ were plated into each well of a 96-well V-bottom plate, followed by the addition of $50 \mu \mathrm{l}$ of CD8 ${ }^{+} \mathrm{T}$ cells at a ratio of 10:1. After $4 \mathrm{~h}$ of incubation at $37^{\circ} \mathrm{C}, 50 \mu \mathrm{l}$ of supernatant from each well was transferred to miniature vials, and radioactivity was determined by a Beckman scintillation counter (PerkinElmer). The percentage of specific lysis was calculated using the standard formula [(experimental - spontaneous release)/(total - spontaneous release) $\times$ 100] and expressed as the mean of triplicate samples.

\section{Western blot}

Snap-frozen tumor samples were homogenized in radio immunoprecipitation assay buffer with cOmplete Protease Inhibitor Cocktail Tablets (Roche) and phosphatase inhibitor cocktail (Thermo Fisher Scientific), and lysis was performed on ice for $30 \mathrm{~min}$. Cell lysates were centrifuged for $15 \mathrm{~min}$ at $12,000 \times \mathrm{g}$ at $4^{\circ} \mathrm{C}$. After centrifugation, the supernatant was mixed with $4 \times$ loading buffer plus $2.5 \%$ of $\beta$-mercaptoethanol and loaded on $8 \%$ SDS/PAGE gels. Proteins with similar molecular weight were detected using blots from separate gels loaded with an equal amount of samples. Protein bands were transferred to polyvinylidene difluoride membranes (Bio-Rad) at $90 \mathrm{~V}$ for $2 \mathrm{~h}$ in a Bio-Rad Mini Trans-Blot system. The membrane was incubated sequentially with different primary antibodies: anti-p65, antip-p65, anti-p-STAT1, anti-p-STAT3, and anti-STAT3 (all from Cell Signaling Technology) and anti-STAT1 and anti- $\beta$-Actin (Santa Cruz Biotechnology). Secondary antibodies were from LI-COR. Protein detection was performed using the Odyssey imaging system (LI-COR).

\section{Whole-mount carmine staining of mammary glands}

Mammary glands were isolated and spread out on glass slides. Then, the mammary glands were fixed in Carnoy's fixative $(60 \%$ ethanol, $30 \%$ chloroform, and $10 \%$ glacial acetic acid) for $2-4 \mathrm{~h}$ at room temperature, followed by 15 -min washes first in $70 \%$ and then in 50\% ethanol, with a final rinse in double-distilled water. The glands were then stained with carmine red stain ( $2.5 \mathrm{~g}$ of aluminum potassium sulfate, $1 \mathrm{~g}$ of carmine, and $\mathrm{d}_{2} \mathrm{O}$ to a final volume of $500 \mathrm{ml}$, and boiled for $25 \mathrm{~min}$ ) for $16 \mathrm{~h}$ or until the fat pad was a uniform pink color. After staining, the mammary glands were de-stained in $1 \%$ solution of $1 \mathrm{~N} \mathrm{HCl}$ in $70 \%$ ethanol. 
De-stained glands were rinsed twice for $15 \mathrm{~min}$ in $70 \%$ ethanol followed by 15 -min washes first in $90 \%$ and then in $100 \%$ ethanol. The mammary glands were then placed in xylene for $2 \mathrm{~h}$ for clearing and were mounted.

\section{Statistical analysis}

All statistical analyses were performed using GraphPad Prism Version 6 or newer software. Data were analyzed using KaplanMeier survival analysis, Student's $t$ tests, ANOVA, $\chi^{2}$ test, and log-rank (Mantel-Cox) test, as indicated in the figure legends, with an $\alpha$ of 0.05 . For tumor volume analysis, oneway ANOVA followed by Sidak's multiple comparisons test; Welch's ANOVA followed by Dunnett's T3 multiple comparisons test; or Student's $t$ tests were performed as indicated in the legends. The number of sampled units, $n$, is indicated in the figure legends.

\section{Online supplemental material}

Fig. S1 (related to Fig. 1) shows CCR2 expression in spontaneous MMTV-PyMT tumors and lungs. Fig. S2 shows the flow cytometry gating strategy for immune cells. Fig. S3 (related to Figs. 4 and 5) shows $\mathrm{T}$ cell infiltration and depletion in tumors derived from $\mathrm{Ccr}^{+/+}$or $\mathrm{Ccr}^{-/-}$cancer cells. Fig. S4 (related to Figs. 8 and 9) shows the activation of $\mathrm{T}$ cells and the infiltration of myeloid cell in tumors derived from $\mathrm{Ccr} 2^{+/+}$or $\mathrm{Ccr}^{-/-}$cancer cells. Fig. S5 (related to Fig. 10) shows cytokine analysis in tumor lysate and conditioned medium.

\section{Acknowledgments}

We thank Laura Maiorino for drawing the included illustrations.

This work was supported by funds from the CSHL Cancer Center (P30-CA045508) and the Department of Defense (W81XWH-14-1-0078) to M. Egeblad; from the Charles and Marie Robertson Foundation to X.-Y. He; from the Lustgarten Foundation, the National Cancer Institute, and the Cedar Hill Foundation to D.T. Fearon; from the Rita Allen Foundation and the V Foundation for Cancer Research to C.O. dos Santos; and a Starr Centennial Scholarship from the Watson School of Biological Sciences to E. Bružas. R. Yan is a George A. and Marjorie H. Anderson Fellow. M. Egeblad, C.O. dos Santos, and L. Van Aelst were supported by a grant from the Simons Foundation to CSHL. Support was also provided by the State of New York (contract no. C150158), and the opinions, results, findings and/ or interpretations of data contained therein do not necessarily represent the opinions, interpretations, or policy of the State.

Author contributions: M.R. Fein, X.-Y. He, and M. Egeblad designed the experiments. M.R. Fein and X.-Y. He performed the in vitro experiments; M.R. Fein, C.O. dos Santos, and E. Bružas isolated RNA from cancer cells and performed the RNA-seq analysis. M.R. Fein and X.-Y. He performed the animal experiments; A.S. Almeida, M.R. Fein, A. Pommier, and X.-Y. He performed flow cytometry; J.E. Wilkinson analyzed the histological sections; and M.R. Fein, X.-Y. He, and A. Eberhardt performed immunohistochemistry and ISHs. X.-Y. He, A. Pommier, R. Yan, and M.R. Fein designed and performed the chromium release experiments; and A. Eberhardt, M.R. Fein, and X.-Y. He performed
qPCR. L. Van Aelst and D.T. Fearon provided experimental advice. M.R. Fein, X.-Y. He, and M. Egeblad wrote the manuscript.

Disclosures: M. Egeblad reported "other" from Agios Pharmaceutical, personal fees from MPM Gilead, and personal fees from CytomX outside the submitted work. No other disclosures were reported.

Submitted: 13 August 2018

Revised: 27 December 2019

Accepted: 26 May 2020

\section{References}

Ahn, R., V. Sabourin, A.M. Bolt, S. Hébert, S. Totten, N. De Jay, M.C. Festa, Y.K. Young, Y.K. Im, T. Pawson, et al. 2017. The Shcl adaptor simultaneously balances Statl and Stat3 activity to promote breast cancer immune suppression. Nat. Commun. 8:14638. https://doi.org/10.1038/ ncomms 14638

Anders, S., P.T. Pyl, and W. Huber. 2015. HTSeq--a Python framework to work with high-throughput sequencing data. Bioinformatics. 31:166-169. https://doi.org/10.1093/bioinformatics/btu638

Avalle, L., S. Pensa, G. Regis, F. Novelli, and V. Poli. 2012. STAT1 and STAT3 in tumorigenesis: A matter of balance. JAK-STAT. 1:65-72. https://doi.org/ $10.4161 / j k s t .20045$

Bayne, L.J., G.L. Beatty, N. Jhala, C.E. Clark, A.D. Rhim, B.Z. Stanger, and R.H. Vonderheide. 2012. Tumor-derived granulocyte-macrophage colonystimulating factor regulates myeloid inflammation and $\mathrm{T}$ cell immunity in pancreatic cancer. Cancer Cell. 21:822-835. https://doi.org/10 .1016/j.ccr.2012.04.025

Bonapace, L., M.M. Coissieux, J. Wyckoff, K.D. Mertz, Z. Varga, T. Junt, and M. Bentires-Alj. 2014. Cessation of CCL2 inhibition accelerates breast cancer metastasis by promoting angiogenesis. Nature. 515:130-133. https://doi.org/10.1038/nature13862

Boring, L., J. Gosling, S.W. Chensue, S.L. Kunkel, R.V. Farese, Jr., H.E. Broxmeyer, and I.F. Charo. 1997. Impaired monocyte migration and reduced type 1 (Th1) cytokine responses in C-C chemokine receptor 2 knockout mice. J. Clin. Invest. 100:2552-2561. https://doi.org/10 $.1172 /$ JCI119798

Broz, M.L., M. Binnewies, B. Boldajipour, A.E. Nelson, J.L. Pollack, D.J. Erle, A. Barczak, M.D. Rosenblum, A. Daud, D.L. Barber, et al. 2014. Dissecting the tumor myeloid compartment reveals rare activating antigenpresenting cells critical for T cell immunity. Cancer Cell. 26:638-652. https://doi.org/10.1016/j.ccell.2014.09.007

Chen, W., Q. Gao, S. Han, F. Pan, and W. Fan. 2015. The CCL2/CCR2 axis enhances IL-6-induced epithelial-mesenchymal transition by cooperatively activating STAT3-Twist signaling. Tumour Biol. 36:973-981. https://doi.org/10.1007/s13277-014-2717-z

Chen, J., C.C. Jiang, L. Jin, and X.D. Zhang. 2016a. Regulation of PD-L1: a novel role of pro-survival signalling in cancer. Ann. Oncol. 27:409-416. https:// doi.org/10.1093/annonc/mdv615

Chen, X., Y. Wang, D. Nelson, S. Tian, E. Mulvey, B. Patel, I. Conti, J. Jaen, and B.J. Rollins. 2016b. CCL2/CCR2 Regulates the Tumor Microenvironment in HER-2/neu-Driven Mammary Carcinomas in Mice. PLoS One. 11:e0165595. https://doi.org/10.1371/journal.pone .0165595

de Mingo Pulido, Á., A. Gardner, S. Hiebler, H. Soliman, H.S. Rugo, M.F. Krummel, L.M. Coussens, and B. Ruffell. 2018. TIM-3 Regulates CD103 ${ }^{+}$ Dendritic Cell Function and Response to Chemotherapy in Breast Cancer. Cancer Cell. 33:60-74.e6. https://doi.org/10.1016/j.ccell.2017.11 019

Deshmane, S.L., S. Kremlev, S. Amini, and B.E. Sawaya. 2009. Monocyte chemoattractant protein-1 (MCP-1): an overview. J. Interferon Cytokine Res. 29:313-326. https://doi.org/10.1089/jir.2008.0027

Dobin, A., C.A. Davis, F. Schlesinger, J. Drenkow, C. Zaleski, S. Jha, P. Batut, M. Chaisson, and T.R. Gingeras. 2013. STAR: ultrafast universal RNA-seq aligner. Bioinformatics. 29:15-21. https://doi.org/10 $.1093 /$ bioinformatics/bts635

Dunn, G.P., A.T. Bruce, H. Ikeda, L.J. Old, and R.D. Schreiber. 2002. Cancer immunoediting: from immunosurveillance to tumor escape. Nat. Immunol. 3:991-998. https://doi.org/10.1038/nil102-991 
Dunn, G.P., L.J. Old, and R.D. Schreiber. 2004. The three Es of cancer immunoediting. Annu. Rev. Immunol. 22:329-360. https://doi.org/10.1146/ annurev.immunol.22.012703.104803

Eden, E., R. Navon, I. Steinfeld, D. Lipson, and Z. Yakhini. 2009. GOrilla: a tool for discovery and visualization of enriched GO terms in ranked gene lists. BMC Bioinformatics. 10:48. https://doi.org/10.1186/1471-2105-10-48

Engelhardt, J.J., B. Boldajipour, P. Beemiller, P. Pandurangi, C. Sorensen, Z. Werb, M. Egeblad, and M.F. Krummel. 2012. Marginating dendritic cells of the tumor microenvironment cross-present tumor antigens and stably engage tumor-specific T cells. Cancer Cell. 21:402-417. https://doi .org/10.1016/j.ccr.2012.01.008

Fang, W.B., I. Jokar, A. Zou, D. Lambert, P. Dendukuri, and N. Cheng. 2012. CCL2/CCR2 chemokine signaling coordinates survival and motility of breast cancer cells through Smad3 protein- and p42/44 mitogenactivated protein kinase (MAPK)-dependent mechanisms. J. Biol. Chem. 287:36593-36608. https://doi.org/10.1074/jbc.M112.365999

Flores-Toro, J.A., D. Luo, A. Gopinath, M.R. Sarkisian, J.J. Campbell, I.F. Charo, R. Singh, T.J. Schall, M. Datta, R.K. Jain, et al. 2020. CCR2 inhibition reduces tumor myeloid cells and unmasks a checkpoint inhibitor effect to slow progression of resistant murine gliomas. Proc. Natl. Acad. Sci. USA. 117:1129-1138. https://doi.org/10.1073/pnas .1910856117

Freeman, G.J., A.J. Long, Y. Iwai, K. Bourque, T. Chernova, H. Nishimura, L.J. Fitz, N. Malenkovich, T. Okazaki, M.C. Byrne, et al. 2000. Engagement of the PD-1 immunoinhibitory receptor by a novel B7 family member leads to negative regulation of lymphocyte activation. J. Exp. Med. 192: 1027-1034. https://doi.org/10.1084/jem.192.7.1027

Garrido, F., I. Romero, N. Aptsiauri, and A.M. Garcia-Lora. 2016. Generation of MHC class I diversity in primary tumors and selection of the malignant phenotype. Int. J. Cancer. 138:271-280. https://doi.org/10.1002/ ijc. 29375

Greter, M., J. Helft, A. Chow, D. Hashimoto, A. Mortha, J. Agudo-Cantero, M. Bogunovic, E.L. Gautier, J. Miller, M. Leboeuf, et al. 2012. GM-CSF controls nonlymphoid tissue dendritic cell homeostasis but is dispensable for the differentiation of inflammatory dendritic cells. Immunity. 36:1031-1046. https://doi.org/10.1016/j.immuni.2012.03.027

Guy, C.T., R.D. Cardiff, and W.J. Muller. 1992. Induction of mammary tumors by expression of polyomavirus middle $\mathrm{T}$ oncogene: a transgenic mouse model for metastatic disease. Mol. Cell. Biol. 12:954-961. https://doi.org/ 10.1128/MCB.12.3.954

Hildner, K., B.T. Edelson, W.E. Purtha, M. Diamond, H. Matsushita, M. Kohyama, B. Calderon, B.U. Schraml, E.R. Unanue, M.S. Diamond, et al. 2008. Batf3 deficiency reveals a critical role for CD8alpha+ dendritic cells in cytotoxic T cell immunity. Science. 322:1097-1100. https://doi .org/10.1126/science.1164206

Hu, Q., M. Myers, W. Fang, M. Yao, G. Brummer, J. Hawj, C. Smart, C. Berkland, and N. Cheng. 2019. Role of ALDH1A1 and HTRA2 expression in CCL2/CCR2-mediated breast cancer cell growth and invasion. Biol. Open. 8. bio040873. https://doi.org/10.1242/bio.040873

Igney, F.H., and P.H. Krammer. 2002. Immune escape of tumors: apoptosis resistance and tumor counterattack. J. Leukoc. Biol. 71:907-920.

Inaba, K., M. Inaba, N. Romani, H. Aya, M. Deguchi, S. Ikehara, S. Muramatsu, and R.M. Steinman. 1992. Generation of large numbers of dendritic cells from mouse bone marrow cultures supplemented with granulocyte/macrophage colony-stimulating factor. J. Exp. Med. 176: 1693-1702. https://doi.org/10.1084/jem.176.6.1693

Izumi, K., L.Y. Fang, A. Mizokami, M. Namiki, L. Li, W.J. Lin, and C. Chang. 2013. Targeting the androgen receptor with siRNA promotes prostate cancer metastasis through enhanced macrophage recruitment via CCL2/CCR2-induced STAT3 activation. EMBO Mol. Med. 5:1383-1401. https://doi.org/10.1002/emmm.201202367

Jones, L.M., M.L. Broz, J.J. Ranger, J. Ozcelik, R. Ahn, D. Zuo, J. Ursini-Siegel, M.T. Hallett, M. Krummel, and W.J. Muller. 2016. STAT3 Establishes an Immunosuppressive Microenvironment during the Early Stages of Breast Carcinogenesis to Promote Tumor Growth and Metastasis. Cancer Res. 76: 1416-1428. https://doi.org/10.1158/0008-5472.CAN-15-2770

Labovsky, V., L.M. Martinez, K.M. Davies, M. de Luján Calcagno, H. GarcíaRivello, A. Wernicke, L. Feldman, A. Matas, M.B. Giorello, F.R. Borzone, et al. 2017. Prognostic significance of TRAIL-R3 and CCR-2 expression in tumor epithelial cells of patients with early breast cancer. BMC Cancer. 17:280. https://doi.org/10.1186/s12885-017-3259-8

Lebrecht, A., L. Hefler, C. Tempfer, and H. Koelbl. 2001. Serum cytokine concentrations in patients with cervical cancer: interleukin-4, interferon-gamma, and monocyte chemoattractant protein-1. Gynecol. Oncol. 83:170-171. https://doi.org/10.1006/gyno.2001.6361
Lebrecht, A., C. Grimm, T. Lantzsch, E. Ludwig, L. Hefler, E. Ulbrich, and H. Koelbl. 2004. Monocyte chemoattractant protein-1 serum levels in patients with breast cancer. Tumour Biol. 25:14-17. https://doi.org/10.1159/ 000077718

Li, M., D.A. Knight, L. A Snyder, M.J. Smyth, and T.J. Stewart. 2013. A role for CCL2 in both tumor progression and immunosurveillance. OncoImmunology. 2. e25474. https://doi.org/10.4161/onci.25474

Lim, S.Y., A.E. Yuzhalin, A.N. Gordon-Weeks, and R.J. Muschel. 2016. Targeting the CCL2-CCR2 signaling axis in cancer metastasis. Oncotarget. 7: 28697-28710. https://doi.org/10.18632/oncotarget.7376

Lin, E.Y., J.G. Jones, P. Li, L. Zhu, K.D. Whitney, W.J. Muller, and J.W. Pollard. 2003. Progression to malignancy in the polyoma middle T oncoprotein mouse breast cancer model provides a reliable model for human diseases. Am. J. Pathol. 163:2113-2126. https://doi.org/10.1016/S0002 $-9440(10) 63568-7$

Love, M.I., W. Huber, and S. Anders. 2014. Moderated estimation of fold change and dispersion for RNA-seq data with DESeq2. Genome Biol. 15: 550. https://doi.org/10.1186/s13059-014-0550-8

Lu, Y., Z. Cai, D.L. Galson, G. Xiao, Y. Liu, D.E. George, M.F. Melhem, Z. Yao, and J. Zhang. 2006. Monocyte chemotactic protein-1 (MCP-1) acts as a paracrine and autocrine factor for prostate cancer growth and invasion. Prostate. 66:1311-1318. https://doi.org/10.1002/pros.20464

Mayer, C.T., P. Ghorbani, A. Nandan, M. Dudek, C. Arnold-Schrauf, C. Hesse, L. Berod, P. Stüve, F. Puttur, M. Merad, et al. 2014. Selective and efficient generation of functional Batf3-dependent CD103+ dendritic cells from mouse bone marrow. Blood. 124:3081-3091. https://doi.org/10 .1182/blood-2013-12-545772

Mehta, H.M., M. Malandra, and S.J. Corey. 2015. G-CSF and GM-CSF in Neutropenia. J. Immunol. 195:1341-1349. https://doi.org/10.4049/ jimmunol.1500861

Meyer, M.A., J.M. Baer, B.L. Knolhoff, T.M. Nywening, R.Z. Panni, X. Su, K.N. Weilbaecher, W.G. Hawkins, C. Ma, R.C. Fields, et al. 2018. Breast and pancreatic cancer interrupt IRF8-dependent dendritic cell development to overcome immune surveillance. Nat. Commun. 9:1250. https://doi .org/10.1038/s41467-018-03600-6

Mitchell, L.A., R.J. Hansen, A.J. Beaupre, D.L. Gustafson, and S.W. Dow. 2013. Optimized dosing of a CCR2 antagonist for amplification of vaccine immunity. Int. Immunopharmacol. 15:357-363. https://doi.org/10.1016/j intimp.2012.11.016

Müller, A., B. Homey, H. Soto, N. Ge, D. Catron, M.E. Buchanan, T. McClanahan, E. Murphy, W. Yuan, S.N. Wagner, et al. 2001. Involvement of chemokine receptors in breast cancer metastasis. Nature. 410:50-56. https://doi.org/10.1038/35065016

Nakasone, E.S., H.A. Askautrud, T. Kees, J.H. Park, V. Plaks, A.J. Ewald, M. Fein, M.G. Rasch, Y.X. Tan, J. Qiu, et al. 2012. Imaging tumor-stroma interactions during chemotherapy reveals contributions of the microenvironment to resistance. Cancer Cell. 21:488-503. https://doi.org/10 .1016/j.ccr.2012.02.017

Nielsen, B.S., L.R. Lund, I.J. Christensen, M. Johnsen, P.A. Usher, L. WulfAndersen, T.L. Frandsen, K. Danø, and H.J. Gundersen. 2001. A precise and efficient stereological method for determining murine lung metastasis volumes. Am. J. Pathol. 158:1997-2003. https://doi.org/10.1016/ S0002-9440(10)64671-8

Nywening, T.M., A. Wang-Gillam, D.E. Sanford, B.A. Belt, R.Z. Panni, B.M. Cusworth, A.T. Toriola, R.K. Nieman, L.A. Worley, M. Yano, et al. 2016. Targeting tumour-associated macrophages with CCR2 inhibition in combination with FOLFIRINOX in patients with borderline resectable and locally advanced pancreatic cancer: a single-centre, open-label, dose-finding, non-randomised, phase $1 \mathrm{~b}$ trial. Lancet Oncol. 17:651-662. https://doi.org/10.1016/S1470-2045(16)00078-4

Pylayeva-Gupta, Y., K.E. Lee, C.H. Hajdu, G. Miller, and D. Bar-Sagi. 2012. Oncogenic Kras-induced GM-CSF production promotes the development of pancreatic neoplasia. Cancer Cell. 21:836-847. https://doi.org/10 .1016/j.ccr.2012.04.024

Qian, B., Y. Deng, J.H. Im, R.J. Muschel, Y. Zou, J. Li, R.A. Lang, and J.W. Pollard. 2009. A distinct macrophage population mediates metastatic breast cancer cell extravasation, establishment and growth. PLoS One. 4. e6562. https://doi.org/10.1371/journal.pone.0006562

Qian, B.Z., J. Li, H. Zhang, T. Kitamura, J. Zhang, L.R. Campion, E.A. Kaiser, L.A. Snyder, and J.W. Pollard. 2011. CCL2 recruits inflammatory monocytes to facilitate breast-tumour metastasis. Nature. 475:222-225. https://doi.org/10.1038/nature10138

Roberts, E.W., M.L. Broz, M. Binnewies, M.B. Headley, A.E. Nelson, D.M. Wolf, T. Kaisho, D. Bogunovic, N. Bhardwaj, and M.F. Krummel. 2016. Critical Role for CD103(+)/CD141(+) Dendritic Cells Bearing CCR7 for 
Tumor Antigen Trafficking and Priming of T Cell Immunity in Melanoma. Cancer Cell. 30:324-336. https://doi.org/10.1016/j.ccell.2016.06.003

Rodríguez-Frade, J.M., A.J. Vila-Coro, A.M. de Ana, J.P. Albar, C. Martínez-A, and M. Mellado. 1999. The chemokine monocyte chemoattractant protein-1 induces functional responses through dimerization of its receptor CCR2. Proc. Natl. Acad. Sci. USA. 96:3628-3633. https://doi.org/10 $.1073 /$ pnas.96.7.3628

Ruffell, B., D. Chang-Strachan, V. Chan, A. Rosenbusch, C.M. Ho, N. Pryer, D. Daniel, E.S. Hwang, H.S. Rugo, and L.M. Coussens. 2014. Macrophage IL-10 blocks CD8+ T cell-dependent responses to chemotherapy by suppressing IL-12 expression in intratumoral dendritic cells. Cancer Cell. 26:623-637. https://doi.org/10.1016/j.ccell.2014.09.006

Sherwood, A.M., R.O. Emerson, D. Scherer, N. Habermann, K. Buck, J. Staffa, C. Desmarais, N. Halama, D. Jaeger, P. Schirmacher, et al. 2013. Tumorinfiltrating lymphocytes in colorectal tumors display a diversity of $\mathrm{T}$ cell receptor sequences that differ from the $\mathrm{T}$ cells in adjacent mucosal tissue. Cancer Immunol. Immunother. 62:1453-1461. https://doi.org/10 $.1007 / \mathrm{s} 00262-013-1446-2$

Soria, G., and A. Ben-Baruch. 2008. The inflammatory chemokines CCL2 and CCL5 in breast cancer. Cancer Lett. 267:271-285. https://doi.org/10.1016/ j.canlet.2008.03.018
Spranger, S., D. Dai, B. Horton, and T.F. Gajewski. 2017. Tumor-Residing Batf3 Dendritic Cells Are Required for Effector T Cell Trafficking and Adoptive T Cell Therapy. Cancer Cell. 31:711-723.e4. https://doi.org/10 $.1016 /$ j.ccell.2017.04.003

Subramanian, A., P. Tamayo, V.K. Mootha, S. Mukherjee, B.L. Ebert, M.A. Gillette, A. Paulovich, S.L. Pomeroy, T.R. Golub, E.S. Lander, et al. 2005. Gene set enrichment analysis: a knowledge-based approach for interpreting genome-wide expression profiles. Proc. Natl. Acad. Sci. USA. 102:15545-15550. https://doi.org/10.1073/pnas .0506580102

Winograd, R., K.T. Byrne, R.A. Evans, P.M. Odorizzi, A.R. Meyer, D.L. Bajor, C. Clendenin, B.Z. Stanger, E.E. Furth, E.J. Wherry, et al. 2015. Induction of T-cell Immunity Overcomes Complete Resistance to PD 1 and CTLA-4 Blockade and Improves Survival in Pancreatic Carcinoma. Cancer Immunol. Res. 3:399-411. https://doi.org/10.1158/2326 -6066.CIR-14-0215

Wolf, M.J., A. Hoos, J. Bauer, S. Boettcher, M. Knust, A. Weber, N. Simonavicius, C. Schneider, M. Lang, M. Stürzl, et al. 2012. Endothelial CCR2 signaling induced by colon carcinoma cells enables extravasation via the JAK2-Stat5 and p38MAPK pathway. Cancer Cell. 22:91-105. https:// doi.org/10.1016/j.ccr.2012.05.023 


\section{Supplemental material}




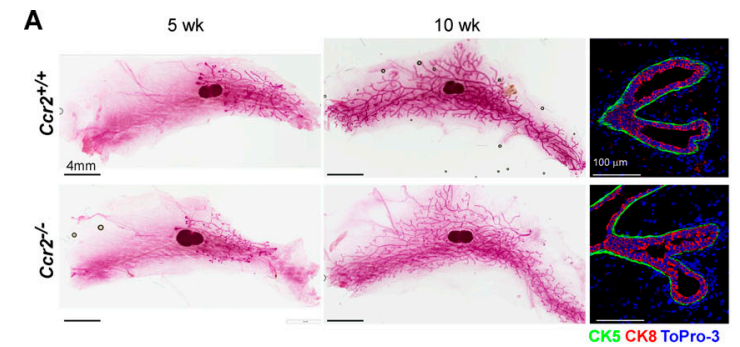

C

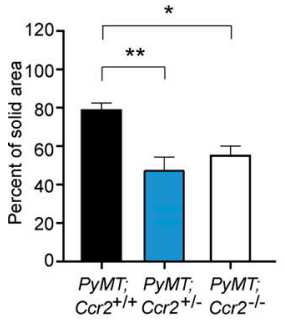

D

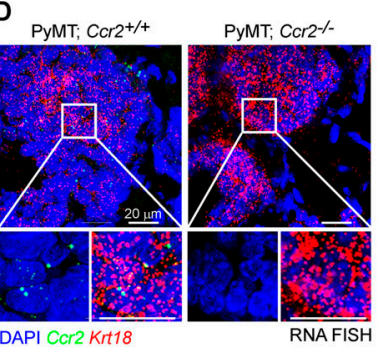

B

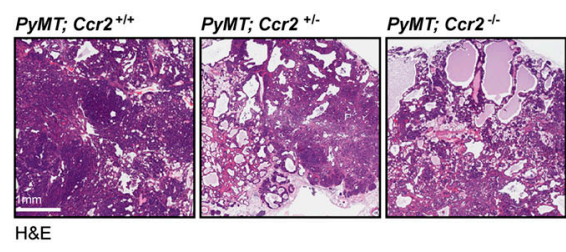

E

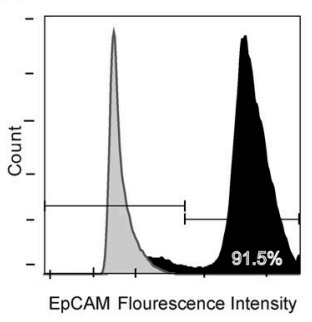

F

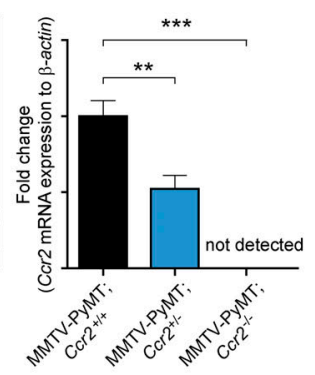

G
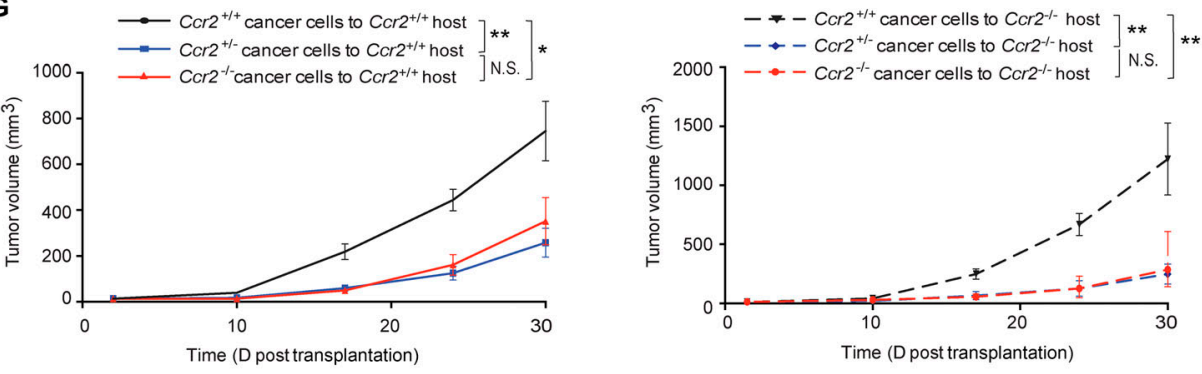

H

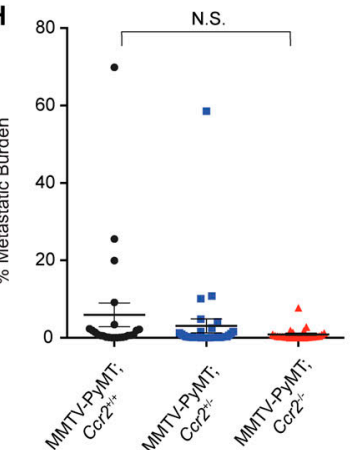

I

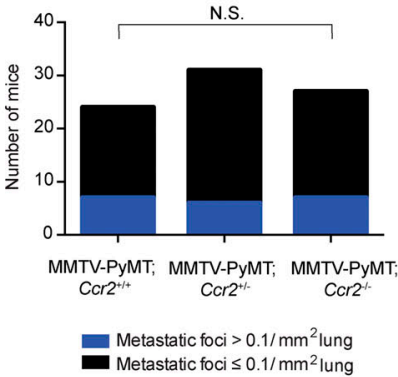

J

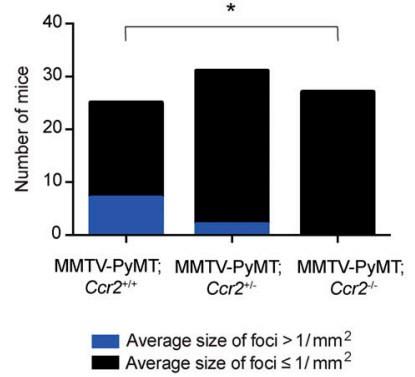

Figure S1. CCR2 expression in spontaneous MMTV-PyMT tumors and lungs. (A) Mammary ductal epithelial branching and invasion are similar in Ccr2 ${ }^{+/+}$ and $\mathrm{Crr}^{-/-}$mice, as indicated by carmine red staining of inguinal mammary glands at indicated age (left; scale bar $=4 \mathrm{~mm}$ ) and immunofluorescence staining of basal and luminal cell markers (right; cytokeratin [CK] 5 and CK8, respectively; scale bar = $100 \mu \mathrm{m}$ ). (B) Representative photomicrographs of H\&E-stained tumors from MMTV-PyMT;C Cr2 ${ }^{+/+}$, MMTV-PyMT; $C \mathrm{Cr} 2^{+/-}$, and MMTV-PyMT; $C \mathrm{Cr}^{-/-}$mice (scale bar $\left.=1 \mathrm{~mm}\right)$. (C) Histology score of solid area of primary tumors from MMTV-PyMT;CCr2 ${ }^{+/+}$, MMTV-PyMT;CCr2 $2^{+/-}$, and MMTV-PyMT;Ccr2 $2^{-/-}$mice (one-way ANOVA; $n=8$ in MMTV-PyMT;Ccr2 $2^{+/+}, n=11$ in MMTV-PyMT; $\mathrm{Ccr2}^{+/-}$, and $n=12$ in MMTV-PyMT;Ccr2 ${ }^{-/-}$). (D) Left: Representative RNA FISH on MMTV-PyMT;Ccr2 ${ }^{+/+}$tumors showing that Ccr2 mRNA (green) is expressed by Krt18-positive (red) cancer cells. Right: No Ccr2 expression is detected in MMTV-PyMT;Ccr2-/- tumors. Scale bar $=20 \mu \mathrm{m}$. (E) Purity of cancer cells is $>90 \%$ after cell isolation, as determined by flow cytometry for EpCAM (black; a marker expressed on epithelial-derived MMTV-PyMT cells) compared with background (gray). Representative of three separate isolations. (F) mRNA was collected from MMTV-PyMT;Ccr2 $2^{+/+}$, MMTV-PyMT;CCr2 $2^{+/-}$, and MMTV-PyMT; $C c r 2^{-/-}$ tumor cells, and qPCR was performed for $\mathrm{Ccr} 2$ and normalized to $\beta$-actin expression (one-way ANOVA; $n=3$ ). (G) Tumors from $\mathrm{Ccr} 2^{+/-}$cancer cells phenocopy those from $\mathrm{Ccr}_{2}^{-/-}$cancer cells, regardless of whether the host is $\mathrm{Ccr}^{+/+}$or $\mathrm{Ccr}^{-/-}$. Tumor burden was determined by weekly caliper measurements (one-way ANOVA followed by Sidak's multiple comparisons test at the end time point; $n=8$ for all conditions). (H) Metastatic burden is unchanged in MMTV-PyMT; $\mathrm{CCr}^{+/+}, \mathrm{MMTV}^{-\mathrm{PyMT}} ; \mathrm{CCr}^{+/-}$, and MMTV-PyMT; $\mathrm{Crr}^{-/-}$mice, as determined by quantification from H\&E-stained lung sections, indicated as percentage of the area of the lung tissues (one-way ANOVA; $n=24$ MMTV-PyMT;C Cr2 ${ }^{+/+}, 33$ MMTV-PyMT;C Cr2 $2^{+/-}$, and 27 MMTV-PyMT;C Cr2 ${ }^{-/-}$mice). (I) The number of metastatic foci is unchanged in MMTV-PyMT; $C \mathrm{Cr} 2^{+/+}$, MMTV-PyMT; $C \mathrm{Cr}^{+/-}{ }^{-}$, and MMTV-PyMT; $C \mathrm{Cr}^{-/-}$mice. Mice were classified as having either $\leq$or $>0.1$ foci/

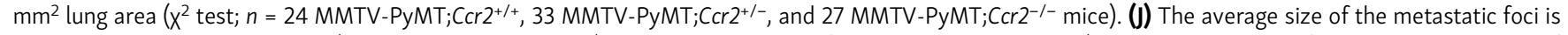
decreased in MMTV-PyMT; $C \mathrm{Cr} 2^{+/-}$and MMTV-PyMT;C $C r 2^{-/-}$mice compared with foci in MMTV-PyMT;Ccr2 $2^{+/+}$mice. The number of mice with an average of large versus small metastatic foci is indicated ( $x^{2}$ test; $n=24$ MMTV-PyMT;Ccr2 ${ }^{+/+}, 33$ MMTV-PyMT;C Cr2 $2^{+/-}$, and 27 MMTV-PyMT;Ccr2 $2^{-/-}$mice). Means \pm SEM are indicated. $\mathrm{P}$ values were determined by the tests indicated. ${ }^{*}, \mathrm{P}<0.05 ;{ }^{* *}, \mathrm{P}<0.01 ;{ }^{* * *}, \mathrm{P}<0.001$. N.S., nonsignificant. 


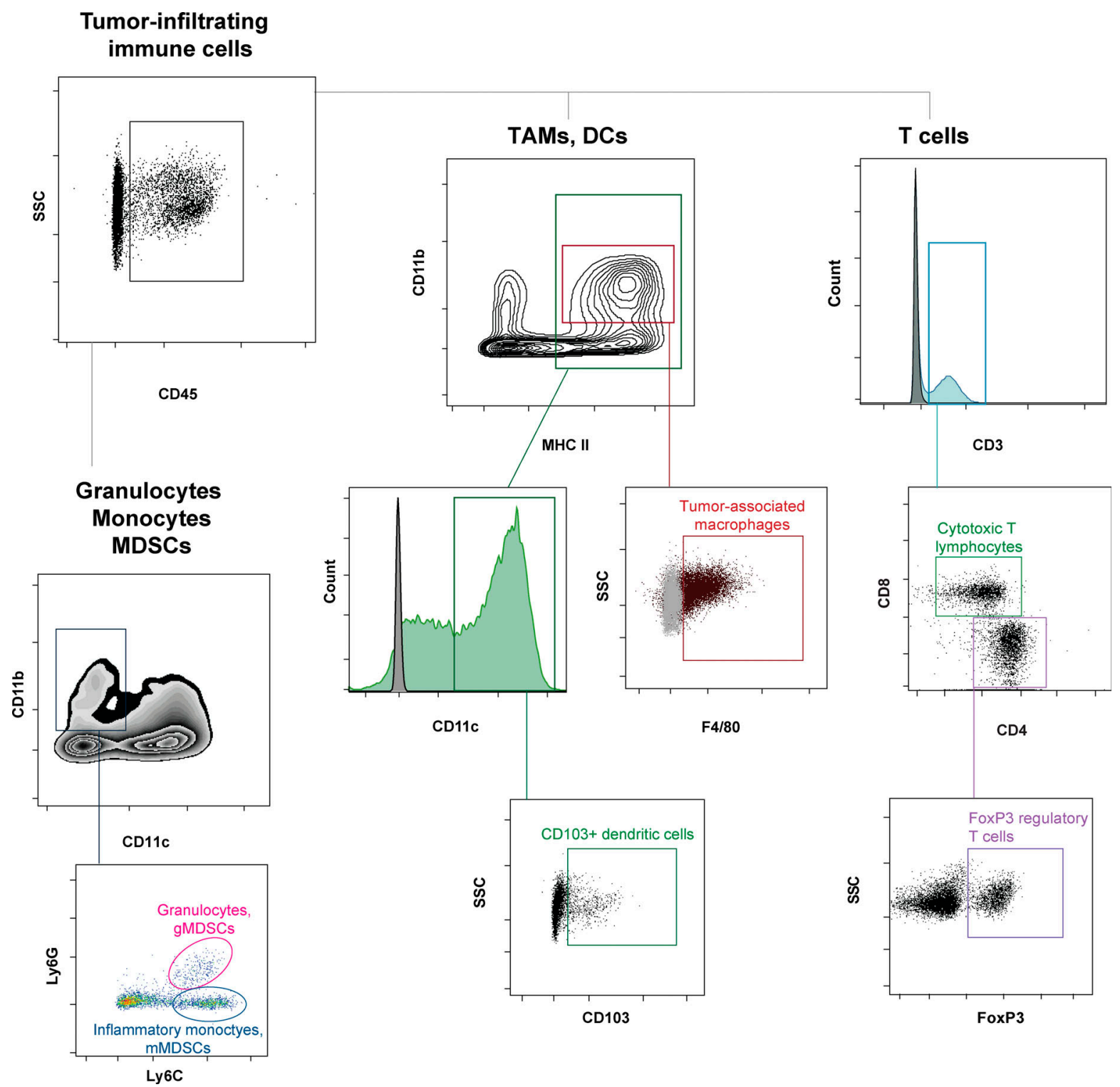

Figure S2. Gating strategy for immune cells. For flow cytometry analysis, single cells from tumors were gated on live CD45 cells and were further analyzed using the indicated markers to characterize infiltration of tumor-associated macrophages (TAMs), DCs, T cells, granulocytes, monocytes, and MDSCs. SSC, side scatter; gMDSC, granulocytic myeloid-derived suppressor cell; mMDSC, monocytic myeloid-derived suppressor cell. 
A

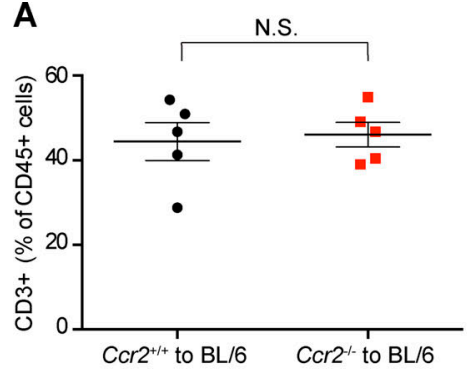

C

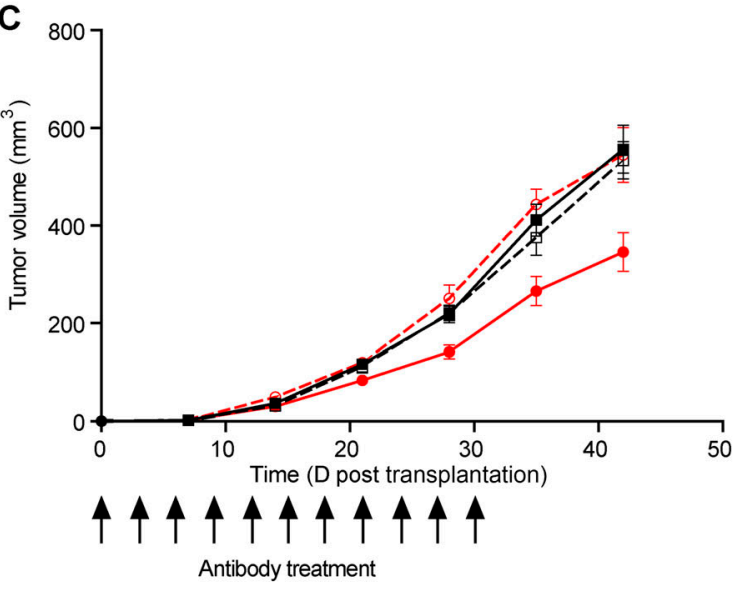

D

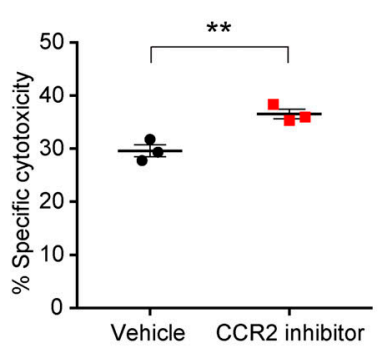

B

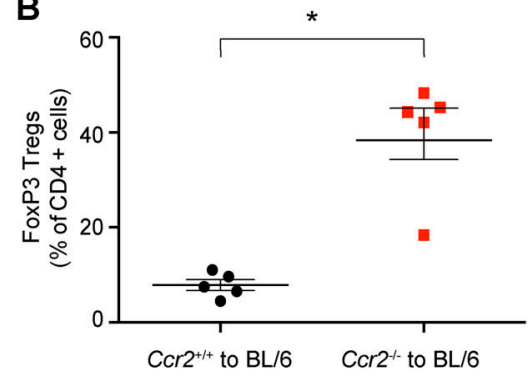

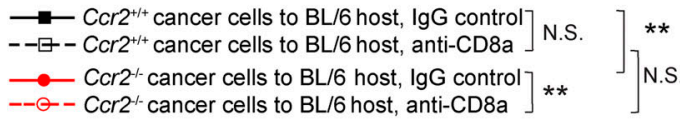

Figure S3. T cell infiltration in tumors derived from $\mathrm{Ccr2}^{+/+}$or $\mathbf{C c r 2} 2^{-/-}$cancer cells. (A) There is no difference between $\mathrm{Ccr2} 2^{+/+}$and $\mathrm{Ccr} 2^{-/-}$tumors during the growth-restricted phase in the percentage of $\mathrm{CD}^{+} \mathrm{T}$ cells among CD45 leukocytes, as determined by flow cytometry for $\mathrm{CD} 45^{+} \mathrm{CD} 3^{+}$cells $(n=5)$. (B) FoxP3 ${ }^{+} \mathrm{CD}^{+}$regulatory $\mathrm{T}$ cell infiltration is increased in $\mathrm{C} \mathrm{cr}^{+/+}$tumors compared with $\mathrm{Ccr}^{-1-}$ tumors during the growth-restricted phase, as determined by flow cytometry gated on $\mathrm{CD}_{4} 5^{+} \mathrm{CD} 3^{+} \mathrm{CD} 4^{+}$cells $(n=5)$. (C) Depletion of $\mathrm{CD} 8^{+} \mathrm{T}$ cells with anti-CD8a antibody significantly accelerated the growth of tumors from $\mathrm{CCr}^{-1-}$ cancer cells (arrows indicate treatment with antibody; $n=5$ for all conditions). (D) Pharmacological inhibition of CCR2 increased OT-1 T cell cytotoxicity toward E0771 cancer cells expressing OVA peptide, as measured by chromium $\left(\mathrm{Cr}^{51}\right)$ release (each dot is a triplicate from the same experiment, and similar results were obtained in an independently performed experiment). (E) Immune suppression induced by cancer cell CCR2 signaling is confined to the local tumor microenvironment. $\mathrm{Cr}^{+/+}$cancer cells transplanted into one mammary gland did not alter the growth of tumors from $\mathrm{Ccr} 2^{-/-}$cancer cells transplanted to the contralateral gland. Means \pm SEM are indicated. $P$ values were determined by Student's $t$ test $(A, B$, and $D)$. Tumor burden was determined by weekly caliper measurements ( $n=10$ for all conditions). Tumor volume was analyzed at the end time point by one-way ANOVA, followed by Sidak's multiple comparisons test (C) or by Welch's ANOVA followed by Dunnett's T3 multiple comparisons test (due to unequal variances; E). ${ }^{*}, \mathrm{P}<0.05 ;{ }^{* *}, \mathrm{P}<0.01$. N.S., nonsignificant. 
A

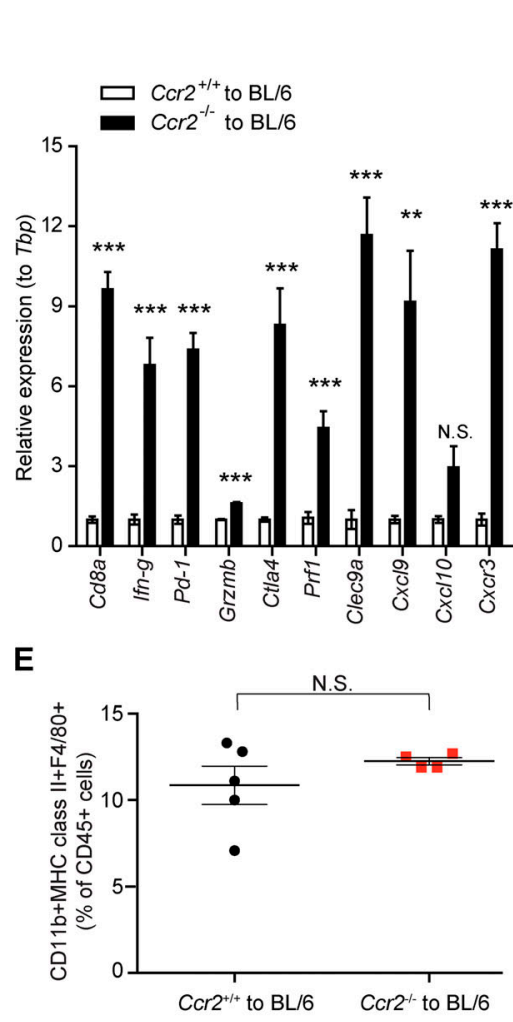

H

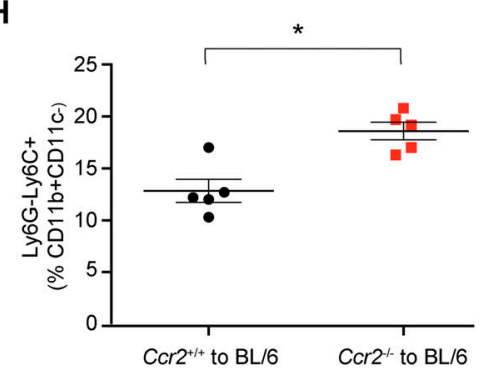

B
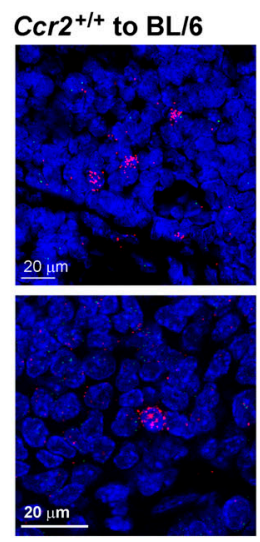

DAPI Ifn-g Cd8a
C
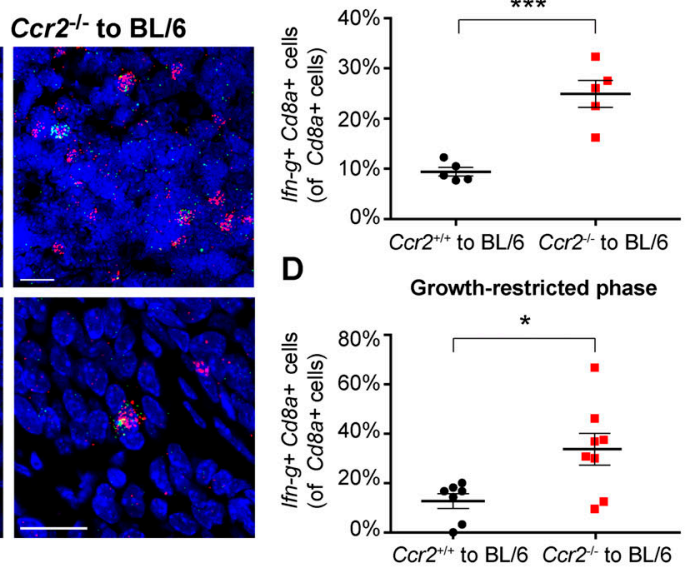

$\mathbf{F}$
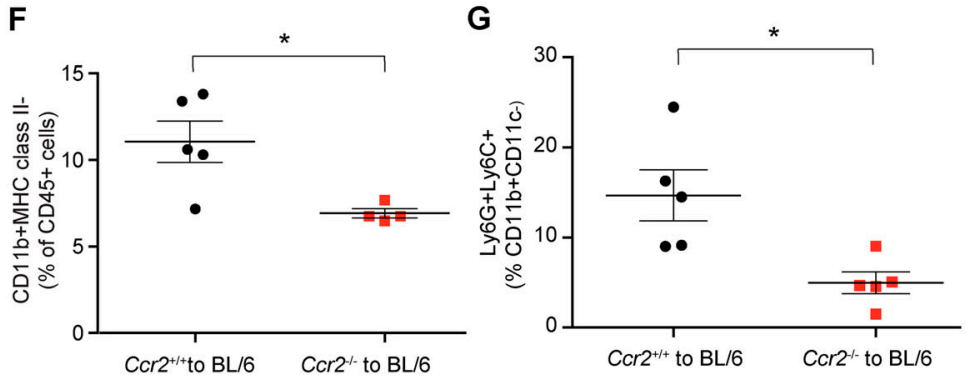

I

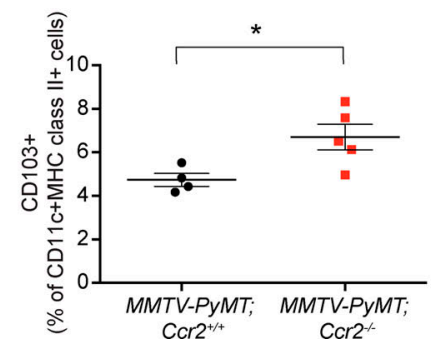

Figure S4. Myeloid cell infiltration in tumors derived from $\mathrm{Ccr2}^{+/+}$or $\mathrm{Ccr2}^{-/-}$cancer cells. (A) Tumors from transplanted $\mathrm{Ccr} 2^{-/-}$cancer cells have elevated markers of T cell infiltration and activation, including $C d 8$, Ifn-g, and Cxcl9 mRNA, compared with tumors from Ccr2 ${ }^{+/+}$cancer cells. RT-qPCR was performed on tumors from transplants of $\mathrm{Crr}^{+/+}$and $\mathrm{Ccr}^{-/-}$cancer cells isolated during the growth-restricted phase $\left(n=5\right.$ or 6 for $C \mathrm{cr} 2^{+/+}$tumors, and $n=6-8$ for $\mathrm{Crr}^{-1-}$ tumors). (B) Representative RNA FISH for Ifn-g (green) and Cd8a (red) probes in the early phase (3 wk; upper panels) and the late, growth-restricted phase (5-6 wk; bottom panels) of tumors from $\mathrm{Ccr}^{+/+}$and $\mathrm{Ccr}^{-/-}$transplanted cancer cells. Nuclei are counterstained with DAPI (blue; scale bar $\left.=20 \mu \mathrm{m}\right)$. (C and D) Quantification of RNA FISH shows more Ifn-g-expressing $C d 8^{+}$T cells in tumors from $\mathrm{Ccr}^{-/-}$cancer cells compared with $\mathrm{Ccr} 2^{+/+}$cancer cells at both early (C) and late, growth-restricted (D) phases (each dot represents the average of three to eight random fields of views of one tumor; $n=5$ tumors for early phase; $n=7$ or 8 tumors for late, growth-restricted phase). (E) Macrophage infiltration is unchanged between $\mathrm{Ccr}^{+/+}$and $\mathrm{Ccr2}^{-/-}$tumors during the growthrestricted phase, as determined by flow cytometry gated on $\mathrm{CD} 45^{+} \mathrm{CD} 11 \mathrm{~b}^{+} \mathrm{MHC}$ class $\mathrm{II}^{+} \mathrm{F} 4 / 80^{+}$cells $\left(n=5\right.$ and 4 for $\mathrm{Ccr2}{ }^{+/+}$and $\mathrm{Ccr} 2^{-/-}$tumors, respectively). (F) Percentage of $\mathrm{CD} 11 \mathrm{~b}^{+} \mathrm{MHC}$ class $\mathrm{II}^{-}$cells is reduced in $\mathrm{Crr}^{-/-}$tumors compared with $\mathrm{Ccr} 2^{+/+}$tumors during the growth-restricted phase, as determined by flow cytometry gated on $\mathrm{CD}_{4} 5^{+}$cells $\left(n=5\right.$ and 4 for $\mathrm{Cr} 2^{+/+}$and $\mathrm{Ccr}^{-/-}$tumors, respectively). (G) Granulocytes and granulocytic MDSCs are decreased on $\mathrm{Ccr}^{-/-}$tumors during the growth-restricted phase, as determined by flow cytometry gated on $\mathrm{CD} 45^{+} \mathrm{CD} 11 \mathrm{~b}^{+} \mathrm{CD} 11 \mathrm{c}^{-} \mathrm{Ly} 6 \mathrm{G}^{+} \mathrm{Ly} 6 \mathrm{C}^{+}$cells $(n=5)$. (H) Inflammatory monocytes and monocytic MDSCs are increased on $\mathrm{Ccr}^{-/-}$tumors during the growth-restricted phase, as determined by flow cytometry gated on

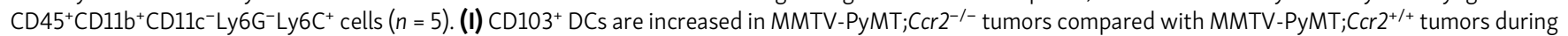
the growth-restricted phase, as determined by flow cytometry gated on $\mathrm{CD} 11 \mathrm{C}^{+} \mathrm{MHClI}{ }^{+}$cells within the $\mathrm{CD}_{4} 5^{+}$population $\left(n=4\right.$ and 5 for MMTV-PyMT; $\mathrm{Ccr} 2^{+/+}$ and MMTV-PyMT; $\left(\mathrm{Cr}^{-1-}\right.$ tumors, respectively). Means \pm SEM are indicated. $\mathrm{P}$ values were determined by Student's $t$ test. ${ }^{*}, \mathrm{P}<0.05{ }^{* *}, \mathrm{P}<0.01 ;{ }^{* * *}, \mathrm{P}<$ 0.001. N.S., nonsignificant. 
A

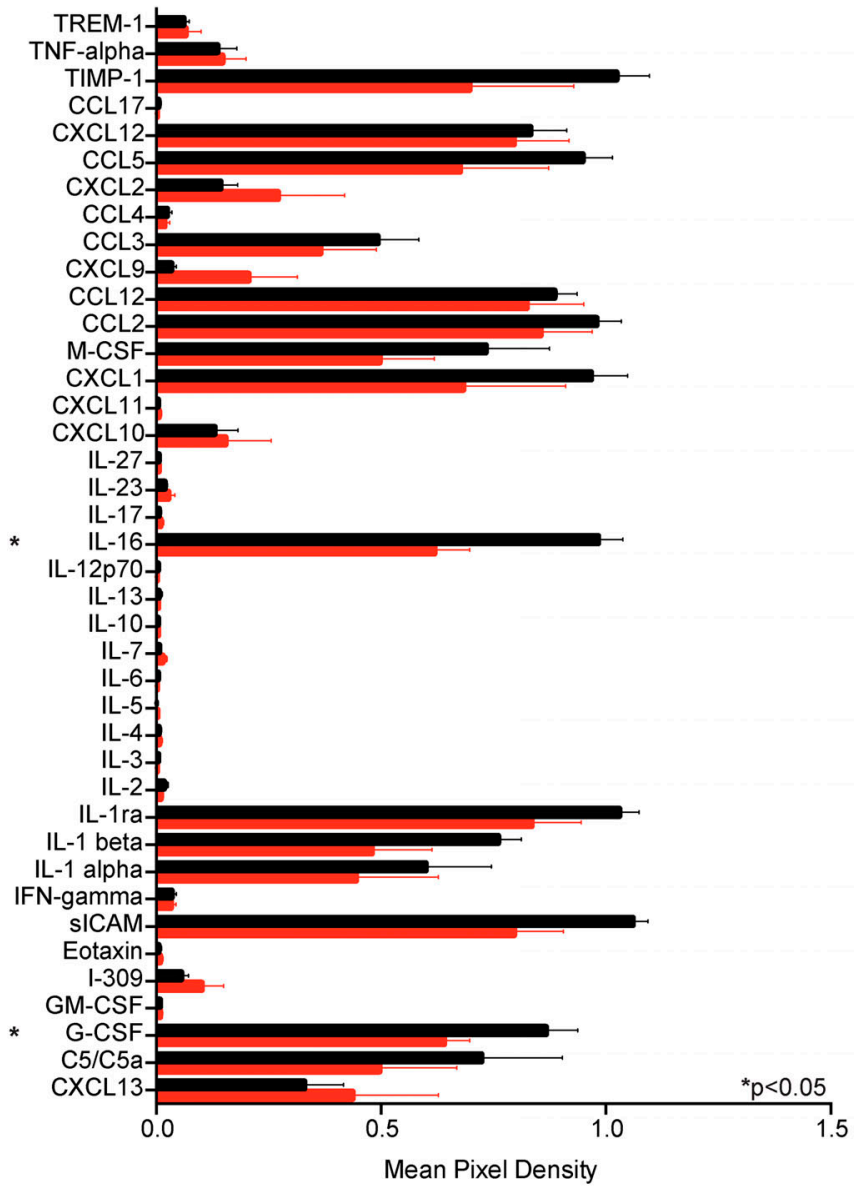

B

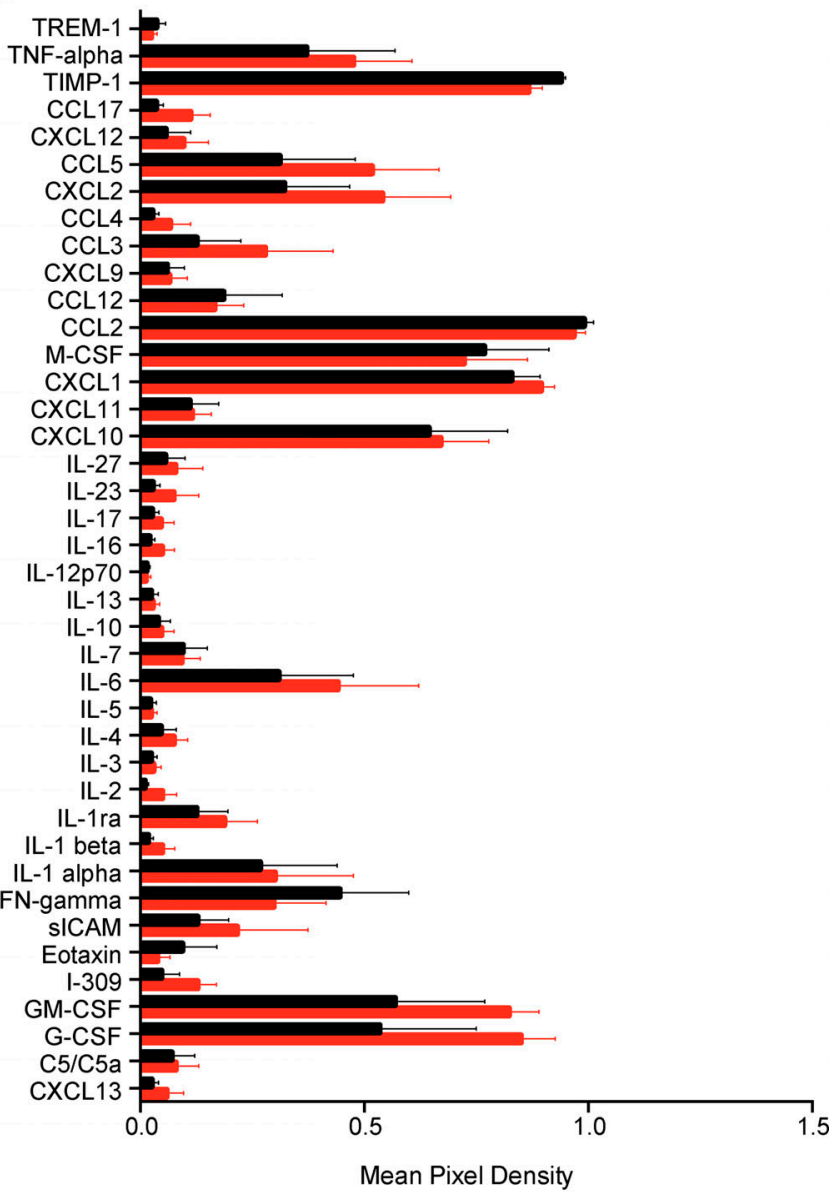

MMTV-PyMT;CCr2 ${ }^{+/+}$conditioned media MMTV-PyMT; $\mathrm{CCr}^{-/-}$conditioned media

Figure S5. Cytokine analysis in tumor lysate and conditioned medium. (A) Cytokine analysis from MMTV-PyMT;Ccr2 $2^{+/+}$and MMTV-PyMT;Ccr2 ${ }^{-/-}$tumors during growth-restricted phase, using the Proteome Profiler Mouse Cytokine Array Kit, Panel A $(n=4)$. (B) Cytokine analysis from supernatant of MMTV-PyMT; $\mathrm{CCr}^{+/+}$and MMTV-PyMT; $\mathrm{Cr}^{-/-}$cancer cells isolated during growth-restricted phase, using the Proteome Profiler Mouse Cytokine Array Kit, Panel A after serum starvation for $24 \mathrm{~h}(n=4)$. Means \pm SEM are indicated. P values were determined by multiple Student's $t$ tests. ${ }^{*}, P<0.05$. 